\title{
MANAGEMENT OF THE COMMUNITY ESTATE DURING AN INTACT MARRIAGE
}

\author{
J. ThOMAS OldhaM*
}

\section{INTRODUCTION}

The states of this country accept one of two very different marital property regimes. The common law system is based upon title; neither spouse has an interest in the property of the other, unless property is jointly owned. In contrast, community property systems accept the concept that spouses each have an equal, vested interest in all property accumulated, by either's effort, during marriage. The significance of these distinctions at dissolution has ebbed, however: All common law states now permit some type of property adjustment at dissolution, whether the dissolution is by divorce or death. The economic ramifications of divorce certainly are becoming more similar, regardless whether the marriage is dissolved in a common law or marital property state. ${ }^{1}$

\section{Copyright 191993 by Law and Contemporary Problems}

* Professor of Law and Law Foundation Scholar, University of Houston Law Center; Visiting Scholar, Wolfson College, Cambridge, and member of the Faculty of Law, Cambridge University, Lent and Easter Terms, 1992.

I would like to thank Chaille Cooper for her encouragement and support while I was writing this article. I would also like to thank Professor Mary Moers Wenig for her comments to an earlier draft, as well as Cheryl Crabbe and Tom Twedt, students at the University of Houston Law Center, for their able assistance in connection with the preparation of this article. Matthew Watson, a student at Duke Law School, also provided very useful editorial help. William Reppy, Jr., the editor of this symposium, made numerous suggestions and comments. This article was prepared while the author was supported by a Faculty Development Leave from the University of Houston.

1. At divorce, in some community property states, the community estate must be divided equally; in others, the court has the power to divide it equitably. See WILlIAM A. REPPY, JR. \& CYNTHIA A. SAMUEL, COMMUNITY PROPERTY IN THE UNITED STATES \$\$ 18-3 to 18-4 (3d ed. 1991). In all common law states, the divorce court has the power to divide some or all of the spouses' property equitably. See J. Thomas Oldham, DivorCe, SeParation AND the Distribution OF ProperTy § 3.03[1] (1992). Alimony (spousal support) is permitted in some circumstances in all common law states, and in all community property states except Texas. HOMER CLARK, THE LAW OF DOMESTIC RELATIONS IN THE UNITED STATES 620 n.14 (student ed. 1988).

Even though both common law states and community property states generally accept the notion of an equitable distribution of the marital estate, the economic consequences of divorce can differ when comparing the property divisions that might result in a common law state and a community property state. First, some common law states include all of the spouses' property in the pot of divisible property, not just property accumulated during marriage due to effort. See OLDHAM, supra, \& 3.03[2]. Among community property states, only Washington takes this approach. Id. \$3.03[5]. Also, common law states and community property states may apply the notion of equitable distribution in a different manner, even though the statutory factors set forth in the respective statutes are almost identical. Many studies find that housewives in a number of equitable distribution states frequently receive less than half the marital estate. LenOre J. WeITZMAN, The DivorCe ReVolution 108 (1985). But see Marsha Garrison, Good Intentions Gone Awry: The Impact of New York's Equitable Distribution Law on Divorce Outcomes, 57 BROOK. L. REV. 621, 674 (1991). In Texas, however, an equitable distribution community property state, 
In contrast, the two marital property systems operate quite differently in an intact marriage. In common law states, as long as no divorce action has been filed, property is managed by the owner. Under such a system, one spouse could have no power to manage any property accumulated during marriage, even if the property was acquired during marriage by the other spouse's effort. If the acquiring spouse is the record owner, that spouse can sell the property, or even give it away without the other's consent. ${ }^{2}$ In contrast, spouses in community property states are equal owners of all property acquired during marriage due to either's effort, regardless of title. Community property states have accepted for quite some time that the equal ownership principle imposes some limitations during marriage upon the management powers of one spouse.

Rules regarding the management of community property are only now being fully developed, in part because the rule of male management prevailed until the 1970s. Although the community property systems of that period accepted that both spouses had a vested, equal interest in community property accumulations as soon as they were acquired, the husband was considered the best "trustee" of the marital estate. No such gender-specific notions persist. This change, while undoubtedly increasing the power of women during marriage, has greatly complicated rules regarding management of the community estate. Should both spouses jointly manage all of the community, or should one spouse have the power to manage specific assets? If the latter, how will the identity of the managing spouse be determined and communicated to third parties? Also, if only one spouse is permitted to manage the community, must that spouse satisfy a standard of care when acting on behalf of the community?

This article surveys the systems that have been created in community property states to address the management of various types of community

housewives frequently receive more than half of the marital estate. In Texas, this could be attributed to the lack of postdivorce alimony, so property division rules have been adjusted. However, anecdotal evidence suggests that other equitable distribution community property states also seem inclined to compensate a spouse for career damage via a division of the community estate. See, e.g., McNabney v. McNabney, 782 P.2d 1291, 1296 (Nev. 1989).

At death, in a community property state, the survivor keeps $50 \%$ of the community estate, and the decedent may devise $50 \%$. See REPPY \& SAMUEL, supra, $\$ 19$. In a common law state, the survivor has a right to a fixed percentage (either $33 \%$ or $50 \%$ ) of the decedent's estate (including such assets as inheritances which would be separate assets in community property states), even if the decedent does not devise anything to the survivor. See J. Thomas Oldham, Should the Surviving Spouse's Forced Share Be Retained?, 38 CASE. W. RES. L. REV. 223, 224 (1987) [hereinafter Surviving Spouse].

2. See Sharon v. Sharon, 17 Fam. L. Rep. (BNA) 1280 (N.Y. Sup. Ct. 1991); Lawrence v. Lawrence, 394 S.E.2d 267 (N.C. Ct. App. 1990); Panhorst v. Panhorst, 390 S.E.2d 376, 379 (S.C. Ct. App. 1990). Of course, transfers made just before or after a divorce action is filed are subject to special scrutiny. See Miller v. Miller, 577 A2d 297, 299-300 (Conn. App. Ct. 1990); In re Frederick, 18 Fam. L. Rep. (BNA) 1008 (IIl. App. Ct. 1991); Hollander v. Hollander, 18 Fam. L. Rep. (BNA) 1027 (Md. Ct. Spec. App. 1991); Stroop v. Stroop, 394 S.E.2d 861, 863 (Va. Ct. App. 1990).

In the past, a spouse's dower or curtesy rights attached to all realty owned by the other spouse. See Richard H. Chused, Married Women's Property Law, 71 GEO. L.J. 1359, 1394 (1983). These rights have been abolished in almost all common law states and have been replaced by forced share statutes. See J. Thomas Oldham, Should the Surviving Spouse's Forced Share Be Retained?, 38 Case W. Res. L. Rev. 323 (1987). The homestead laws in some common law states restrict a spouse's ability to sell a home without the other's consent. 
property, and recommends an optimal management system. For example, it endorses the policy consensus that appears to be evolving that it is wise to require joint action by spouses in some but not all transactions, and suggests the types of transactions in which a joint action requirement would be prudent. This article also surveys the various problems that have arisen under the different management systems and discusses the questions that are presented if one spouse is permitted to act on behalf of the community. ${ }^{3}$ It also discusses whether allowing an investing spouse to decide whether to invest separate or community funds satisfies the duty that the manager has to the other spouse, ${ }^{4}$ and the wisdom and adequacy of remedies enabling one spouse to exercise this management power over community personal property if the other spouse is attempting to frustrate such efforts. ${ }^{5}$ Finally, this article considers how management rules governing gifts should be different from those governing sales. ${ }^{6}$

Although management issues arise both during an intact marriage and after the marriage has broken down, this article focuses upon issues arising in an intact marriage. ${ }^{7}$ The article considers a spouse's power to spend, sell, encumber, invest, or give away community property. A spouse's power to create contractual obligations, binding upon the community, will not be discussed.

\section{II}

\section{The Effect of Legal Rules upon the Actual Practices of Spouses IN MANAGEMENT OF THE COMMUNITY ESTATE}

Factors other than legal rules affect how spouses make decisions about the expenditure of marital funds. ${ }^{8}$ For example, a study ${ }^{9}$ of management decisions conducted two decades ago in England ${ }^{10}$ (a common law jurisdiction where, at

3. See infra notes $328-87$ and accompanying text. For example, this article considers whether a spouse should be liable for negligently managing the community.

4. See infra notes 396-403 and accompanying text.

5. See infra notes 80-121 and accompanying text.

6. See infra notes 238-74 and accompanying text.

7. By "intact marriage," I refer to those problems arising before the marriage has broken down, as witnessed by a separation of the spouses. (I do not consider whether any special management rules that may be necessary during separation before divorce should also apply when a marriage is breaking down but the spouses have not yet separated.)

8. For example, the Scottish Law Commission recently considered whether to recommend the acceptance of a community property system during marriage (as opposed to a deferred community of some sort). The Commission noted the large number of couples who already had informally agreed to share management power without any system of shared property rights. See ScOTrIsH LAW COMMISSION, FAMILY LAw 7 (Scottish Law Comm. No. 86, 1984).

9. J.E. TODD \& L.M. JONES, MATRIMONIAL PROPERTY, OFFICE OF POPULATION CENSUSES AND SURVEYS (GREAT BRITAIN) (Social Security Division, 1971).

10. The English studies discussed in this section are of particular interest as they arise in a country whose marital regime does not give a spouse a vested property interest in the other's accumulations during marriage. While studies of U.S. common law marital property jurisdictions would also be of interest, I know of none. Professor Garrison's recent study of divorcing couples, referred to infra in note 12, pertained to the economic consequences of divorce, not management during marriage. The study does give some information about whether divorcing spouses hold property jointly or only in the name 
least according to the law, a spouse has no vested property right in the other's accumulations during marriage ${ }^{11}$ ) found that more than fifty percent of all couples took title to their houses jointly. ${ }^{12}$ About forty percent of the couples had joint bank accounts. ${ }^{13}$

A 1983 English study by Jan Pahl of management decisions by spouses found that fifty-six percent of the couples studied pooled their funds. ${ }^{14}$ Additionally, in fourteen percent of the marriages, the wife had by spousal agreement sole management over marital funds, ${ }^{15}$ while in none of the marriages did the spouses agree that the husband alone should make all management decisions regarding marital funds. So, although the husbands in the sample generally made much more money than their spouses, ${ }^{16}$ and were therefore the legal owners and managers of that money, by private agreement the wife could manage funds earned by the husband in seventy percent of the marriages.

These two studies suggest that factors other than legal rules have a significant effect upon how spouses manage their money. ${ }^{17}$ This conclusion is supported by Pahl's findings regarding how management practices are changing without any change in the law. A few decades ago, one spouse almost always made

of one spouse.

11. TODD \& JONES, supra note 9 , at 10.

12. Professor Garrison found that almost $90 \%$ of all couples divorcing in 1984 in New York jointly owned their home. See Garrison, supra note 1, at 655. New York is also a common law jurisdiction.

Joint ownership might result from both spouses contributing to the purchase price, rather than an egalitarian decision to share ownership and management power of an asset bought by the earnings of one alone.

For those spouses who opt for "joint title" in a common law state, the power of one spouse to manage or convey depends upon title. A joint tenant or a tenant-in-common can unilaterally sell a part interest in the realty. If the spouses hold the property in a tenancy by the entireties, no interest can be sold without the consent of both spouses.

13. TODD \& JONES, supra note 9, at 14 . Unless the spouses' bank signature card provides otherwise, under a joint bank account either spouse may withdraw funds. Such an account is an "equal management" account under the terminology used in this article.

Perhaps it is not surprising that Professor Garrison found that divorcing spouses whose divorces seemed acrimonious were much less likely to have a joint bank account at the time of divorce than other divorcing spouses. See Garrison, supra note 1, at 655 (finding that $15 \%$ of spouses in "contested" cases-meaning those where divorce was sought on a fault ground-had a joint account, compared to $45 \%$ of other spouses).

14. JAN PAHL, MONEY AND MARRIAGE 78 (1989). Under these pooling systems, either spouse could choose to spend marital funds. Id. at 71 . These spouses, by private agreement, established what will be referred to herein as "equal management."

Pahl cautions that her "results come from couples who knew they were taking part in a study of financial matters and who chose to discuss this very sensitive aspect of marriage with an interviewer. It is likely that these samples were biased towards couples who were reasonably happily married and for whom money was not particularly problematic." Id. at 77.

15. Id. at 78. Under this system, referred to as "whole wage" by Pahl, either the wife would give the husband personal spending money or the husband would remove spending money before giving his pay to his wife. Id. at 67-68. The other couples managed their money either by the husband giving the wife an allowance, with the husband managing the remainder, or by giving each spouse sole management power over a certain separate amount of family funds.

16. Id. at 63-65.

17. Neither study establishes, of course, that legal rules have no effect upon how spouses manage their money. 
management decisions, and that spouse more often than not was the husband. ${ }^{18}$ The preceding paragraph summarizes her findings about how management norms have changed in a generation.

Even if one accepts that a number of factors other than legal rules affect how spouses manage marital funds, this does not render legal rules irrelevant. For example, one aspect of Pahl's study could support the argument that legal rules have some effect: In her study, Pahl attempted to learn more about how the couples made management decisions. She discovered that the manner in which the spouses said they managed their money did not accurately depict who really controlled important decisions. She found that in all marriages studied, even in those where the spouses pooled resources, one spouse controlled financial decisions. ${ }^{19}$ She therefore categorized the spouses into four types: marital resources controlled by the wife alone; marital resources controlled by the husband alone; pooled resources controlled by the wife; and pooled resources controlled by the husband. ${ }^{20}$ She found that when the wife earned more than thirty percent of what her husband earned, she was twice as likely to control the couple's finances. The following table summarizes Pahl's findings: ${ }^{21}$

18. Id. at 119. Pahl compares management practices of spouses in her sample to the management practices of their parents.

A U.S. study found that spouses' behavior regarding their property changed during the last century, without a change in the substantive law regarding marital property rights. This study analyzed probated estates of married testators living in a certain county in Pennsylvania. The authors found that in 1890 , less than $1 \%$ of married testators who owned a house had taken title jointly with his spouse. See generally Carole Shammas, MAR Ylynn SALMON \& MiChEl DaHLin, INHERITANCE IN AMERICA: From Colonial TIMES to tHE PRESENT 172 (1987). By 1920, the percentage had increased to $20 \%$. Almost fifty-five percent $(54.8 \%$ ) of spouses took title jointly in 1940 , and by $1960,80 \%$ took title jointly. Id.

19. Pahl was interested in determining who made the decision, rather than who administered it. She refers to the one who made the decision as the one who had "control" over the finances. Pahl, supra note 14 , at 57 . Although both spouses theoretically had the right to manage the property in the pooled account, she found that one spouse actually dominated. Id. at 87-91.

20. Pahl divided all couples with pooled resources into "wife controlled" or "husband controlled" categories. Those couples who said that both husband and wife controlled equally were placed into a "husband controlled" category. This was done "because couples where 'both' were said to control the money had financial arrangements, which, in many respects, resembled those of couples where the husband controlled the money more closely than those where the wife was in control." Id. at 87-88.

21. This table is based upon the table found in id. at $\mathbf{1 0 8 .}$ 


\section{RELATIONSHIP BETWEEN WIFE'S EARNINGS AND CONTROL}

Wife's Earnings

Management Type Over $30 \%$ of husband' ${ }^{a}$

Wife control

Wife-controlled pooling

Husband-controlled

pooling

Husband control

Totals
$6(21 \%)$

$12(43 \%)$

$5(18 \%)$

$5(18 \%)$

$28(100 \%)^{b}$
Wife's Earnings

Less than $30 \%$ of husband's ${ }^{\mathrm{a}}$

$8(11 \%)$

$15(20 \%)$

$34(46 \%)$

$17(23 \%)$

$74(100 \%)^{b}$

"Stated both in terms of the number of couples and the percentage of all couples of this type.

'In 28 couples, the wife earned more than $30 \%$ of the husband's earnings; in 74 couples she did not.

This table shows that when a wife earned less than thirty percent of what her husband earned, she controlled the household's finances thirty-one percent of the time. When she earned over thirty percent of what her husband earned, however, she had financial control sixty-four percent of the time. This strongly suggests that if the wife works and contributes a significant amount to the household budget, it is much more likely that she will have financial control.

The study does not establish what causes this increased level of control by the working wives. It could be attributed to Britain's legal rule that each wife "owns" those wages that she contributes to the household." Alternatively, the employment could raise her self-esteem so that she feels more able or entitled to participate in management of household funds. Also, women who make a substantial wage might be members of a group who are generally more assertive than others. ${ }^{23}$ It is reasonable to conclude from Pahl's study that, although legal rules may have some effect upon the manner in which spouses manage marital funds, it is likely that management patterns selected by spouses for their marriages can be substantially affected by considerations unrelated to legal rules.

22. Some spouses seem to have a strong intuitive feeling, inconsistent with community property theory, that money earned by that spouse's efforts is "theirs" and not their spouse's. For example, B.B. King expresses this view in a song: "As long as I'm paying the bills, baby, I'm paying the cost to be the boss." Riley B. ("B.B.") King, Paying the Cost to Be the Boss (MCA Records, 1968) (copyright Riley B. King).

23. Pahl did find that the wife's propensity to participate in financial management is affected by her general power to influence important family decisions. In those marriages where the wife makes most of the important decisions, it was much more likely that the wife would control the finances, most commonly through control of pooled resources. PAHL, supra note 14, at 175. 


\section{III}

\section{Rules Regarding Management PoWer}

\section{A. Overview}

The preceding section argued that legal rules are one of many factors that affect the way spouses manage the community estate. ${ }^{24}$ If legal rules do have some impact, what kind of rules should be adopted? One relevant concern pertains to how different management systems would affect commerce; this concern will be discussed below.

When considering an optimal management system, concerns other than facilitating commerce obviously come to mind. Many would agree that an optimal system should be based upon an assumption of gender equality. This assumption could be supported for a number of reasons. Many agree that gender equality is an important social value. Also, the community property system accepts the concept that each spouse owns a present, vested, fifty percent interest in each item of community property when it is acquired. This conceptual framework strongly suggests that neither spouse should be excluded from management. Certainly this is true of all other forms of co-ownership.

Jan Pahl's English study provides another reason why one might urge the adoption of a management system that encourages a wife to be an equal partner in management decisions affecting the community. In Pahl's study, she asked couples whether their marriage was very happy, happy, average, unhappy, or very unhappy. ${ }^{25}$ Of the spouses who pooled their funds, fewer than ten percent of the husbands and wives rated their marriage as average or worse. ${ }^{26}$ Of those who did not pool their funds where the wife controlled the marital funds, again fewer than ten percent rated their marriage as unhappy. ${ }^{27}$ In contrast, where there was no pooling and the husband controlled the marital funds, about forty percent of the wives and twenty-five percent of the husbands rated their marriages as average or worse. ${ }^{28}$ Although it is unclear whether there was a causal relationship between the exclusion of the wives from management and the lack of marital happiness, this information does provide additional support for the notion that it is wise for society to encourage both spouses to participate in management decisions. ${ }^{29}$

24. To the extent that a joint management system is accepted, this obviously will have at least a superficial effect upon many transactions.

25. Id. at 177 .

26. Id. at 176. This group included both "wife-controlled pooling" and "husband-controlled pooling" couples.

27. Id.

28. Id. at 177.

29. Id. This assumes that an appropriate interest of society is increasing marital happiness. 


\section{B. Some Implemented Management Systems}

Separate property is managed by the spouse who owns it. ${ }^{30}$ This is without question the best rule for management of separate property, as long as the separate property is not the homestead.

Turning to community property, after the demise of male management, three different systems have been utilized to allocate management power. ${ }^{31}$ One system requires spouses to act jointly regarding community property, and is customarily referred to as joint management. Another system, known as sole management, gives one spouse the sole power to manage particular community assets. The third system, called equal management, gives either spouse, acting alone, the power to manage the community.

Each system has its drawbacks. Joint management ensures that both owners will have the opportunity to participate in management of the community, ${ }^{32}$ but this requirement could place a substantial burden upon commerce, particularly if it were applied to all transactions involving any amount of community property. ${ }^{33}$ Furthermore, some spouses might not want to manage; the joint management system would burden them, unless some way of opting-out were created. Also, what should occur under such a system if only one spouse

30. See, e.g., TeX. Fam. Code ANN. $\$ 5.21$ (West 1975). During the nineteenth century, at least some states did not permit the wife to sell or encumber her separate property without the husband's consent. See William O. Huie, Commentary on the Community Property Law of Texas, 13 VernoN's Tex. Rev. Civ. Stat. 39 (1960); Kathleen E. Lazarou, Concealed under Petticoats: Married WOMEN'S PROPERTY AND THE LAW OF TEXAS 108 (1986); William O. Huie, Divided Management of Community Property in Texas, 5 TEX. TECH L. Rev. 623, 623 (1974); Susan W. Prager, The Persistence of Separate Property Concepts in California's Community Property System, 1849-1975, 24 UCLA L. REV. 1, 39 (1976).

31. See Max Rheinstein \& Mary Ann Glendon, Interspousal Relations, in 4 INTERNATIONAL ASSOCIATION OF LEGAL SCIENCE, INTERNATIONAL ENCYCLOPEDIA OF COMPARATIVE LAW ch. 4 (1980). Rheinstein and Glendon found that, in other countries accepting some form of community property, the law has retained male management (France and Spain), id. at 4-107-20, 4-80-87, or has accepted either equal management (Italy and Belgium), id. at 4-132-33, 4-129-30, or sole management (Quebec), id. at 4-130.

Quasi-community property is property acquired by a spouse while domiciled elsewhere that is treated like community property at dissolution of marriage because it would have been community property had it been acquired while domiciled in a community property state. See J. Thomas Oldham, Property Division in a Texas Divorce of a Migrant Spouse: Heads He Wins, Tails She Loses?, 19 Hous. L. REV. 1 (1981). Quasi-community statutes have been drafted as if the property would be treated like separate property until the marriage dissolves. See, e.g., TEX. FAM. CODE ANN. \& 3.63(b) (West 1975). Therefore, it would appear that quasi-community property is treated as the sole management property of the record owner. See Estate of Hanau, 730 S.W.2d 663 (Tex. 1987).

In most states, some limits upon male management of community property evolved before the demise of male management. For example, some types of transactions, such as gifts or the sale of community realty, required the consent of both spouses. See Prager, supra note 30, at 47-55; William R. Reppy, Retroactivity of the 1975 California Community Property Reforms, 48 S. CALIF. L. REV. 977, 1053 (1975).

32. Of course, even if both spouses participate, one spouse still could dominate the other. See STEPHEN EdGELl, MIDDle-Class Couples (1980); J. Ross Eshleman, THE FAMILY 429-36 (1985); PoWer IN FAMILIES (Ronald E. Cromwell \& David H. Olson, eds., 1975); PAHL, supra note 14, at 87-91.

33. For example, when Glendon and Rheinstein reviewed the many jurisdictions that had adopted some form of community property, none required the spouses to act together for all transactions involving community property. See Rheinstein \& Glendon, supra note 31, ch. 4. 
purports to transfer community property? There are possibilities other than that it is void $a b$ initio.

The sole management system clearly specifies who will have management power over each item of community property. However, if each spouse does not accumulate (or in some states have record ownership of) the same amount of property during marriage, this system would grant one spouse power over more than half of the community estate, even though both spouses possess a present, vested fifty percent interest. If one spouse works outside the home and the other does not, in many instances the spouse working in the home would manage little or no community property.

The equal management system, like the joint management system, reflects a general notion of equality; it does present a problem, however, if the spouses disagree, and especially if they give contradictory instructions to a third party. In addition, even though either spouse in theory may exercise management power, one might argue that the system facilitates the usurpation of management of the community by the dominant spouse..$^{34}$ Also, equal and sole management both permit one spouse to affect the property interests of the other without giving that spouse notice.

No state has accepted one of these management systems for all transactions involving community property. Each has adopted a combination of management rules, in which some transactions are governed by one set of rules, and others by another set. The next few sections discuss in more detail how each system works in practice, as well as the various problems that have been encountered in their implementation.

1. Joint Management. ${ }^{35}$ Joint management provides maximum protection to one spouse that his or her property rights will not be jeopardized without notice and consent. The concomitant cost of the system is its increased burden upon commercial transactions involving married people. This burden is of two types: first, logistical problems are created by requiring the approval of both spouses before a transaction can be completed; second, the system leaves open to challenge transactions that have been completed by one spouse where the other party did not know he was dealing with a married person, or where the party believed the married person was dealing with separate property (or sole or equal managment community property). In light of these burdens, in most states joint

34. Of course, either spouse could dominate the other, even under the joint management system.

35. Professors Reppy and Samuel refer to this system as "dual management." See REPPY \& SAMUEL, supra note $1, \S 14-1$.

In this article, the term "joint management" connotes action agreed to by both spouses. In some situations, the applicable statute requires joint action (e.g., both spouses to sign the document) as well. This phrase should not be confused with the term "joint" utilized in other property interests, such as a joint tenancy, where a holder of an interest may sell an interest in the property without obtaining the consent of all owners. Also, if one has a "joint" bank account, this normally means that either record owner may make a withdrawal; joint action is not needed. 
management is applied only to significant transactions whose structure would not be unduly burdened by the joint management requirement. ${ }^{36}$

Each state's joint management rule is somewhat different; some differ quite markedly. Wisconsin's joint management system pertains only to gifts of more than a "reasonable" amount of the community property, as well as transactions affecting the "homestead." 37 In contrast, the California joint management system covers gifts of any community personal property, ${ }^{38}$ the sale or encumbrance of all community property realty ${ }^{39}$ and of the furnishings, furniture, and other personal property used in the family home. ${ }^{40}$ Three states require spouses to act jointly in connection with either a purchase or a sale of community property real estate. ${ }^{41}$ Three states require joint management for the sale of a community property business. ${ }^{42}$ Two states appear to require the consent of both spouses for the sale of any asset of the community property business if both spouses participate in the management of the business. ${ }^{43}$

It is difficult to estimate with precision the degree to which transactions currently are impeded by the joint management rule, or would be impeded if additional types of transactions required joint management. No community property jurisdiction has ever attempted to make all transactions joint management transactions. ${ }^{44}$ It does seem reasonable to conclude, though, that some transactions would be more impeded by a joint management requirement than others. Some types of transactions are not usually conducted quickly or orally. For example, real estate transactions frequently are initiated by the signing of a real estate purchase contract but are followed by a hiatus during which the buyer inspects the property and reviews documents relating to title. Similarly, when a

36. Jurisdictions that have accepted some form of community property generally have restricted joint management to certain important transactions. They do not always agree, of course, regarding the types of transactions that should be subject to the joint management requirement. See Rheinstein \& Glendon, supra note 31, ch.4.

The Uniform Partnership Act has accepted a similar policy. Each partner generally is an agent for the partnership and may manage its affairs without the consent of the other partners (subject to an agreement to the contrary). Certain significant actions, such as a sale of the goodwill of the partnership, require unanimity, however. See U.P.A. \& 9 (1969).

37. For management rules regarding homestead, see WIS. STAT. ANN. $\$ 706.02$ (West 1981). Marital property held in the name of both spouses (other than that property held in "alternative" form) is also joint management property. Id. $\S 766.51$. The citations for the rules applicable to gifts can be found in note 240 infra.

38. Cal. Civ. Code $§ 5125$ (b) (West Supp. 1992). See also Nev. Rev. Stat. AnN. $\S 123.230$ (2) (Michie 1986); WASH. REV. CODE ANN. $\$ 26.16 .030(2)$ (West 1986).

39. Cal. Civ. Code \$ 5127. See also ARIz. ReV. STAT. ANN. \$ 25-214(c) (1991); Idaho CoDE \$ 32-912 (Supp. 1992); LA. CIV CODE ANN. art. 2347 (West 1985); NEV. REV. STAT. ANN. \$ 123.230(3); N.M. STAT. ANN. $\$ 40-3-13$ (Michie 1978); WASH. REV. CODE ANN. $\$ 26.16 .030(3)$.

40. Cal. Civ. Code $\$ 5125$ (c). See also LA. Civ. Code ANN. art. 2347; Nev. Rev. Stat. ANN. \$ $123.230(5)$.

41. See infra note 201.

42. LA. CIV. CODE ANN. art. 2347; NEv. REV. CODE ANN. \$ 123.230. Washington also apparently requires joint management in this situation. WASH. CODE $\$ 26.16 .030$. In California, the manager must give the other notice before such a sale. CAL. CrV. CODE $\S 5125$.

43. NEV. REV. CODE ANN. \& 123.230; WASH. REV. CODE ANN. $\$ 26.16 .030(6)$.

44. See Rheinstein \& Glendon, supra note 31 , ch. 4. 
business is sold, a purchase agreement is signed, and then various inspections occur and financial statements are prepared between that date and the closing date. A requirement that both spouses must consent in writing to such transactions at some time before the closing would not significantly impede them (assuming each spouse approves of the transaction). Still, complications could arise. For example, what should occur if one spouse, the sole owner of record, agrees to sell the property, representing either that he is not married or that the property is separate property, and the buyer relies upon this promise, only to learn later that the seller was married and the item was community property? ${ }^{45}$ Management problems would also arise if one spouse is sick or out of the country. Also, if "joint management" means both spouses must approve and sign all documents, including all changes to these documents, this will require spouses to attend a number of meetings regarding a transaction, and could be burdensome. One spouse's giving the other a power of attorney is a possible solution, but still a burden.

A much greater impediment on commerce would be imposed if every transaction involving community property, not just some transactions such as sales of community realty and sales of a community business, required joint action. ${ }^{46}$ For example, imagine what would occur if both spouses were required to go together to make every purchase. Similarly, many investment decisions, such as stock market sales, are quickly made; a requirement of joint consent could burden these transactions. ${ }^{47}$ For this reason, no state has accepted a general rule of joint management. ${ }^{48}$ States have attempted to carve out a set of transactions that generally involve substantial amounts of money (such as sales of community real estate or a community property business) or important items (such as household furnishings or clothing). In most instances, joint management has been applied only to these transactions.

Unfortunately, some states have deviated from this sensible general approach. In Texas, property acquired in any way other than those set forth in section

45. Problems such as this will be discussed below. See infra notes 158-91 and accompanying text.

46. The Scottish Law Commission mentioned this concern as one reason it chose not to recommend the adoption of a community property system for Scotland. See SCOTTISH LAW COMMISSION, supra note 8 , at 7 .

47. Suppose one spouse opened a brokerage account with a deposit of community property. If purchase and sale transactions were subject to joint management, the spouse would have to obtain the consent of the other to make investments; otherwise, the brokerage would be aware that it should not conduct trades without the consent of both spouses. It would make it significantly more cumbersome for brokers to make trades if investment decisions had to be confirmed with both spouses before action would be taken by the brokerage house. If oral approval were not sufficient, the burden increases even more.

48. The English Law Commission recently conducted a survey of the management systems in various jurisdictions. When reviewing the countries that had accepted community property, the Commission concluded that "[a]ll experience shows that a community system which does not permit independent management during marriage is unacceptable ...." ENGLISH LAW COMMISSION, FAMILY LAW-MATRIMONIAL PROPERTY 9 (English Law Comm. No. 175, 1988). The Commission found that all community property countries were moving toward more "independent" management of community property during marriage. Id. 
5.22(a) of the Texas Family Code is joint management property, ${ }^{49}$ as is property consisting of commingled accumulations by both spouses. ${ }^{50}$ There is no need to extend joint management to all such transactions. The Texas situation is undesirable in two respects. First, joint management is extended to some transactions where its protection is not needed. Second, joint management protection is not extended to transactions where it would be helpful, such as in sales of community realty (other than the homestead) or sales of a community business. The Texas Legislature should reconsider the rules regarding the scope of joint management. ${ }^{51}$

In addition to the Texas deviations mentioned above, a number of other states require all gifts of community property to be made jointly, regardless of the value of the gift. ${ }^{52}$ As discussed below, although it is apparent that gifts present different concerns than commercial transactions, it is unnecessary to extend joint management to gifts of a small amount of community property. ${ }^{53}$

When evaluating the importance of joint management rules, it would be useful to know how often spouses would-in the absence of a legal requirement-attempt to complete important transactions involving community property without informing the other spouse. Unfortunately, there are no studies on this point. A number of cases have been reported under joint management regimes where one spouse has unilaterally attempted to convey the community interest in realty, ${ }^{54}$ suggesting the problem is not uncommon.

If joint management were applied to all transactions involving community property, both spouses would receive prior notice of transactions affecting the community and could decide whether to consent. However, such a regime would impose many costs upon commercial transactions involving married people. These costs should be imposed only when a significant community concern is involved.

If the goal of the joint management system is to apply joint management to transactions that frequently involve a substantial amount of money, one could question whether the currently articulated scope of joint management is sensible. In many instances, a substantial portion of family wealth is in the form of

49. See Cockerham v. Cockerham, 527 S.W.2d 162, 169-71 (Tex. 1975). Spouses may agree to the contrary. TEX. FAM. CODE $\$ 5.22$ (West 1975).

50. TeX. Fam. Code ANn. § 5.22(b). See Brooks v. Sherry Lane Nat'l Bank, 788 S.W.2d 874, 876 (Tex. Ct. App.-Dallas 1990, no writ). Property accumulated by one spouse in a way set forth in \$ 5.22(a) is sole management property of that spouse, as long as it is not mixed with accumulations of the other spouse.

51. In fairness to the drafters of the Texas scheme, I should point out that it was adopted in 1967 , before the other community property states had revised their statutes regarding management of the community estate. See Joseph W. McKnight, A Retrospective Assessment of Texas Family Property Law Reform, 15 COMMUNITY PROP. J. 1, 3 (1988). Also, the drafters intended sole management to be the norm; courts have interpreted the statute in a different manner, creating a larger class of joint management property. Id.; Joseph W. McKnight, Texas Family Code Symposium, Title 1, Husband and Wife, 21 TEX. TECH L. REV. 911,1076 (1990).

52. See infra note 239 and accompanying text.

53. See infra notes 261-64 and accompanying text.

54. See infra notes $155-205$ and accompanying text. 
personalty. Current joint management legislation does not encompass personalty, except for gifts and transactions involving community property businesses or home furnishings. Still, transactions involving the conveyance of real estate or the sale of a business usually are not effected quickly, and therefore are not substantially burdened by the joint consent requirement. If joint management were extended to cover more transactions involving personalty, these transactions could be significantly burdened. This concern probably explains the California legislature's 1973 decision not to enact a bill requiring joint management for every transaction involving $\$ 1000$ or more of community funds. ${ }^{55}$

"Joint management" connotes that both spouses consent to the transaction. This consent could be established in a number of ways. Oral consent could be considered adequate. A requirement for written consent would be more burdensome, but would provide clearer evidence of consent. A number of states impose different rules for satisfying the joint consent requirement, depending upon what type of transaction is involved. In connection with the sale or encumbrance of community property, many states, including California, require both spouses to sign "any instrument" by which real estate is sold or encumbered. $^{56}$ In contrast, a California spouse managing a community (personal) property business, may unilaterally sell the business, but must give prior written notice to the other spouse before the sale. ${ }^{57}$ Nevada and Washington statutes require that if only one spouse participates in management of a community property business, that spouse unilaterally may sell assets of the business in the ordinary course of business. ${ }^{58}$ These statutes imply that the other spouse's consent is required for sales not in the ordinary course of business, but do not specify what is required to satisfy that requirement. Arizona and Louisiana have

55. See Prager, supra note 30, at 72. The California legislature refused to extend joint management to all transactions in 1987. See Carol S. Bruch, Protecting the Rights of Spouses in Intact Marriages: The 1987 California Community Property Reform and Why It Was So Hard to Get, 1990 WIS. L. REV. 731, 734.

If the decision is made to try to expand the types of transactions involving personalty that are subject to joint management, it would not be simple to specify which additional transactions should be subject to joint management. For example, a state could follow the policy reflected in the defeated 1973 California bill that transactions involving property worth more than a specified amount (in the California bill, $\$ 1000$ ) would be made subject to joint management. This approach is not well tailored to meet the needs of individual couples, however. For some spouses, $\$ 1000$ is a significant amount of the community estate; others would not consider that amount substantial. Also, continued inflation would gradually increase the burdens imposed by tying joint management to transactions involving a set dollar amount, unless the statute would be frequently updated. A more individualized approach would be to tie the joint management procedure to a transaction involving property worth more than a set percentage of the net value of the community estate. Although this second approach is more individualized, disputes undoubtedly could arise regarding the value of the estate. Also, creditors and other third parties would not know the value of the community estate and therefore would be unaware which transactions required the consent of both spouses.

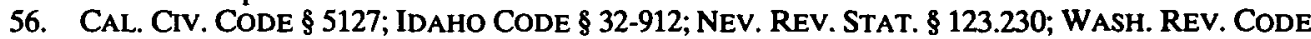
ANN. \$ 26.16.030.

57. CAL. CIV. CODE $\$ 5125$ (d). This is not really a joint management system, unless one perceives that merely giving a spouse notice is the sole purpose of joint management.

58. NEV. REV. STAT. ANN. \$ 123.230(6) (1992); WASH. REV. CODE ANN. \$ 26.16.030(6). 
a different approach: the same standard is applied to all joint management transactions. Arizona requires the "joinder" of both spouses. ${ }^{59}$ Louisiana requires the "concurrence" of both. ${ }^{60}$

Even if a transaction is considered sufficiently important to require joint management, it does not follow that both spouses must sign all documents relating to the transaction. It would suffice if both spouses are informed of the material terms of the transaction and approve of these terms. Indeed, that would seem to be the goal of joint management. No policy would be advanced by requiring spouses to sign all documents relating to the transaction. Also, both spouses should not have to approve nonmaterial changes in the terms of the agreement. Joint management rules should be fashioned so that both spouses are given the opportunity to review and approve the material terms of the transaction, while not establishing needless additional burdens upon commercial transactions involving married people.

The application of a joint management system to sales of community realty for which title is in one spouse's name apparently has not presented substantial problems. $^{61}$ This application ensures the participation of both spouses in some important decisions, apparently at no great cost. Also, it seems wise and not unduly burdensome to require joint action in connection with a sale of a community business or a gift of a significant amount of community property. However, any further extension of the joint management system would impose substantial additional costs. It therefore seems unwieldy to expand the joint management system to govern all community management decisions. Some other system must be created to govern those transactions not encompassed by the joint management system. To date, equal management and sole management (referred to as "independent" management by Jan $\mathrm{Pahl}^{62}$ ) systems have been proposed. They will be discussed below.

2. Sole Management. Sole management arises in different ways in different states. In Texas, a spouse has sole management power over certain types of

59. ARIZ. Rev. StAT. ANN. \& 25-214(c).

60. LA. CIv. CODE ANN. art. 2347.

61. Professor Reppy noted in a comment to the author that the California scheme has been in effect since 1917, and in his view it has not caused significant problems. If joint management is applied to sales of community realty titled in the name of one spouse, this would present the problem of what should occur when the record owner attempts to transfer the property without the other's consent. See infra notes 155-205 and accompanying text. (If title is in the name of both spouses, the buyer has notice of a need for joinder.)

The California real estate industry objected to a proposed enlargement of the management system to purchases of community realty. Among other things, concern focused upon the problem that the purchasing spouses do not prepare or sign the title document. See Bruch, supra note 55, at 742-43. It is unclear why this was perceived to be a problem; the seller normally conveys title to whomever the buyer directs. The title companies may have been concerned that they would incur additional liability or be required to conduct additional investigation if joint management would be extended to purchases. Three states do apply joint management rules to purchases as well as sales of community realty. See ARIZ. REV. Stat ANN. \& 25-214(c); Nev. ReV. Stat. ANN. \& 123.230(4); WASH. Rev. CODE ANN. \& 26.16.030.

62. See PAHL, supra note 14 , at 106. 
acquisitions enumerated in the Family $\operatorname{Code}^{63}$-most importantly, his or her earnings-as long as that spouse does not mix these acquisitions with acquisitions of the other spouse. ${ }^{64}$ In addition, a Texas spouse has the presumptive power to manage property if the spouse has record title, or if the spouse has possession and there is no title document. ${ }^{65}$

In Wisconsin, if title is in the name of one spouse, that spouse has the exclusive power to manage. ${ }^{66}$ This rule applies to personalty and realty, other than the homestead. New Mexico and Louisiana have adopted a similar system for personalty where one spouse has title. ${ }^{67}$

California, Louisiana, Nevada, and Washington have established sole management for community property businesses in some instances. In California, if one spouse "is operating or managing" a community property business, that spouse has sole management power. ${ }^{68}$ A "sole manager" of a Louisiana community property business has sole management power. ${ }^{69}$ In Nevada and Washington, where only one spouse "participates" in management of a community property business, that spouse has sole management power for transactions in the ordinary course of business. ${ }^{70}$ These statutes will be discussed below. ${ }^{71}$

The sole management system facilitates transactions for the family, in that one spouse can act for the community. Merchants and others do not have to worry about determining whether someone is married and, if so, about obtaining the consent of each spouse before completing a transaction. Also, if one believes that the law affects how couples behave, the system may minimize spousal disputes by specifying which spouse has the power to deal with various types of property. ${ }^{72}$

Critics of sole management would object, however, that this system deprives the nonmanaging spouse of control over the vested fifty percent interest he or she has in each item of the community. Feminist critics would note that under systems such as that in Texas, the nonmanager is normally the housewife, and that the system thereby reinforces a patriarchal power system in marriage. From this perspective, the equal management system is perceived to be more consistent with the philosophy of the community property system. This probably explains

63. TEX. FAM. CODE ANN. $\$ 5.22$ (West 1975).

64. See Brooks v. Sherry Lane Nat'l Bank, 788 S.W.2d 874, 876 (Tex. Ct. App.-Dallas 1990, no writ).

65. TEX. FAM. CODE ANN. \& 5.24(a).

66. WIS. STAT. ANN. \& 766.51(1) (West Supp. 1992). See also U.M.P.A. \& 5 (1987).

67. LA. CIV. CODE ANN. art. 2351 (West 1985); N.M. STAT. ANN. \& 40-3-14(B)(Michie 1978).

68. CAL. CIV. CODE \& 5125(d) (West Supp. 1992). The statute states that the spouse is the "primary" manager, which I believe means sole management.

69. LA. CIV. CODE ANN. art. 2350 (West 1985).

70. Nev. Rev. StAT. ANN. \& 123.230(6) (Michie 1986); WASh. ReV. CODE ANN. $\$ 26.16 .030(6)$ (West 1986).

71. See infra notes $\mathbf{1 2 8 - 3 6}$ and accompanying text.

72. The system could also create resentment by barring the nonmanaging spouse from asserting control over assets in which that spouse owned a $50 \%$ interest. 
why the equal management system has been accepted by all community property states except Texas as the system that generally governs transactions not subject to joint management. ${ }^{73}$

3. Equal Management. Under an equal management system, either spouse is entitled to manage community property. ${ }^{74}$ This system, like the sole management system, facilitates transactions involving married people. It also is consistent with the community property concept that each spouse is an owner of each item of the community as soon as it is acquired. ${ }^{75}$

The equal management system is not free of problems, however. Because both spouses concurrently possess management power, this approach can create marital discord. It might encourage a spouse to act preemptively. For example, if one spouse wants to sell an item of community property and the other does not, the spouse wishing to sell cannot be stopped, unless the other is willing and able to hide the item. ${ }^{76}$

Upon reflection, the potential for disputes should not be damning criticism of the equal management system. Disputes certainly could still arise regarding the use of community funds under the sole management system, even if, in theory, the law gives the nonmanager no "right" to manage. Indeed, disputes between spouses could arise under any management system. Equal management is more consistent with the joint ownership rights of the spouses than is sole management, however. Also, if one spouse is to be designated the sole manager, how would this spouse be selected? The Texas system, which permits the spouse who earns the property to be the manager, is inconsistent with contemporary notions of gender equality and partnership marriage. Equal management therefore seems preferable to sole management, at least in those situations where joint management does not apply. ${ }^{77}$

One might challenge whether any real difference exists between the sole management system and the equal management system. As long as joint action is not required, the significance of the legal rules regarding the mechanics of management by one spouse is not clear. Will the spouses learn of these rules, and if they do, will their behavior be affected? If the rule has some effect (and it seems likely that it does), a preference for equal management over sole

73. This is not true in a number of states regarding personalty where one spouse is the record owner. See supra notes $66,67$.

74. See ARIZ. Rev. Stat. ANN. \$25-214 (1991); CAL. Civ. CODE § 5125(a); IDAHo CODE § 32-912 (Supp. 1992); LA. Civ. Code ANN. art. 2346; NEV. Rev. STAT. ANN. § 123.230; N.M. STAT. ANN. § 40-314(A); WASH. REv. CODE ANN. § 26.16.030.

75. See generally Reppy, supra note 31, at 1054 (regarding how equal management is consistent with community property concepts).

76. As discussed below, if one spouse is irresponsibly dissipating community property, the other spouse can obtain a court order to attempt to mitigate the damage. Unless the spouse is irresponsibly dissipating the property, however, the only possible remedy is a partition of the community into two separate estates. See infra notes $124-27$ and accompanying text.

77. Cf. U.M.P.A. $\$ 5$ comment (1987). 
management seems inevitably to flow from the conceptual underpinnings of the community property system.

Third parties might be a bit nervous about an equal management system. For example, assume a spouse uses community property to purchase stock held by a broker. What should occur if one spouse calls the broker and orders the stock sold, and the other calls and orders the stock not sold? This problem must explain the enactment in some states of an exception to equal management for personalty titled in one spouse's name. ${ }^{78}$ However, this exception could be utilized by one spouse to undercut equal management significantly, particularly if there is no "add-a-name" remedy. ${ }^{79}$

a. Remedies to ensure equal management power. Under an equal management system, either spouse is entitled to manage community property. Some states that have accepted equal management have considered what should occur if one spouse frustrates the other's right to equal management. Two state legislatures have created remedies to facilitate the exercise of these management powers in some situations. ${ }^{80}$ Under these remedies, the spouse may petition the court to add the spouse's name to the title of the property in dispute, or otherwise facilitate access to the property by the complaining party ${ }^{81}$ A spouse does not have to allege that the other breached a specific management duty. The complaining spouse need only allege that the other is excluding the complainant from access to the community. ${ }^{82}$ These provisions obviously raise questions not otherwise presented by the acceptance of equal management. "Equal management" itself represents a largely hortatory communication to the public about a desired ideal. It makes no clear statement about what should occur if one spouse is not inclined to adhere to the ideal. ${ }^{83}$

Of course, most spouses presumably reach some accommodation about management of community funds blissfully unaware of any state statutes relating to the problem. The question arises whether any legal remedy is appropriate when spouses cannot reach some private agreement. There are a number of reasons why courts and legislatures might be reluctant to provide such a remedy.

78. See N.M. Stat. ANN. \& 40-3-14; LA. Civ. Code ANN. art. 2351; Wis. STAT. AnN. \& 766.51. In Texas, a third party without actual knowledge of the management power of the spouse he is dealing with may rely on title to determine management power. See TEX. FAM. CODE ANN. \$ 5.24. Indeed, in Texas possession is sufficient to trigger this right to rely, if there is no document of title. Id.

79. For a discussion of the "add-a-name" remedy, see infra notes 80-121 and accompanying text.

80. See Cal. Civ. Code $\$ 5125.1$; WIS. StaT. ANN. \$ 766.70. See also U.M.P.A. \$ 15 (1987); WASH. REV. CODE ANN. \$ 26.16.100.

81. CAL. Civ. CoDE $§ 5125.1$; WIS. STAT. ANN. § 766.70; U.M.P.A. \& 15. See also, Bruch, supra note 55, at 751-54; Carol Bruch, Management Powers and Duties under California's Community Property Laws: Recommendations for Reform, 34 HASTINGS L.J. 227, $279-81$ (1982).

82. See Bruch, supra note 55, at 753.

83. For example, even though the salary that a spouse receives during marriage is community property, the check is made out to the employee-spouse. If the employee-spouse then deposits the funds in an account in the name of that spouse alone, the other spouse will have no power over the funds. The agreement between the account holder and the bank normally will provide that only the account holder has the right to withdraw funds. 
First, many believe that if a couple cannot agree regarding the management of the community without judicial intervention, divorce is inevitable. ${ }^{84}$ Also, family disputes already demand substantial judicial attention; no one is anxious to do anything that could significantly increase the family law caseload. Finally, most agree that litigation between spouses is not a blueprint for family harmony and solidarity.

Courts in all states, including community property states, traditionally have refused to permit litigation between spouses in an intact marriage, particularly when the real defendant is not an insurance company. ${ }^{85}$ Among other matters, courts have been concerned that such litigation will disrupt family harmony. ${ }^{86}$ For example, if spouses have disagreed about whether the husband was adequately supporting the wife, ${ }^{87}$ or if the spouses could not agree about a child's education, ${ }^{88}$ courts have generally refused to become involved. This traditional reluctance to permit judicial resolution of disputes involving spouses is currently eroding, however. When one spouse has assaulted the other, an increasing number of courts have concluded that there is little family harmony left to disrupt, and spousal immunity has been abolished. ${ }^{89}$ Indeed, an increasing number of states have abolished spousal tort immunity, even for mere negligence. ${ }^{90}$ It is now not uncommon for a spousal tort suit to be joined with a divorce action. ${ }^{91}$ Still, management disputes present issues quite distinct from those involved in intentional tort cases. For example, maintaining family harmony would be a more significant concern in the former case. Although substantial animosity could result from a management dispute in an intact marriage, by definition the spouses are still cohabiting and are not contemplating divorce. This substantially differs from the situation where a spouse has committed an intentional tort (and it is, therefore, likely that the marriage has broken down).

84. A different view is offered in Marjorie M. Shultz, Contractual Ordering of Marriage: A New Model for State Policy, 70 CAL. L. Rev. 204, 325-28 (1982).

85. See Note, Litigation Between Husband and Wife, 79 HARv. L. REV. 1650 (1966). For example, in Miller v. Miller, 42 N.W. 641, 642 (Iowa 1889), the court stated that the judicial disinclination to hear family disputes "is of the genius of our laws, as well as of our civilization."

Although tort actions between spouses were not possible under the old common law, see William E. McCurdy, Torts between Persons in Domestic Relation, 43 HARV. L. REv. 1030, 1033 (1930), after the adoption of the Married Women's Property Acts, property disputes between spouses could be litigated during an intact marriage.

86. These concerns were discussed and rejected in Freehe v. Freehe, 500 P.2d 771, 774 (Wash. 1972).

87. McGuire v. McGuire, 59 N.W.2d 336, 342 (Neb. 1953); Austin v. Austin, 124 N.Y.2d 900 (N.Y. App. Div. 1953); Commonwealth v. George, 56 A.2d 228, 231 (Pa. 1948).

88. Kilgrow v. Kilgrow, 107 So.2d 885, 888-89 (Ala. 1958); People ex rel. Sisson v. Sisson, 2 N.E.2d 660,661 (N.Y. 1936); Hackett v. Hackett, 150 N.E.2d 431, 433-34 (Ohio Ct. App. 1958).

89. E.g. Bounds v. Caudle, 560 S.W.2d 925,927 (Tex. 1977). One might regard the erosion of the marital rape exemption as another example of this type.

90. See OLDHAM, supra note $1,88.01[3]$.

91. Id. \& 8.01[3][a]. 
Some commentators have criticized the traditional reluctance of courts to adjudicate disputes between spouses in an ongoing marriage. ${ }^{92} \mathrm{~A}$ few have argued that permitting judicial resolution of spousal disputes during an intact marriage will not, on balance, be detrimental to marriages. ${ }^{93}$ Some question the paternalism of refusing such a remedy. ${ }^{94}$ Others note that if a legal remedy is not provided, one spouse can still employ nonlegal methods to resolve a dispute, such as nagging, ceasing to perform household duties, withholding sex, threatening to separate, or committing violence; it is not clear that such disputeresolution methods are superior to judicial proceedings. ${ }^{95}$ Nevertheless, most courts have refused to become a "sounding board for domestic financial disagreements." article, wonder how often permitting an action to resolve management disputes would actually resolve the parties' problems.

California and Wisconsin have enacted statutes permitting a cohabiting spouse to petition a court to facilitate his or her exercise of management power over the marital estate where the other spouse is impeding the exercise of that power. ${ }^{97}$ This remedy is sometimes called the "add-a-name" remedy. Anecdotal evidence suggests that few spouses in California and Wisconsin have availed themselves of these remedies since they were enacted. ${ }^{98}$ In most instances, spouses involved in a management dispute either reach some accommodation privately or proceed directly to divorce court. However, some may wish to try to continue the marriage while allowing a third party to resolve the management dispute. For example, in $1971 \mathrm{Mr}$. Wilcox successfully sued his wife to assert his management power over community property, as set forth in the California statute then in effect. ${ }^{99}$ No divorce action was filed. It has been reported that the Wilcoxes were still married ten years later. ${ }^{100}$ This is one example of how it might be useful, in some instances, to provide a spouse with an alternate remedy that is less extreme than divorce when spouses have a dispute about management. As noted below, ${ }^{101}$ the existence of the add-a-name remedy could also facilitate negotiated solutions of management disputes, thereby avoiding the need to initiate legal proceedings. One therefore could argue that the add-a-name remedy may be quite useful, whether or not any litigation ensues.

92. Compare Shultz, supra note 84, at 319-25; Note, supra note 85; and Banks McDowell, Contracts in the Family, 45 B.U. L. REv. 43 (1965), with Austin v. Austin, 124 N.Y.S.2d 900, 902 (N.Y. App. Div. 1953); and Commonwealth v. George, 56 A.2d 228, 231 (Pa. 1948).

93. See e.g., Schultz, supra note 84, at 321; McDowell, supra note 92.

94. See e.g., Note, supra note 85 , at 1651.

95. See e.g., McDowell, supra note 92, at 60-61.

96. See e.g., Commonwealth v. George, 56 A.2d 228, 231 (Pa. 1948).

97. See supra note 80.

98. See Bruch, supra note 55. For example, Professor Melli of Wisconsin has informed the author that she knew of no reported case invoking the remedy. The add-a-name remedy has been invoked in at least one trial court case. See Letter from Professoir Melli to J. Thomas Oldham (March 18, 1992) (on file with author).

99. Wilcox v. Wilcox, 98 Cal. Rptr. 319 (Cal. Ct. App. 1971).

100. See Bruch, supra note 55 , at 740 n.25.

101. See infra text at note 103 . 
All available evidence suggests that most spouses are able to resolve management disputes during an intact marriage without judicial intervention, even when a remedy such as add-a-name is available. This suggests that judicial creation or statutory enactment of remedies will not impose great societal costs. Judicial caseloads will not be significantly affected, and spouses who wish judicial resolution of a management dispute, other than via a divorce, will be provided an arena for "limited warfare" to try to resolve their differences. ${ }^{102}$ The creation of the remedy could allow some spouses a final attempt at dispute resolution short of divorce. Even if few couples actually avail themselves of the remedy, its existence may encourage some recalcitrant spouses to obey the dictates of equal management. ${ }^{103}$ Some spouses could obtain the desired relief merely by threatening legal action. The add-a-name provisions also reflect a management model congruent with the philosophy of the community property system. So, although it is unlikely that many spouses will seek judicial resolution of a management dispute, the existence of the remedy could be useful.

The ability of a judge to craft an effective order to resolve a management dispute if the parties have not been able to resolve the matter privately is questionable. If one spouse is inclined to resist sharing management power, a court order seems an unlikely solution, at least if the goal is to help spouses reach a long-term solution to their management dispute and continue their marriage. ${ }^{104}$ At a minimum, a court should require parties to attempt to mediate such disputes before the matter comes before a judge. In addition, a petitioning spouse could also be required to file an affidavit to the effect that (1) counselling had been attempted and was unsuccessful or (2) the respondent spouse refused to participate in counselling.

The add-a-name remedy in some instances will facilitate joint management; in others, equal management will be created. For example, if both spouses become record owners of a car, in most instances a future buyer will require both to consent to its sale. ${ }^{105}$ In contrast, creating joint title to a bank account normally will permit either to withdraw funds.

California and Wisconsin have expressly adopted the add-a-name remedy. It is unclear whether other community property states would judicially create such a remedy if a spouse petitioned a court. In Wilcox $v$. Wilcox, ${ }^{106}$ a California court considered an analogous issue. At that time, the California statutes designated the husband as the sole manager of community personalty. The wife acquired some community personalty and would not deliver it to her husband. The husband initiated legal action against his wife to obtain control

102. This term is Carol Bruch's. See Bruch, supra note 55, at 739.

103. See Shultz, supra note 84, at 315-16; Bruch, supra note 55 , at $740,760 \mathrm{n} .92$.

104. The possible remedy of partitioning the community into two separate estates is discussed below. See infra notes 124-27 and accompanying text.

105. Professor Reppy notes that community personalty theoretically remains equal management property in a number of states, even if both spouses hold title. As a practical matter, however, joint action normally will be required by nervous buyers.

106. 98 Cal. Rptr. 319 (Cal. Ct. App. 1971). 
over the community property. Although there was no express statutory remedy, the court concluded that, because "for every wrong there is a remedy," the remedy sought by the husband could be granted. A spouse in a state other than California or Wisconsin who wished to enjoy equal management over the community estate would today be in a position similar to Mr. Wilcox. It would be sensible for courts in other states to fashion a remedy like add-a-name, even though no statute exists.

The add-a-name remedy permits a judge to fashion a remedy to attempt to ensure that the complaining spouse, in the future, will be able to exercise equal management. No damage award, based on denial of prior right of access, is allowed. Is this a sensible policy balance? Some might argue that if it is established that one spouse deprived another of his or her right to manage the community estate, damages should also be awarded.

The threat of a damage award could deter some spouses from frustrating the other's attempts to defeat equal management power, thereby advancing the purpose of equal management. However, a damage remedy could have other effects. The creation of a damage award could result in an undesirable incentive to bring such claims. Also, the damage remedy might cause the parties to be diverted from the principal goal of the action. Surely the goal should be to try to ensure that both spouses will be able to exercise equal management, while maintaining an environment conducive to the continuation of the marriage. The existence of a damage remedy might cause the parties to escalate the conflict. On balance, it seems wise not to permit a damage award in these actions.

In addition to the "add-a-name" remedy, California and Wisconsin permit a court to order "an accounting of the spouses' property and obligations." 107 A court also "may determine rights of ownership in ... and the classification of all property of the spouses." 108 It is unclear whether a spouse has an automatic right to an accounting. The applicable statutes provide that the court "may" order an accounting, ${ }^{109}$ but no standards are set forth regarding when an accounting is appropriate. This remedy was created to address situations where one spouse believes that the other spouse has not fully disclosed all property owned by the community. ${ }^{110}$

Although, at first glance, the accounting remedy seems appropriate, it could present some problems. In an accounting, the spouse is asked to list all property, and specify whether it is separate or community. ${ }^{111}$ It is not clear that spouses will be represented by independent counsel in such matters. It does seem possible that a spouse contemplating divorce could utilize an accounting as a

107. WIS. STAT. ANN. \& 766.70(2) (West Supp. 1992). The California provision is quite similar. See CAL. CIV. CODE $\$$ 5125.1(b) (West Supp. 1992).

108. WiS. STAT. ANN. \& 766.70(2). Again the California provision is quite similar. See CAL. CIV. CODE § 5125.1(b).

109. CAL. Civ. CODE $\S 5125.1$ (b); WIS. STAT. ANN. $\$ 766.70$ (2).

110. See Bruch, supra note 55 , at $738-39$.

111. The comment to Uniform Marital Property Act $\$ 15$ states that "the accounting would simply establish what is [community] property and what is not." U.M.P.A. $\$ 15$ (1983). 
means to obtain advantageous admissions from the other spouse regarding the character of property. ${ }^{112}$ The other spouse might not be too vigilant in scrutinizing such an accounting, being unaware that a divorce filing was imminent. ${ }^{113}$ If the spouse initiated the accounting to trap the other into making admissions regarding the character of property before obtaining legal advice, such behavior probably violates the duties spouses have to one another. This intention would not be easy to prove, however. It therefore would be desirable to establish that findings in such an accounting would not be admissible in a later dispute regarding the character of the property in a divorce proceeding, if both parties were not represented by independent counsel in the accounting.

The California accounting provision presents additional problems. It is not clear what remedies are possible in connection with an accounting. If a spouse breaches the fiduciary duty set forth in Civil Code section 5103, the remedy "shall include, but not be limited to, an award of 50 percent, or an amount equal to [the value of] fifty percent, of any asset undisclosed ... in breach of the fiduciary duty, plus attorneys fees."114 If the spouse were guilty of fraud, the minimum remedy is increased to one-hundred percent of the value of the property. ${ }^{115}$ These damages apparently may be sought in an action filed after the accounting is final; the most common forum presumably will be the divorce court.

Section 5103 of the Civil Code provides that the spouses are subject to the general rules governing fiduciary relationships. The provision also states that the spousal relationship is subject to the same rights and duties as apply to nonmarital business partners, and cites to sections 15019-15022 of the California Corporations Code. These provisions, which are derived from sections 19-22 of the Uniform Partnership Act, establish, among other things, a duty upon a partner to disclose true and full information of all things affecting the partnership. ${ }^{116}$ If a spouse does not disclose the existence of community property, the spouse, it seems, violates the duty to disclose. ${ }^{117}$ So the objecting spouse apparently may recover at least fifty percent (and possibly one-hundred percent)

112. See Bruch, supra note 55, at 738.

113. Arguably, a spouse should know all is not well when the spouses find themselves in court.

114. CAL. CIV. CODE \& 5125.1(g). In the opinion of the author of this article, any unintentional nondisclosure of property is a violation of this duty. The code language does not include the reference to value, but this must be what it means. The reference presumably is the "net" value (market value less all encumbrances). The statute does not so specify, but the award must become the separate property of the complaining spouse. The statute also does not clarify whether the award should come from the community or the separate property estate of the noncomplaining spouse. Logically, if the payor purports to pay such an award with community funds, the payor should receive credit only for $50 \%$ of each dollar paid, because the payee owned one-half of the community funds before the payment was made.

115. CAL. CIV. CODE $\$ 5125.1(\mathrm{~h})$. Again, the statute refers to "an amount equal to $100 \%$ " but must mean $100 \%$ of the net value.

116. CAL. CORP. CODE $\$ 15020$ (West 1991).

117. In any accounting, the examiner probably would ask each spouse to list all community property he or she knew existed. 
of the value of any property not disclosed, whether or not the objecting spouse incurred any financial loss, plus all attorneys' fees and costs.

A claim for breach of the section 5103 duty apparently can be made in a separate action filed after the accounting is final. The fifty percent recovery, plus attorneys' fees, seems recoverable even if the omission was unintentional or based upon an incorrect, good faith belief that the property was separate. In fact, the remedy seems mandatory, regardless of the equities of the situation. Such a remedy could prove to be an irresistible invitation to nonmanaging spouses in failing marriages. They may find it quite useful to initiate an accounting action before filing a petition for divorce. The accounting remedy, at least in its California incarnation, could prove undesirably to escalate divorce hostilities.

The accounting remedy puts the burden on the spouse lacking information to initiate an action to obtain information regarding the community estate. Another conceivable way to facilitate the exchange of information about community property would be to require each spouse to provide some form of disclosure, no more than once a year, to the other spouse. For example, the federal proxy rules, applicable to most large corporations, ${ }^{118}$ and the Revised Model Business Corporation $\mathrm{Act}^{119}$ require managers of corporations to provide information annually to shareholders about the company's assets, liabilities, and operations. However, the preparation of such a disclosure statement could be expensive for some couples. It is also not clear how a managing spouse could be notified that such a disclosure was required. Finally, studies suggest that most spouses do not hide financial information from each other. ${ }^{120}$ It makes sense to treat as exceptional the situation in which one spouse hides financial information from the other, and to require the spouse desiring the information to initiate the mandatory disclosure. ${ }^{121}$

b. Restricting equal management power. Two states, sensibly, do provide a means for a spouse to limit the management powers of the other when that spouse irresponsibly exercises management power. ${ }^{122}$ The Wisconsin provision permits a court, if it finds that "[community] property has been or is likely to be substantially injured by the other spouse's gross mismanagement, waste or absence," to terminate, temporarily or permanently, a spouse's management rights. ${ }^{123}$ Alternatively, the court may partition the community estate into two separate estates, delegate responsibility for past debts, and specify that future

118. See Robert W. HAMILTON, CORPORATIONS 628-43 (4th ed. 1990).

119. Rev. Model Bus. Corp. Act \& 16.20 (1985).

120. See generally PAHL, supra note 14.

121. This is the way the problem is handled under the Uniform Partnership Act. See U.P.A. $\$ \$ 19$, 20 (1981).

122. WIS. STAT. ANN. $\$ 766.70(4)$.

123. Id. $\$ 766.70(40)(\mathrm{a})(1)$. 
debts shall be solely the responsibility of the obligor spouse's property. ${ }^{124}$ Similarly, in Louisiana a complaining spouse may obtain a judgment decreeing the separation of property if the community is threatened by the fraud, neglect, fault, or incompetence of the other spouse. ${ }^{125}$

This type of remedy presents many of the same issues involved in the debate regarding whether spouses should be able to sue to realize their equal management rights. Most spouses who are unable to agree informally regarding management decisions presumably decide to divorce. However, some may wish to remain married, partition the community estate, and not accumulate community property or joint debts in the future. In all states, this remedy may be accomplished via a marital agreement. Judicial approval for contractually terminating the community regime is required only in Louisiana. ${ }^{126}$ Other couples might elect to resolve their differences with the help of a counselor or mediator.

If spouses are unable to agree regarding a partition of the community, and one spouse is dissipating the community or creating large debts, it seems wise to provide some means to limit the damage to the community. A court could, at a minimum, order the mismanaging spouse to transfer all remaining community property to the other, so the other would thereafter be the manager of all remaining community property. This judicial intervention still would not bar the spouse guilty of mismanagement from creating additional liability, thereby further diminishing the community. The Wisconsin provision permits the court to order that future debts may be satisfied out of the obligor's property only. However, it is unclear how creditors receive notice of this change in creditors' rights rules. ${ }^{127}$ In an attempt to minimize future dissipation, the court could enjoin the spouse abusing management power from incurring any liabilities other than those arising from normal living expenses.

c. The community property business. Although most community property states generally have adopted a system of equal management regarding community personalty, this rule does not apply in some states to community "businesses" 128 or "enterprises"129 in certain instances. In a number of states, it is accepted that, in some circumstances, one spouse should be the sole manager

124. Id. See also LA. Civ. CodE ANN. art. 2374 (West Supp. 1992); U.M.P.A. $\$ 15$ comment (1983). Some types of property are not subject to the Wisconsin remedy, such as partnership interests and shares in corporations that are not publically traded. See WIS. STAT. ANN. $\$ 766.70$.

125. LA. CIV. CODE ANN. art. 2374. Professor Reppy has advised the author that, in practice, this remedy is very difficult to obtain.

126. See generally REPPY \& SAMUEL, supra note 1, at 2-7. The Louisiana provision requiring judicial approval for abolishing the community appears at LA. CIV. CoDE ANN. art. 2329 (West 1985). Partition of the community estate does not require judicial approval. Id. art. 2336.

127. Article 2332 of the Louisiana Civil Code provides that an agreement effecting a partition of the community estate, or a judgment terminating the community regime, is effective as to future creditors if it is recorded in the parish where the property is located. LA. CIV. CODE ANN. art. 2332 (West 1985).

128. Cal. Civ. Code ANN. $\$ 5125$ (d) (West Supp. 1992).

129. LA. Civ. CODE ANN. art. 2350 (West 1985). 
of a community property proprietorship; different standards have been promulgated to determine under what circumstances sole management occurs. ${ }^{130}$ In California, if one spouse "is operating or managing" the business, that spouse is the sole manager. ${ }^{131}$ A Louisiana spouse has sole management power if the spouse is "sole manager" of the business. ${ }^{132}$ In Nevada and Washington, where only one spouse "participates" in management, that spouse has sole management power over transactions in the ordinary course of business. ${ }^{133}$ These provisions could present interesting issues regarding what constitutes a "business" or "enterprise" for purposes of the exception to equal management. ${ }^{134}$ In Nevada and Washington, disputes also will arise regarding whether a transaction was in the ordinary course of business. ${ }^{135}$ Confusion could also stem from the somewhat circular definition of whether one spouse has sole management power. All of these statutes essentially provide that sole management power is derived from the spouse assuming the role of sole manager. It will not always be clear when one spouse has sufficiently dominated the other in the management of the business to become sole manager. For example, if one spouse makes most of the management decisions, but the other provides some services, do these provisions apply? ${ }^{136}$ Similarly, does sole management apply if both spouses have been managers, but one spouse withdraws for a period?

It would be useful to try to determine the policy foundation for the sole management rule that now governs some community proprietorships. One explanation derives from creditors' rights rules. In those states that accept the "managerial" creditors' rights system, a creditor is able to levy only on all property managed by the obligor, regardless of whether the power is sole, joint, or equal management. ${ }^{137}$ So, by classifying the business as sole management property, in a managerial system the creditors of the nonmanager could not attach the community business. This could explain Nevada's acceptance of the sole management policy because, as a result, a creditor of one spouse cannot reach the sole-management community property of the other spouse. ${ }^{138}$ This

130. The Louisiana provision states that the spouse "has the exclusive right to alienate, encumber, or lease the movables" of the enterprise. See id. WASH. ReV. CODE ANN. $\$ 26.16 .030$ (West 1986) and NEV. REV. STAT. ANN. $\$ 123.230$ (Michie 1986) are similar. The California provision grants the spouse "primary management and control of the business." CAL. CIV. CODE ANN. § 5125(o) (West Supp. 1992).

131. CAL. CIV. CODE ANN. $\$ 5125(\mathrm{~d})$. The spouse is designated the "primary manager," but this appears to mean sole manager.

132. LA. Civ. CODE ANN. art. 2350.

133. Nev. ReV. Stat. ANN. \& 123.230(6); WASh. Rev. Code ANN. \& 26.16.030(6). These two statutes refer to the spouse's ability to sell or encumber assets of the business; they do not expressly provide that the spouse is the sole manager.

134. For example, if a spouse invests community funds in the stock market or real estate, is this a "business"?

135. See Pixton v. Silva, 534 P.2d 135, 138 (Wash. Ct. App. 1975).

136. See Reid v. Cramer, 603 P.2d 851 (Wash. Ct. App. 1979) (wife, serving only as bookkeeper for husband's business, estopped from denying contract and promissory note where she did not sign but expected to profit).

137. See REPPY \& SAMUEL, supra note $1, \$ \S 17-1$ to 17-3.

138. Id. 
is not true, however, in Washington, California, and Louisiana; a creditor of one spouse there may attach community property subject to the other spouse's sole management. ${ }^{139}$

The sole management exception to equal management for businesses may have been established due to a concern that the spouse normally not managing would attempt to harm the business when the marriage is breaking down. ${ }^{140}$ It is unclear why a spouse should be more inclined to destroy one type of community property rather than another. In addition, the spouse would be liable to the community for bad faith actions. ${ }^{141}$ Moreover, harmful actions when the marriage is breaking down could be avoided via a divorce court's restraining order, without creating an exception to equal management throughout the marriage.

A more persuasive explanation for the sole management policy is that experience normally is needed to manage a business successfully; if one spouse has been the manager, only that spouse has the necessary experience. From this perspective, the goal of sole management is to allow the community to avoid the cost of negligent decisions by an inexperienced spouse.

California, Louisiana, Nevada, and Washington accept the possibility that, if the spouses agree, both spouses may manage the business. The statutes of Nevada and Washington expressly refer to the possibility that both spouses might "participate" in the management. The same can be inferred from the California and Louisiana statutes. The result is less clear in these states if one spouse has been the manager and the other wants to start participating in the business, but the manager does not want to let the other spouse do so. If the other spouse arrives at the business and begins performing functions, it is unclear whether such conduct amounts to participation, thereby ending the manager's sole management powers. It would seem that the most sensible result in this situation would be to conclude that the spouse attempting to participate over the objections of the other spouse was not participating in management. This construction would advance the purpose of the sole management designation suggested above: to permit the community to avoid responsibility for unwise decisions by a spouse without much business experience.

139. Washington uses a community debt system, not a managerial system. The sole-management community business assets of the non-obligor spouse are liable for the debts of the other spouse made for a community purpose or to benefit the community. See id. $\$ 17-17$. The rules of California and Louisiana, while derived from the managerial model, do permit a creditor of one spouse to attach community property solely managed by the other. Id. $\$ 17-3$.

140. For example, a disgruntled spouse could sell an asset then essential to the business, fire employees, or sign a long-term employment agreement with a sibling. These acts probably give the other spouse a remedy for bad faith management, but this does not provide relief for fired employees (although they could be rehired by the spouse regularly managing the business). This article assumes a bad faith sale of a business asset to a third party is not voidable in those situations where equal management applies unless the buyer knew or should have known of the seller's bad faith management. Where sole management rules apply, the buyer takes the risk that the spouse with whom he is dealing lacks management power because the other is the sole manager (California and Louisiana) or has been the only spouse who participated in management (Washington and Nevada).

141. See infra notes $345-60$ and accompanying text. 
The add-a-name remedy applies to most community property. Wisconsin and California sensibly agree that it should not apply to partnerships and interests in professional corporations. ${ }^{142}$ These exclusions are wise; otherwise, the interests of the other principals could be affected. These principals chose to do business (or practice a profession) with one spouse, not the other. More surprisingly, Wisconsin and California also do not extend add-a-name remedies to a proprietorship, if the business has been operated by only one spouse. ${ }^{143}$ Unless one spouse can cut off the sole management power of the other merely by showing up at the business and trying to do things, this add-a-name limit suggests that a California spouse who has been the sole manager of a community property proprietorship has the right to decide whether to let the other begin to participate in the management of the business. This seems inconsistent with community property principles and advances no sensible policy. A more reasonable approach would be to permit an add-a-name remedy regarding a community property proprietorship, unless a judge determined that the petitioning spouse did not have the requisite training or experience to manage the business competently. In contrast to a partnership, granting an add-a-name remedy regarding a proprietorship does not affect the rights of any third party.

(1) The Community Property Corporation. In those states that do not normally restrict equal management rights for community property businesses, management power may be restricted due to the structure of the business. For example, assume a business is one-hundred percent community property and is organized as a corporation. In this circumstance, even though the business is community property, in some states one spouse will have no power to manage the business if shares are issued in the other's name. Community property stock is equal management property in five states, even if only one spouse has record title. ${ }^{144}$ In these states, either spouse could vote the shares for a slate of directors. In Louisiana, New Mexico, and Wisconsin, the spouse holding record title would be the manager, so only that spouse could vote. ${ }^{145}$

Authority to manage a corporation derives from corporate law. A corporation is managed by the board of directors; day-to-day matters are delegated to the officers. ${ }^{146}$ Even if shares of stock are subject to joint or equal managment, if only one spouse is elected president and the sole member of the board, that spouse will have the authority to manage the business.

142. Wis. Stat. ANn. $\$ 766.70(3)$ (West Supp. 1992); CAL. Crv. Code ANN. 8 5125.1(c) (West Supp. 1992).

143. Id.

144. California, Washington, Idaho, Arizona, Nevada.

145. See supra notes 66, 67 (regarding state-created exceptions to equal management for record owners of personalty).

146. See generally HARRY G. HENn \& JOHn R. AleXANDER, LAw OF CORPORATIONS 562-76 (3d ed. 1983). 
The add-a-name remedy is not available in Wisconsin for corporate stock that is not publicly traded. ${ }^{147}$ The rationale for this exclusion is more persuasive when there are other shareholders; if the corporation is one-hundred percent owned by the spouses, there is no reason to bar the add-a-name remedy absent a judicial finding that the spouse seeking relief lacks the expertise necessary to share management. For this reason, California's decision not to include this exception to add-a-name seems wiser, at least in those situations where the spouses own all the stock. ${ }^{148}$

(2) The Community Property Partnership Interest. The Uniform Partnership Act accepts the entity notion of partnerships, at least for some purposes; an interest in partnership is much like a share of stock. ${ }^{149}$ A partner's rights include (1) rights in partnership property, (2) an interest in the partnership, and (3) the right to participate in management. ${ }^{150}$

An interest in partnership may be community property, but the right to manage and the right to partnership property are not. ${ }^{151}$ The other partners have chosen to deal with one spouse, not the other or both. Therefore, only the chosen spouse can exercise management power, unless the other partners consent to the other spouse's participation, even if the interest is community property. ${ }^{152}$

A Louisiana statute provides that if only one spouse is a partner in a partnership, only that spouse has the power to "manage, alienate, encumber, or lease" the partnership interest, even if it is community property. ${ }^{153}$ This Louisiana provision is not surprising, in light of the Louisiana policy of giving the spouse holding record title of personalty sole management power. ${ }^{154}$ It is less clear whether a state that did not accept this title-based exception to equal management would consider a transfer to have occurred if the spouse, not the designated partner, attempted to alienate the partnership interest.

\section{Problems Arising from Joint Management}

a. One spouse attempting to purchase, sell, or encumber joint management property. In all states, sales or encumbrances of community realty are subject to

147. WIS. STAT. ANN. $\$ 766.70(3)(d)$.

148. E.g., CAL. CIV. CODE ANN. \& 5125.1.

149. See J. DENNIS Hynes, AGENCY AND PARTNERShIP 473 (3d ed. 1989); HAMILTON, supra note 118 , at 55 .

150. U.P.A. \& 24 (1981).

151. E.g., TEX. Rev. Civ. STAT. ANN. art. 6132b, $\$ 28$-A (West 1970).

152. For example, Mundy v. Mundy, 653 S.W.2d 954 (Tex. Ct. App. - Dallas 1983, no writ) held that a nonpartner spouse who received an assignment of part of a partnership interest pursuant to a divorce was entitled to a pro rata distribution, based upon the partnership interest, but did not have the right to participate in management. See also Temple v. White Lakes Plaza Assoc., 816 P.2d 399 (Kan. App. 1991) (same).

153. LA. Civ. Code ANN. art. 2352 (West 1985).

154. N.M. STAT. ANN. \$ 40-3-14 (Michie 1989) would have the same effect, if the partnership agreement provided that only the designated partner is empowered to sell the partnership interest. New Mexico also has enacted a title exception to equal management of community property. See id. A partnership interest is personalty, whether or not the partnership owns realty. U.P.A. \& 26 (1981). 
joint management rules, at least in some circumstances. In this context, it becomes important whether a transaction is considered a sale or other type of conveyance; a number of cases have involved this issue. ${ }^{155}$

All but two community property states require the consent of both spouses to sell or encumber community realty even if the realty is not the family home, ${ }^{156}$ and three require the consent of both to purchase community

155. See REPPY \& SAMUEL, supra note $1, \S \S 15-9$ to $15-10$.

156. TEX. ConST. art. XVI $\$ 50$ (only applicable to homestead); ARIZ. REV. STAT. ANN. § 25-214 (1991); CAL. Civ. Code ANN. \$ 5127 (West Supp. 1992); IdAHo CoDE § 32-912 (1983); LA. Civ. CODE ANN. art. 2347 (West 1985); NEV. REV. STAT. ANN. $\$ 123.230$ (Michie 1986); N.M. STAT. ANN. § 40-3-13 (Michie 1989); WASH. REV. CoDE ANN. \$ 26.16.030 (West 1986); WIS. STAT. ANN. \$ 766.51 (West Supp. 1992) (only applicable to homestead). The language used in each statute is a bit different. Some state that each spouse must "join in the execution of the deed or other instrument by which the real property is sold, conveyed, or encumbered." NEV. REV. STAT. ANN. \$123.230; WASH. REV. CODE ANN. \$ 26.16.030. The California, Idaho, and New Mexico provisions are quite similar. A New Mexico court has determined that "join" means "sign." See Hannah v. Tennant, 589 P.2d 1035 (N.M. 1979). The Arizona statute provides that "the joinder" of the spouses is required. ARIZ. REV. STAT. ANN. \$ 25-214. Louisiana requires the "concurrence" of both spouses. LA. CIV. CODE ANN. art. 2347. In Texas, homestead property may not be sold or encumbered without the "consent" of the other spouse. TEX. CONST. art. XVI, $\$ 50$. If there is no "instrument" to sign, the joinder requirement might not apply, even though title is affected. See Janes v. LeDeit, 39 Cal. Rptr. 559 (Cal. Ct. App. 1964)(community lost land under doctrine of tenancy by acquiescence due to actions, not involving writings, by husband alone).

These statutes do not apply if the community has an interest in a partnership or corporation that owns realty. See Attaway v. Stanolind Oil \& Gas Co., 232 F.2d 790 (10th Cir. 1956) (partnership); English v. Sanchez, 796 P.2d 236 (N.M. 1990) (corporation); Dotson v. Grice, 647 P.2d 409 (N.M. 1982) (partnership). Nevada and Washington statutes provide that a managing spouse may not sell realty or the goodwill of a community property business unless the transaction is in the ordinary course of business. NEV. REV. STAT. ANN. \$ 123.230; WASH. REV. CODE ANN. \$ 26.16.030. This clearly applies to a proprietorship community property business. The limitation probably also applies if a spouse conveys the goodwill of a corporation via a sale of stock, because the spouse individually would still be conveying the goodwill. However, if the realty or goodwill would be conveyed by the corporation via an asset sale, the other spouse's consent should not be required. The corporation, not the spouse, would be conveying the asset.

Most of these statutes also apply to the grant of a mortgage and lease for more than one year, and most apply only to "community property." See Neumann v. McMillan, 629 P.2d 1214, 1215 (Nev. 1981) (statute does not cover true joint tenancies). But one also applies to realty held by spouses as joint tenants or tenants in common. N.M. STAT. ANN. \$ 40-3-13. The Arizona statute extends to guarantees that would bind community property. ARIZ. REV. STAT. ANN. $\S 25-214$.

The statutes of all states but Texas describe the scope of joint management by listing the types of transactions covered. Texas does this by requiring sales or encumbrances of homestead to be effected jointly. TEX. FAM. Code ANN. \& 5.81 (West Supp. 1992). In addition, under Texas law property not acquired in one of the ways set forth in TEX. FAM. CODE ANN. $\$ 5.22(\mathrm{a})$ (West 1975) is joint management property, unless the parties otherwise agree. So, property other than homestead property (indeed, personalty as well as realty) can be joint management property in many situations. Id.; see also Cockerham v. Cockerham, 527 S.W.2d 162 (Tex. 1975). 
realty. ${ }^{157}$ In some circumstances, one spouse alone has attempted to consummate such a transaction, and courts have had to determine what should occur.

In Geronimo Hotel \& Lodge v. Putzi, ${ }^{158}$ the husband purported to lease community realty for five years. This transaction was subject to Arizona's joint management rules. Title was in the name of both spouses, so the lessee had notice of the wife's interest. The court held that the lease was voidable and, upon the wife's objection, would be declared void. However, the court said that, due to the express warranty of authority contained in the lease, the husband's separate estate was liable for the husband's breach of warranty of authority. The community was not liable for any such breach; otherwise, the court felt, the joint management system could be circumvented. ${ }^{159}$

Sims v. Craig ${ }^{160}$ also involved a situation where one spouse tried to convey an interest in community realty. Here a New Mexico husband signed an option contract with the plaintiff. However, the wife was out of the country, and the husband apparently had given the purchaser the impression that the wife would accept the terms of the offer. In reliance upon these representations, the plaintiff retained an architect to create drawings and incurred other expenses. The wife refused to agree to the terms of the option. The buyer then sued. The supreme court concluded that the option agreement was void because the wife had not signed. ${ }^{161}$ However, the court affirmed an award of damages to the buyer for negligent misrepresentation. ${ }^{162}$ The court did not clarify whether the plaintiff could attach only the husband's separate property.

In a more recent case, the New Mexico Supreme Court reiterated the rule that a contract of sale of community realty signed by only one spouse was void $^{163}$ and damages could not be recovered for nonperformance by the third

157. ARIZ. ReV. STAT. ANN. \$ 25-214; NEV. REV. STAt. ANN. \& 123.230; WASH. REV. CODE ANN. $\S 26.16 .030$. The Arizona provision requires the "joinder" of the spouses in a transaction for the acquisition of community realty. The Nevada and Washington provisions require the spouses to "join in the transaction of purchase or in the execution of the contract to purchase." It is not clear how spouses can "join" in a transaction without both being parties to the purchase agreement. The Nevada and Washington statutes both provide that statutory requirement may be satisfied either by both spouses signing or by "joining in the transaction of purchase," suggesting that alternative means of satisfying the statute exist. For example, this could occur if both participate in the negotiations, but only one signs the actual written offer. If this interpretation is correct, it is unclear how actively the nonsigning spouse would have to participate to satisfy the section. If the intention of the statute is to be sure that both spouses receive notice of the material terms of the transaction, few situations where both spouses did not sign the purchase documents should be considered as meeting the statutory requirements of joint participation.

158. 728 P.2d 1227 (Ariz. 1986).

159. Id. at 1230 .

160. 627 P.2d 875 (N.M. 1981).

161. Id. at 876 .

162. Id. at 877. Although the option was void, the spouse could be liable for tortious action in connection with its negotiation.

163. This is set forth in N.M. STAT. ANN. $\$ 40-3-13$. The distinction between void and voidable could be significant where one spouse purports to convey realty and the transaction closes. For example, if the conveyance is void, the purchaser is a trespasser who owes fair rental value to the community for the use of the property. Also, if crops are harvested by the buyer, they would belong to the community. 
party. ${ }^{164}$ As in Sims, however, the court held that an independent action could lie for misrepresentation, such as if the spouse misrepresented that the community realty was his separate property. ${ }^{165}$

In Andrade Development Co. v. Martin, ${ }^{166}$ a California husband signed a contract to sell community realty; the wife refused to sign. The contract prepared had a signature line for the wife, and the husband never represented that he had the authority, acting alone, to sell the realty. When the buyer sued, the court concluded that because the buyer knew the husband was married and the husband made no misrepresentation, no damages should be awarded. ${ }^{167}$

A Washington court held that a spouse can be liable for breach of contract if he acts alone in a transaction requiring both spouses' consent. ${ }^{168}$ The husband signed a contract to purchase land, a joint management transaction in Washington if the land is to be community property. The husband told the sellers he was married and made no misrepresentation. The court held that because only one spouse signed the promissory note and deed of trust, the obligation was a separate obligation of the husband, not a community liability. The sellers could sue the husband for the breach of the sales agreement, but the recovery could come only from his separate property. ${ }^{169}$

In Arizona, a guarantee must be signed by both spouses to bind the community. If but one spouse signs, only the separate estate of the signing spouse may be reached in the event of a breach. ${ }^{170}$

A somewhat different rule is applied in Louisiana. In Nicaud $v$. Fonte, ${ }^{171}$ only the husband signed a contract to sell community realty. When the wife objected, the court did not permit the buyer to recover damages or obtain specific performance. ${ }^{172}$ However, the court concluded that the husband should reimburse the plaintiff for all out-of-pocket costs. ${ }^{173}$

Another Louisiana case involved a loan transaction where the husband forged the wife's signature to grant a purported security interest in community

164. Arch., Ltd. v. Yu, 766 P.2d 911 (N.M. 1988).

165. Id. at 916. Cf. LA. Civ. CODE ANN. art. 2342 (West 1985) (providing that such a transfer would be valid, even if the representation was untrue).

166. 187 Cal. Rptr. 863 (Cal. Ct. App. 1982).

167. The court did suggest that damages would be recoverable had the husband made a misrepresentation. Id. at 868 . The court did not specify whether such a recovery would be limited to the separate estate of the spouse making the misrepresentation. See also Harper v. Raya, 201 Cal. Rptr.

563 (Cal. Ct. App. 1984) (holding damages would not be awarded where one spouse purported to grant

a life estate in community realty and buyer knew of the marriage).

168. Colorado National Bank of Denver v. Merlino, 668 P.2d 1304 (Wash. Ct. App. 1983).

169. Id. See also Smith v. Stout, 700 P.2d 343 (Wash. Ct. App. 1985) (holding that a signing spouse can be sued for damages where the other spouse does not consent to the transaction).

170. See Consolidated Roofing \& Supply Co. v. Grimm, 682 P.2d 457 (Ariz. Ct. App. 1984). See also Geronimo Hotel \& Lodge v. Putci, 728 P.2d 1227, 1227 (Ariz. 1986) (referring to Consolidated Roofing with approval).

171. 503 So.2d 79 (La. Ct. App. 1987).

172. In Lousiana, if only one spouse attempts to alienate community realty, the conveyance is a "relative nullity." LA. Civ. CODE ANN. art. 2353 (West 1985).

173. Nicaud, 503 So.2d at 83 . Here the wife did sign a listing agreement that apparently sanctioned a sale based upon the terms she later rejected. 
realty. ${ }^{174}$ The lender had no knowledge of the forgery, but the notary was its employee, and the notary recklessly notarized the signature of the wife, even though the wife had not signed the document in his presence. When the wife learned of the mortgage, she filed suit to avoid it. The court canceled the mortgage because both spouses did not sign. However, the court rejected the wife's argument that this debt was the husband's separate obligation under Civil Code Article 2363. Despite the holding that the mortgage was canceled, the creditor still could levy upon community assets, even the asset subject to the mortgage (unless barred by general exceptions precluding execution). ${ }^{175}$

Dynan v. Gallinatti ${ }^{176}$ held that a husband's attempt to mortgage household furnishings, a joint management transaction in California, is void. ${ }^{177}$ The husband borrowed money and gave the lender a chattel mortgage on the household furnishings; he forged the wife's signature on the documents.

Texas management rules regarding community realty differ significantly from those in all other community property states except Wisconsin. In Texas, a sale of community realty can be a sole management transaction, as long as the property is not homestead. ${ }^{178}$ Thus, a third party could reasonably believe that one spouse may unilaterally convey property, even if that party knew the property was community property. The Texas Family Code says that, if one spouse has title to property, it is presumed he or she has sole management power over it; a third party is entitled to rely on that spouse's sole management power, unless the third party knows the property is not sole management property. ${ }^{179}$

Washington ${ }^{180}$ and Louisiana ${ }^{181}$ also have adopted statutes that protect third parties who deal with a spouse who is the sole title-holder of community property. However, the protection afforded by Texas is probably broader than that provided by the other two states. In Washington and Louisiana, a third party cannot be a bona fide purchaser if the party is aware the property is community realty. In Texas, the person may rely on the authority of the spouse holding record title, as long as the person "does not have ... notice of the

174. Webb v. Pioneer Bank \& Trust, 530 So.2d 115 (La. Ct. App. 1988).

175. Id at 118.

176. 197 P.2d 391 (Cal. Ct. App. 1948). See also Neumann v. McMillan, 629 P.2d 1214 (Nev. 1981) (Nevada Supreme Court upheld the trial court ruling that nonsigning spouse could void a deed of trust affecting community realty where the deed of trust was signed only by the other spouse).

177. CAL. CIV. CODE ANN. \& 5125 (West Supp. 1992). If the encumbrance, granted by one spouse in violation of the joint management rules, is merely considered voidable this would, as a practical matter, eviscerate the joint management rule regarding encumbrances. If the encumbrance is considered voidable, to rescind the encumbrance the objecting spouse would have to repay the lender the amount lent when the encumbrance was created, thereby essentially enforcing the encumbrance. So a different rule was needed for an encumbrance. Uilateral gifts of community property and unilateral sales of community realty are voidable in California, not void.

178. See generally J. ThOMAS Oldham, TeXas Marital Property Rights 315 (2d ed. 1992).

179. TEX. FAM. CODE ANN. \& 5.24 (West 1975).

180. WASH. Rev. CODE ANN. $\$ 26.16 .095$ (West 1986). See also Cambell v. Sandy, 69 P.2d 808, 809 (Wash. 1937) (regarding what constitutes a bona fide purchaser).

181. La. Civ. CODE ANN. art. 2342 (West 1985); LA. Rev. Stat. ANN. 35:11 (West 1985 \& West Supp. 1992). 
spouse's lack of authority."182 Case law permits this reliance even if the third party knows the property is community property ${ }^{183}$ and even though both spouses previously had signed other recorded documents affecting the property. ${ }^{184}$

Without the benefit of an express statute, such as those in Texas, Washington, and Louisiana, New Mexico also has held that a third party buyer may rely on the spouse's authority to convey realty where the spouse holding record title purchased the property before marriage and the buyer has no reason to doubt the seller's authority. ${ }^{185}$

The Ninth Circuit, applying Idaho law, did not protect an innocent third party who dealt with a spouse holding record title. In United States v. McConkey, ${ }^{186}$ the husband borrowed money and signed a mortgage regarding community property. In connection with the loan, the husband signed an affidavit stating he was single. After both he and the wife had died, the wife's estate successfully challenged the validity of the lien. The court did not mention whether the lender had a cause of action for misrepresentation.

McConkey differs from Jeffers, the New Mexico case, in a few respects. In Jeffers, the spouse acquired title before marriage, while the husband in McConkey acquired title during marriage, which suggested community ownership. Also, Jeffers involved a sale of the realty, and McConkey involved a mortgage. When a court voids a mortgage, it is normally not as severe a remedy as a rescission of a sale of realty. If a mortgage is considered void, the lender still has a claim pursuant to the note. In many states the claim may be collected from community property. In contrast, if a realty sale is rescinded after the closing, the court then must determine whether to require the objecting spouse to pay the purchaser the amount given the other spouse at the closing.

If a spouse acquired realty before marriage, in states that characterize property according to "inception of title,"187 it would be reasonable to allow a buyer to rely on the acquisition date and assume that the property is the separate property of the spouse holding title. However, in those states that accept the

182. TEX. FAM. CODE ANN. § 5.24. For a discussion of the difference between "notice" and "knowledge" in this context, see H. Michael Bartley, Note, Community Property Subject to Joint Management of Both Spouses Cannot be Encumbered by one Spouse Acting Without the Other's Consent, 6 TEX. TECH L. REV. 1185, 1190 (1975).

183. See Fajkus v. First National Bank of Giddings, 735 S.W.2d 882, 886 (Tex. Ct. App.-Austin 1987 , reh'g denied March 2, 1988) (fact that both spouses signed for other transactions not sufficient to rebut presumption that husband sole manager).

184. See Thomas v. Rhodes, 701 S.W.2d 943 (Tex. App.-Fort Worth 1986), cert. denied, 480 U.S. 906 (1987). Where the spouse who is not the record owner is asked to sign the documents and refuses, one court has held that the third party is under a duty to investigate and can no longer rely on the presumption of section 5.24 of the Texas Family Code. Williams v. Portland State Bank, 514 S.W.2d 124 (Tex. Ct. Civ. App. -Beaumont 1974, error granted Feb. 2, 1975, dismissed March 3, 1975).

185. Jeffers v. Martinez, 601 P.2d 1204, 1206 (N.M. 1979) (spouse contended that before the sales contract was executed, the spouses had signed an unrecorded agreement transmuting the property into community property). In this article, for a spouse to "hold record title" or "hold title" means that only one spouse's name is on title.

186. 430 F.2d 652 (9th Cir. 1970).

187. See generally OLDHAM, supra note $1,87.02[2]$. 
"pro rata allocation rule" to acquisitions over time, ${ }^{188}$ a community contribution during marriage to mortgage payments for a house purchased before marriage thereby acquires a fractional interest in the property. Due to this community ownership interest, the property would then be subject to the joint management rules, at least as to the community share.

The third party might claim that, regardless of the time that the record owner acquired the property, it is appropriate to rely on a statement by the spouse holding record title that the property is separate property. If this argument is accepted, it could significantly undermine joint management protection, particularly if the argument would be accepted even if the property was presumptively community property. ${ }^{189}$ One court has rejected the argument that a third party may rely on such a statement by a spouse, ${ }^{190}$ however, Louisiana permits a buyer to rely on such a statement by the spouse holding title. ${ }^{191}$

A near consensus seems to have evolved that if (1) one spouse purports to convey realty acquired during marriage subject to joint management, (2) the buyer knows that the spouse acting as seller is married, and (3) the other spouse later objects to and successfully challenges the conveyance, the buyer cannot successfully sue the seller, as long as the seller made no misrepresentation to the buyer. However, joint management protection could be significantly weakened by two potential problems that stem from a unilateral transfer. First, when the transaction closes before the objecting spouse challenges the transaction, at least in California, the objecting spouse must refund the money provided by the buyer in connection with the rescission..$^{192}$ If the selling spouse has disappeared with or dissipated the funds received at the closing, the right to object would be of very limited utility if the objecting spouse must reimburse the buyer. It is difficult to decide which of these two innocent parties (the objecting spouse or the buyer) should bear the risk of this problem. If the transaction is considered void, the spouse objecting apparently would not have to refund the funds provided by the purchaser in connection with a rescission. ${ }^{193}$ However, if the sale is merely voidable, the objecting spouse would have to refund the consideration. ${ }^{194}$ Second, two states have held that a third party has a cause of action against a spouse who makes a misrepresentation in connection with a real estate transaction, where the other spouse later rescinds. ${ }^{195}$ In Arizona, damages based on such a claim apparently may be collected only from the separate estate of the spouse who made the misrepresentation; in New Mexico, which also allows

188. Id. \& 7.02[4].

189. For a discussion of the rules in the different states regarding what must be established to create the community presumption, see REPPY \& SAMUEL, supra note 1, \$\$ 4-1 to 4-5.

190. Arch, Ltd. v. Yu, 766 P.2d 911, 914 (N.M. 1988).

191. LA. Rev. StAt. ANN. 35 \& 11; LA. Civ. CODE ANN. art. 2342.

192. Mark v. Title Guarantee \& Trust Co., 9 P.2d 839, 844 (Cal. Ct. App. 1932).

193. See REPPY \& SAMUEL, supra note $1, \S 15-14$.

194. Id.

195. See supra notes $158-65$ and accompanying text. 
recovery, this issue has not been discussed. Unless the Arizona rule is accepted, joint management protection will be undermined. In most states, a third party normally may collect a tort judgment against one spouse from the community estate. $^{196}$ If a spouse misrepresents her authority to convey realty, and the transaction is voided by the other spouse, joint management protection, and the other spouse's right to object, would be significantly diluted if the community is still liable for a claim of misrepresentation when the other spouse voids the transaction.

In most states, encumbering community realty is a joint management transaction, but purchases are not. In these states, it therefore becomes important to determine whether a lien created in connection with a purchase is considered an "encumbrance" requiring the consent of both spouses. Liens that attached before the purchase, as well as liens created at the moment of acquisition, have not been considered such encumbrances. ${ }^{197}$ Professor Reppy has advised the author that a distinction has been made between a purchase money mortgage in favor of the seller and one in favor of a lender. ${ }^{198}$ The former has not been considered to require the consent of both, while the latter has been so considered. ${ }^{199}$ Such a technical distinction seems senseless and possibly unintended by the drafters of the joint management provisions. It probably explains why the New Mexico joint management provision expressly excludes purchase money mortgages. ${ }^{200}$

In three states, purchases of community realty are joint management transactions. ${ }^{201}$ These states will need to determine how to treat a purchase of realty by one spouse. Professor Cross has suggested that the purchase should presumptively be considered the separate property of the buying spouse, unless the contract or deed sets forth that the acquisition is to be community property. ${ }^{202}$ If the contract states that the purchase is community property, Professor Cross suggests that the objecting spouse should be able to rescind the transaction. $^{203}$ In Pixton $v$. Silva, ${ }^{204}$ the husband signed an agreement to purchase realty. The wife did not consent to the purchase; thus the transaction did not close. The court held that the plaintiffs could neither obtain specific performance of the contract nor recover the earnest money deposit. The court

196. See REPPY \& SAMUEL, supra note $1, \S 17$.

197. See King v. Uhlmann, 437 P.2d 928 (Ariz. 1968); Morgan v. Firestone Tire \& Rubber Co., 201 P.2d 976 (Idaho 1948)(lease from buyer to seller created at the same time as the closing was not such an encumbrance).

198. Telephone Conversation with Professor William A. Reppy, Jr., Professor of Law, Duke University (Sept. 1992) [hereinafter Conversation with Professor Reppy].

199. See, e.g., Davidson v. Click, 249 P. 100 (N.M. 1926) (lien in favor of seller signed at the closing by the purchaser did not require the consent of the other spouse).

200. N.M. STAT. ANN. \& 40-3-13 (Michie 1978).

201. ARIz. REV. STAT. ANN. § 25-214 (1991); Nev. REV. Stat. ANN. § 123.230 (Michie 1986); WASH. REV. CODE $\S 26.16 .030$ (West 1986).

202. Harry M. Cross, Equality for Spouses in Washington Community Property Law-1972 Statutory Changes, 48 WASH. L. REV. 527, 534-37 (1973).

203. Id.

204. 534 P.2d 135 (Wash. Ct. App. 1975). 
did not discuss whether the husband's separate estate should be liable, a remedy Professors Reppy and Samuel endorse in this situation. ${ }^{205}$

(1) The Action to Rescind. If both spouses do not join in the transaction affecting the realty, the transaction is "voidable" in most states and "void" in others. This distinction can be significant. If the transaction is "void," even the signing spouse or a third-party participant may decide to rescind. ${ }^{206}$ Voidable transactions, on the other hand, may be challenged only by the nonsigning spouse $^{207}$ and are effective until challenged. For example, if a third party obtained a judgment against the signing spouse after the purported transfer, a judgment lien would not attach to the realty unless the nonsigning spouse voided the transfer. ${ }^{208}$ Also, if a sale of community realty is voidable, the record owner keeps all rents and owes taxes until the action to avoid is brought. In contrast, if the transaction is void, the spouses should owe taxes and be entitled to the rents.

The distinction between a void and voidable conveyance may also determine whether the spouse attempting to avoid a unilateral sale of community realty must refund the consideration given by the buyer to the other spouse. For example, in Mark v. Title Guarantee \& Trust $\mathrm{Co}^{209}$ the husband unilaterally sold community realty, representing to the buyer that he was unmarried. (In California, the sale by one spouse of community property is voidable, not void. ${ }^{210}$ ) When the wife sued to rescind after the closing, the court required her to reimburse the buyer for consideration given to the other spouse.

Few courts have considered at what point the objecting spouse must challenge the transaction to invalidate it when the transaction is considered voidable rather than void. For example, one could imagine situations where one spouse would sell or encumber community realty without the knowledge or consent of the other spouse. The buyer might then take various actions in reliance on the transaction. California law requires a nonconsenting spouse to take such action within one year of the recording of the transaction, if record title was in the name of the transferor only. ${ }^{211}$ In other states, the statute of limitations presumably begins to run when the objecting spouse learns of the transaction.

(2) Estoppel and Ratification. If both spouses do not give written consent to a joint management transaction, the transaction can, in some states, be

205. REPPY \& SAMUEL, supra note $1,815-15$.

206. See Hannah v. Tennant, 589 P.2d 1035 (N.M. 1979). Cf. Tew v. Man Waring, 480 P.2d 896 (Idaho 1971) (Failure of one spouse to sign may make the transaction void, but this rule is not followed when both spouses perform their part of the bargain.).

207. Ganther v. Johnson, 79 Cal. Rptr. 381, 386 (Cal. Ct. App. 1969); Tombari v. Griepp, 350 P.2d 452,454 (Wash. 1960).

208. See In re Lemons \& Assoc., 69 B.R. 360, 363-64 (Bankr. D. Nev. 1987).

209. 9 P.2d 839 (Cal. Dist. App. Ct. 1932).

210. See generally REPPY \& SAMUEL, supra note $1, \S 15-14$.

211. See CAL. CIV. CODE $\$ 5127$ (West Supp. 1992). This may not be true if the objecting spouse did not know of the transaction and the transferee knew the transferor was married. See Byrd v. Blanton, 197 Cal. Rptr. 190, 193-94 (Cal. Ct. App. 1983). 
validated by other evidence. For example, that the nonsigning spouse consented or that one spouse ratified an initially unauthorized act by the other spouse. Alternatively, in all states, a nonsigning spouse may apparently be estopped to rescind or assert as void a unilateral action by the other spouse.

Most states accept as sufficient the informal approval by one spouse of a gift of community property by the other; written approval is not required. ${ }^{212}$ This is not surprising in those states where the applicable statute says that implied consent is sufficient. ${ }^{213}$ The joint management statutes for transactions involving realty are different, however. Four states, including Washington, expressly require both spouses to sign the documents conveying or encumbering the property. ${ }^{214}$ In other community property states, both spouses must "join" in the transaction, ${ }^{215}$ while Louisiana requires the "concurrence" of both spouses. $^{216}$

It would appear clear that the oral consent of a spouse should not satisfy the joint management rule regarding realty, at least in those four states where the statute requires both spouses to sign the appropriate documents. ${ }^{217}$ In another context, a California court has concluded that oral consent to a gift of community property is not sufficient to satisfy the requirement of the statute that both spouses consent in writing to a gift of community property. ${ }^{218}$ Somewhat surprisingly, Washington courts have reached a different conclusion despite the language of its statute governing the conveyance of community realty. If it is established that the nonsigning spouse informally consented to the transaction effected by the other spouse, the joint management requirement is satisfied, and the nonsigning spouse cannot rescind. ${ }^{219}$ It is curious that the Washington courts ignore the plain language of the statute regarding joint management of community realty.

Even if both spouses have not initially approved the transaction according to the applicable statutory requirement, the transaction can be ratified by the nonsigning spouse. ${ }^{220}$ Ratification is "the affirmance by a person of a prior act

212. See infra notes 289-94 and accompanying text.

213. NEv. Rev. STAT. \& 123.230; WASH. REv. CODE ANN. \$ 26.16.030.

214. CAL. Civ. CODE ANN. \& 5127; IDAHo CODE $\$ 32-912$ (Supp. 1992); Nev. Rev. STAT. ANN. $\$$ 123.230; WASH. ReV. CODE ANN. $\$ 26.16 .030$.

215. ARIZ. REv. Stat. ANN. \$ 25-214 ("joinder" required); N.M. STAT. ANN. 40-3-13. Texas also requires "joinder" for transactions involving a homestead. TEX. FAM. CODE ANN. $\$ 5.81$ (West Supp. 1992).

216. LA. CIV. CODE ANN. art. 2347 (West 1985).

217. The New Mexico Supreme Court has held that the statutory requirement that the spouses "join" means that they both should sign the documents. Hannah v. Tennant, 589 P.2d 1035 (N.M. 1979).

218. Marriage of Stephenson, 209 Cal. Rptr. 383, 393-94 (Cal. Ct. App. 1984).

219. See Reid v. Cramer, 603 P.2d 851, 854 (Wash. Ct. App. 1979); Daily v. Warren, 558 P.2d 1374 (Wash. Ct. App. 1977). In Nichols Hills Bank v. McCool, 701 P.2d 1114, 1117 n.2 (Wash. 1985), the court stated that the joint management requirement for real estate transactions is "essentially" the same as that for gifts. See generally Harry M. Cross, The Community Property Law in Washington, 49 WASH. L. REV. 729, 785-87 (1974).

220. See Kellejian v. Kesicki, 612 P.2d 63 (Ariz. Ct. App. 1980); Kee v. Francis Camel Constr., 532 So. 2d 378 (La. Ct. App. 1988). 
which did not bind him but which was done . . on his account."221 If one spouse accepts the benefits of a unilateral transaction by the other after learning of the transaction, it is ratified. ${ }^{222}$ It is a question of fact whether ratification should be inferred when a spouse fails to act after receiving notice of the transaction. ${ }^{223}$ In those states where both spouses must sign the document conveying or encumbering property, it is unclear whether written evidence of ratification is required. ${ }^{224}$

The exception to joint management that has caused the most confusion has been estoppel. Equitable estoppel, sometimes called estoppel in pais, requires a false representation made by the party to be estopped, made with the intention that the other act on it, and the third party must detrimentally rely on it. ${ }^{225}$ In most disputes involving joint management, courts have applied estoppel in this way. ${ }^{226}$ A spouse will be estopped to rescind a transaction only where the nonsigning spouse has done or said something that caused the third party reasonably to change position in reliance. ${ }^{227}$ In contrast, other courts have held that a spouse is estopped to rescind a transaction unilaterally conducted by the other spouse merely upon a showing that the objecting spouse knew of the transaction and did not object. ${ }^{228}$ The basis of these holdings is unclear. These courts may have concluded that inaction in this context should constitute ratification. The Restatement (Second) of Agency states that inaction should constitute ratification only when, according to ordinary experience, the person would be expected to speak if that person did not consent. ${ }^{229}$ It is questionable

221. RESTATEMENT (SECOND) OF AGENCY \& 82 (1957). The action by the spouse must pertain to the prior unilateral act by the other spouse. So, in Meritor Sav. Bank v. Camelback Canyon Investors, 792 F. Supp. 697, 697 (D. Ariz. 1992), the court held that a spouse did not ratify a prior loan and encumbrance of community realty when she signed a financial statement in connection with a proposed modification of the original loan.

222. See Kellejian, 612 P.2d at 64-65; Otero v. Wheeler, 701 P.2d 369, $372-73$ (N.M. 1985). See also Lane v. Lane, 375 So. $2 \mathrm{~d} 660$ (La. Ct. App. 1978). Arizona courts have permitted the nonsigning spouse to challenge a transaction regardless of whether the community has received a benefit therefrom. See First Interstate Bank v. Tatum and Bell, 821 P.2d 1384 (Ariz. Ct. App. 1991); Consolidated Roofing \& Supply v. Grimm, 682 P.2d 457 (Ariz. Ct. App. 1984).

223. See Nichols Hills Bank, 701 P.2d at 1117-18; Restatement (SECOND) of AGENCY $\$ 94$.

224. Some Washington courts have concluded that ratification may occur without a writing. Daily v. Warren, 558 P.2d 1374, 1377 (Wash. Ct. App. 1977); Everest v. Levenson, 551 P.2d 159, 160 (Wash. Ct. App. 1976). It is unclear why the Washington statute should be so construed.

225. See Foster v. Killearn Acres Homeowners Assoc. v. Keever, 595 So.2d 1019 (Fla. Ct. App. 1992); Watson v. Nortex Wholesale Nursery, 830 S.W.2d 747 (Tex. Ct. App.-Tyler 1992, writ requested); Monroe v. Monroe, 594 A.2d 577 (Md. Ct. App. 1991); Brown v. Corn Exch. Nat'l Bank \& Trust Co., 42 A.2d 474 (N.J. Ch. 1945); Mitchell v. McIntee, 514 P.2d 1357 (Or. Ct. App. 1973); Peplinski v. Campbell, 226 P.2d 211 (Wash. 1951).

226. Some states have applied quasi-estoppel to bar a spouse who has accepted the benefits of a transaction from challenging a transaction unilaterally conducted by the other spouse. See, e.g., Matter of Davidson, 947 F.2d 1294 (5th Cir. 1991). This article has discussed this as a type of ratification. See supra notes 220-24 and accompanying text.

227. See Maricopa Laundry Co. v. Levandoski, 9 P.2d 1014, 1015 (Ariz. 1932); Klaas v. Haueter, 745 P.2d 870, 875 (Wash. Ct. App. 1987); Nichols Hills Bank, 701 P.2d at 1118; Colorado Nat'l Bank of Denver v. Merlino, 668 P.2d 1304, 1308 (Wash. Ct. App. 1983).

228. See Brown v. Burnside, 487 P.2d 957, 960 (Idaho 1971); Reid, 603 P.2d at 854.

229. RESTATEMENT (SECOND) OF AGENCY $\$ 94 \mathrm{cmt}$. a. 
whether a spouse should be required immediately to object to a transaction after notice or be barred from objecting. Most spouses would want to discuss the transaction with their spouse and think about it before acting. This extension of estoppel is unwise; estoppel should be limited to those situations where the objecting spouse's actions induced detrimental reliance by a third party.

\section{b. One spouse purporting to sell fifty percent of joint management community} property. The joint management statutes clearly state that all of the community interest can be conveyed only when both spouses consent. It is less clear whether one spouse can convey her one-half interest in the community without the consent of the other. In other words, the issue is whether a joint management community property interest will be perceived as a tenancy in common, or whether it better resembles a tenancy by the entireties. The latter cannot be severed by the act of one spouse, ${ }^{230}$ while the former can be so severed. ${ }^{231}$

Louisiana law expressly bars a spouse from conveying his one-half interest in community property. ${ }^{232}$ Before 1990 , California courts reached conflicting conclusions regarding this issue. Some accepted that a spouse can sell a one-half interest in community property despite the objection of the other spouse during marriage, thereby effectively partitioning the property into equal shares; ${ }^{233}$ others did not accept that one spouse could do this. ${ }^{234}$ The California Supreme Court recently resolved this conflict, holding that, during an intact marriage, one spouse does not have the power to sell or encumber a one-half interest in community realty over the objection of the other spouse. ${ }^{235} \mathrm{~A}$ similar split has arisen in Texas. One opinion contains dictum that one spouse may convey a one-half interest in joint management community property; ${ }^{236}$ another disagrees. ${ }^{237}$

Allowing one spouse to convey or encumber a fifty percent interest in community property realty could substantially reduce the value of the community estate. In many instances a fifty percent interest in realty is not as marketable or valuable on a pro rata basis as a one-hundred percent fee interest. If spouses

230. See John D. Cribbett \& Corwin W. Johnson, Principles of the Law of Property 10214 (3rd. ed. 1989); Keith D. Ross, Book Note, Sharing Debts: Creditors and Debtors Under the Uniform Marital Property Act, 69 MINN. L. Rev. 111, 117 (1984).

231. See CRIBBETT \& JOHNSON, supra note 230, at 111-12; Ross, supra note 230, at 117.

232. LA. CIv. COdE ANN. art. 2337 (West 1985). See Jeffer Investments, Inc. v. Bernard, 511 So. 2d 1169, 1171 (La. Ct. App. 1987).

233. See Heuer v. Heuer, 201 P.2d 385, 387 (Cal. 1949); Head v. Crawford, 202 Cal. Rptr. 534, 538

(Cal. Ct. App. 1984); Mitchell v. American Reserve Ins. Co., 167 Cal. Rptr. 760,761 (Cal. Ct. App. 1980).

234. See Droeger v. Friedman, Sloan \& Ross, 267 Cal. Rptr. 178, 180-81 (Cal. Ct. App. 1990); Harper v. Raya, 201 Cal. Rptr. 563, 565-66 (Cal. Ct. App. 1984); Andrade Dev. Co. v. Martin, 187 Cal. Rptr. 863, 866 (Cal. Ct. App. 1982).

235. Droeger v. Friedman, Sloan \& Ross, 283 Cal. Rptr. 584, 590-92 (Cal. 1991).

236. Vallone v. Miller, 663 S.W.2d 97, 98-99 (Tex. Ct. App.-Houston [14th Dist.] 1983, writ ref'd n.r.e.). See also Williams v. Portland State Bank, 514 S.W.2d 124, 126-27 (Tex. Civ. Ct. App.-Beaumont 1974, writ dism'd) (holding that one spouse can encumber $50 \%$ of joint management community property).

237. Dalton v. Don J. Jackson, Inc. 691 S.W.2d 765, 768 (Tex. Ct. App.-Austin 1985, no writ). 
disagree regarding the management of community realty, a preferable remedy would be one that left the community interest intact rather than severed.

c. Gifts. In all states, at least some gifts of community property are joint management transactions. ${ }^{238}$ In some, both spouses must consent to all gifts, regardless of size; ${ }^{239}$ in others, only a gift of more than a "reasonable" amount of the community requires mutual consent. ${ }^{240}$

(1) What Are Gifts? In many states it is not clear what types of transactions are covered by the management rules regarding gifts. In all states, a transfer by one spouse, who had donative intent and received no consideration from the recipient, certainly is a gift. ${ }^{241}$ In this context, the crucial facts involve the transferor's donative intent.

For example, in Estate of Bray, ${ }^{242}$ a husband employed a son from a prior marriage in the family business, which apparently was operated as a proprietorship. The business paid the son a salary and an annual bonus. In addition, the husband deposited community funds from the business into a joint tenancy account opened in both his and his son's names. When the father died, the widow challenged the unilateral deposits into the account. The son argued that these deposits were additional compensation for his services and that the wife's consent, therefore, was not needed. The probate court agreed with the son and did not require him to refund any of the amounts deposited. The appellate court reversed; it determined that there was insufficient evidence that the transferor received valuable consideration. The court emphasized that the son already received a salary and a bonus, and the father never was obligated to deposit any amount in the account. ${ }^{243}$

Gifts can occur via transactions other than a direct transfer of property. In Nichols Hills Bank v. McCool, ${ }^{244}$ a spouse signed a guarantee of a loan to his son, who defaulted. The court held that because the guarantee was signed solely

238. Interspousal gifts are never joint management transactions, however.

239. CAL. CIV. CODE ANN. \& 5125 (West Supp. 1992); Anderson v. Idaho Mut. Benefit Ass'n, 292 P.2d 760, 764 (Idaho 1956); Nev. Rev. STAT. ANN. $\$ 123.230$ (Michie 1986); WASH. REV. Code ANN. $\$ 26.16 .030$ (West 1986).

240. Wis. STAT. ANN. $\$ \S 766.51,766.53$ (West Supp. 1992) (one spouse may make a gift of $\$ 1000$ per year to a third party; additional gifts are appropriate if "reasonable" considering the economic position of the spouses); LA. CIV. CODE ANN. art. 2349 (West 1985) (a gift of a value "commensurate with the economic position of the spouses" does not require joint consent); Gaethje v. Gaethje, 442 P.2d 870, 87273 (Ariz. Ct. App. 1968); Jeffer Investments v. Bernard, 511 So.2d 1169, 1171 (La. Ct. App. 1987); Horlock v. Horlock, 533 S.W.2d 52, 55 (Tex. Civ. Ct. App.-Houston [14th Dist.] 1975, writ dism'd w.0.j.) (a spouse may make a gift of a "reasonable amount" of community property). Cf. Roselli v. Rio Communities Service Station, Inc., 787 P.2d 428, 433 (N.M. 1990) (indicating that New Mexico would also follow the reasonable gift rule). See generally REPPY \& SAMUEL, supra note 1, \$§ 15-24 to 15-26.

241. See REPPY \& SAMUEL, supra note $1, \S \S 15-24$ to $15-25$. If the transferor receives some consideration but has donative intent, the transfer could be a partial gift. Id. See infra notes 250-55 and accompanying text.

242. 40 Cal. Rptr. 750 (Cal. Dist Ct. App. 1964).

243. In Mundell v. Stellmon, 825 P.2d 510 (Idaho Ct. App. 1992), a case similar to Bray, the court of appeals affirmed the trial court's holding that the transfer of community property from the father to the son was additional consideration for the son's services, not a gift.

244. 701 P.2d 1114 (Wash. 1985). 
out of parental affection, the guarantee constituted a gift of community credit. Although the husband's separate estate was liable, the community was not bound because both spouses did not consent to the guarantee.

Most transfers that could be governed by the "gift" joint management rules are transfers with donative intent for which the transferor receives no consideration. ${ }^{245}$ Other transfers are sometimes made, however, that arguably should also fall within this class. For example, a spouse sometimes transfers funds to a third party to satisfy an unenforceable promise, or for some other reason feels morally obliged to pay. In this instance, although the community receives no consideration, there is no donative intent.

In Singh v. Singh, ${ }^{246}$ the husband owed his brother wages, but a substantial portion of this claim was barred by the applicable statute of limitations. The brother sued for the wages, and the husband permitted the brother to obtain a default judgment and then, apparently, paid him. When the wife later challenged this payment, the court held that the payment of the judgment was a moral obligation, not a gift requiring the wife's consent. ${ }^{247}$

In Novo v. Hotel del Rio, ${ }^{248}$ the husband used community funds to pay a gambling debt. The statute then in force in California required joint management for gifts and a "disposal of community personal property without a valuable consideration." 249 The wife argued that, because the debt was unenforceable in California, the payment was without consideration and, therefore, required her consent. The court agreed and let her recover the payment.

Most states' statutes do not clearly state that a transfer without donative intent of community property to satisfy a moral obligation should fall within the joint consent rules for gifts. Extending the rules applicable to gifts to such transfers would be a sensible interpretation of the policies underlying the gift regulations. Either spouse is permitted to conduct most commercial transactions involving community personalty because a spouse, presumably, is attempting to advance the economic welfare of the community in a commercial transaction. The community receives something of value in a commercial transaction. However, both gifts and transfers for no consideration deplete the community; no financial benefit accrues to the community and community funds are expended. In this sense, a transfer to satisfy a moral obligation is no different from a gift. Compared to commercial transactions, a greater need exists to ensure that spouses are in accord that community property should be used for these purposes.

245. See Marriage of Stephenson, 209 Cal. Rptr. 383 (Cal. Ct. App. 1984); Mazique v. Mazique, 742 S.W.2d 805 (Tex. Ct. App.-Houston [1st Dist.] 1987, no writ); Horlock, 533 S.W.2d 52.

246. 496 So.2d 506 (La. Ct. App. 1986).

247. Professor Reppy has commented to the author that a claim barred by the statute of limitations still can constitute technical consideration, so Singh does not really involve a payment only to satisfy a moral obligation, although the court apparently thought it was. The statute of limitations bars offensive use of the claim as a plaintiff but does not bar its defensive use as a defendant to reduce sums owed.

248. 295 P.2d 576 (Cal. Dist. Ct. App. 1956).

249. CAL. CIV. CODE \& 5125 (rev. 1986). 
A third type of transaction that could fall within the gift rules involves a sale of community property for less than fair market value. If it could be established that the transferring spouse had donative intent, the transfer would be a partial gift. $^{250}$ The California legislature apparently was persuaded that it would be difficult to establish donative intent in this circumstance; the applicable statute was recently revised so that a sale of community personal property for "less than fair and reasonable value" requires joint action, and donative intent does not have to be established. ${ }^{251}$

This new California policy of extending joint management rules creates a burden on a manager of the community estate, a duty to investigate the fair value of an asset before selling it. For example, if a spouse sells an item in good faith, and by the time of divorce it is learned that the item was made by a noted artist and thus was much more valuable than the sales price, does the selling spouse have to reimburse the community for this mistake? ${ }^{252}$ Take a simpler example: A spouse sells a car for $\$ 5000$ whose fair market value is $\$ 7000$. Spouses traditionally have not been liable for negligent management of the community. ${ }^{253}$ The new California statute seems a backhanded way of establishing such liability, since most states permit a nonconsenting spouse to sue either the donor or the donee for the value of an unauthorized gift. ${ }^{254}$ Indeed, the statute views the manager as a guarantor; even a spouse who sells an item of community property for less than fair market value, after non-negligently expending extensive efforts to determine the value, will apparently be liable. The problems that could be generated by this statute are exacerbated by the California rule that permits one spouse to challenge, at dissolution of marriage, any unilateral gift by the other spouse during the marriage, regardless of when the objecting spouse learned of the gift. ${ }^{255}$ This state of the law is a mistake, since it will increase the latent hostility of divorcing parties and will increase the cost of divorce.

(2) Permitting a Unilateral Gift of a Reasonable Amount of Community Property. Some states permit a unilateral gift of a "reasonable" amount of community property; ${ }^{256}$ therefore, disputes regarding reasonableness are not

250. See REPPY \& SAMUEL, supra note $1, \S 15-26$.

251. CAL. CIV. CODE ANN. $\$ 5125$. The law does not specify whether the objecting spouse would have to tender the consideration given by the buyer. In light of Mark v. Title Guar. \& Trust Co., 9 P.2d 839,844 (Cal. Ct. App. 1932), this will be required, however. See supra notes 209-10 and accompanying text.

252. This is not a law professor's far-fetched hypothetical. Julian Schnabel, now an established painter, whose works are quite valuable, was a young artist in Houston. He gave a number of friends and creditors art as presents and payments of bills. Mr. Schnabel then moved to New York and has had great success. I am sure a number of Houston residents who possessed works by Mr. Schnabel disposed of these objects for much less than their value, unaware of Mr. Schnabel's success.

253. See infra notes 335-60 and accompanying text.

254. See infra notes $296-99$. The California statute apparently does provide a remedy against either the donee or the donor, whereas if the statute were only phrased in terms of the manager's duty, the spouse could recover only from the donor.

255. See infra note 317 and accompanying text.

256. See supra note 240. 
uncommon in those states. Most courts have concluded that the reasonableness of a gift depends on the identity of the donee, the economic position of the spouses, and whether the gifts substantially depleted the marital estate or negatively affected the ability of the spouses to be economically self-sufficient. $^{257}$

Those states that, by judicially created rule, require no consent for one spouse's gifts of a reasonable amount of community property do not discuss why this concept is accepted. It does seem reasonable to permit de minimis unilateral gifts. It would be quite burdensome to require joint action on every gift, and no real benefit would be achieved. Could one spouse seriously object if the other makes a small donation to the American Cancer Society or gives some money to a homeless person? So a sensible policy justification for the reasonable gift rule is that judicial time should be allocated to economic disputes only if the dispute involves a "significant" amount of money.

It is interesting, however, that the concept of a "reasonable gift" extends beyond any notion of de minimis amounts. For example, Wisconsin allows one spouse to give (without consent) $\$ 1000$ annually to a third person, and such spouse apparently may make gifts in this amount to more than one person in any one year. ${ }^{258}$ Also, a spouse may make a unilateral gift of more than $\$ 1000$ if it is "reasonable." 259 The statute gives no guidance regarding what is a reasonable gift. Case law in Texas regarding "reasonable gifts" has permitted sizeable gifts of community funds during marriage. ${ }^{260}$ It is possible that the drafters of the Wisconsin provision felt that $\$ 1000$ reflected the minimum amount that should be in dispute before warranting judicial resolution. If this is true, however, why permit larger unilateral gifts if "reasonable"?

The "reasonable gift" rule acts, in most instances, to bar spouses from disputing small, unilateral gifts. ${ }^{261}$ This bar simplifies divorce and succession litigation, particularly if all unilateral gifts made at any time during the marriage could otherwise be challenged. In contrast, the California rules permit a spouse to challenge all unilateral gifts made by the other during marriage. ${ }^{262}$ The rule is bad policy for both divorce and succession proceedings; it certainly seems desirable to limit in some manner the unilateral gifts made during marriage that could be challenged by a spouse in dissolution litigation. This could be

257. See, e.g., Redfearn v. Ford, 579 S.W.2d 295, 297 (Tex. Civ. Ct. App.-Dallas 1979, writ ref'd n.r.e.); Givens v. Girard Life Insurance Co., 480 S.W.2d 421, 426 (Tex. Civ. Ct. App.-Dallas 1972, writ refd n.r.e.).

258. Wis. STAT. ANN. $\$ 766.53$ (West Supp. 1992).

259. Id.

260. See, e.g., Tabassi v. NBC Bank, 737 S.W.2d 612 (Tex. Ct. App.-Austin 1987, writ ref'd n.r.e.) (approving the husband's gifts of a substantial amount of community funds to his children from a prior marriage); Horlock v. Horlock, 533 S.W.2d 52, 55-56 (Tex. Civ. Ct. App.-Houston [14th Dist.] 1975, writ dism'd w.o.j.) (same).

261. If a spouse makes a number of small gifts, it is conceivable that, in the aggregate, such gifts could be more than a reasonable amount, even though each gift individually would not exceed a reasonableness limit.

262. See supra text accompanying note 255 . 
accomplished via a statute of limitations cutoff of claims, a standard that permitted challenges only of gifts of a significant amount, or both.

As mentioned above, ${ }^{263}$ most states generally apply joint management only to transactions involving a significant amount of community property. Viewed from this perspective, it seems unnecessary to require all gifts of community property, regardless of amount, to be joint management transactions. Still, from the point of view of the community, a gift is different from a commercial transaction. Gifts deplete the community estate, whereas commercial transactions do not (or are not intended to). A spouse might be much more concerned about being consulted regarding gifts, particularly when they exceed de minimis amounts. Also, spouses are likely to have congruent interests in most nongift management disputes; both want to maximize the value of the community. In the gift context, however, disputes are much more likely. For example, one spouse might want to make gifts to children from a prior marriage, and the current spouse could well object. ${ }^{264}$

Reported disputes regarding unilateral gifts frequently pertain to gifts by one spouse to a paramour, ${ }^{265}$ a parent or other relative, ${ }^{266}$ or a child from a prior marriage. ${ }^{267}$ One might be sympathetic toward a parent's desire to support children from a prior marriage or to provide for some other family member in need, but why should one spouse have the power to transfer more than a de minimis amount from the community estate to a family member without the consent of the other spouse? If both spouses truly are equal owners of the community fund, a transfer of a "significant" amount of community assets for no consideration should be a joint decision. Why should one parent's offspring be favored over the other's? Alternatively, the other spouse might want to retain the community funds for the spouses' use.

The problem of gifts to family members is further compounded if the donor also possesses a separate estate. In this situation, it is even more difficult to justify one spouse's possession of the power to divert a substantial amount from the community estate without the approval of the other spouse. ${ }^{268}$ This raises

263. See supra notes $47-48$ and accompanying text.

264. In Horlock, 533 S.W.2d at 54-55, the donor spouse admitted he knew that his spouse would have strongly objected had she known of the gifts. He even forged the wife's signature to a gift tax return so she would not learn of the gift.

265. See Spruill v. Spruill, 624 S.W.2d 694 (Tex. Civ. Ct. App.-El Paso 1981, writ dism'd w.o.j.); Roberson v. Roberson, 420 S.W.2d 495 (Tex. Civ. Ct. App.-Houston [14th Dist.] 1967, writ ref'd n.r.e.).

266. See Jackson v. Smith, 703 S.W.2d 791 (Tex. Ct. App.-Dallas 1985, no writ) (sister); Murphy v. Metropolitan Life Ins. Co., 498 S.W.2d 278 (Tex. Civ. Ct. App.-Houston [14th Dist.] 1973, writ ref'd n.r.e.) (mother); Hartman v. Crain, 398 S.W.2d 387 (Tex. Civ. Ct. App.-Houston [1st Dist.] 1966, no writ) (sister).

267. See, e.g., Estate of Korzekwa v. Prudential Ins. Co., 669 S.W.2d 775 (Tex. Ct. App.-San Antonio 1984, no writ). Some disputes pertain to gifts to children of the current marriage. See Redfearn v. Ford, 579 S.W.2d 295 (Tex. Civ. Ct. App.-Dallas 1979, writ refd n.r.e.); Marriage of McCurdy, 489 S.W.2d 712 (Tex. Civ. Ct. App.-Amarillo 1973, writ dism'd w.o.j.).

268. Cf. Horlock, 533 S.W.2d at 52 (divorce court determined that the husband's gifts of community property to his daughters from a prior marriage were reasonable-and therefore should not be recoverable by the wife-even though the husband had a substantial separate estate). 
the related issue of when, if ever, it is reasonable to charge the community with all or a portion of such gifts, where the donor has a substantial separate estate. The appropriateness of charging the community with the gift should depend upon the nature of the gift. If the donation supports general charitable purposes, it may be fair to charge the community estate for a "reasonable" gift. This conclusion would be based upon the notion that some annual charitable "tithing" from income is a moral obligation, like the income tax. Even in this context, some might argue that both spouses should approve the identity of the charitable donee. However, gifts to children from prior marriages or gifts to parents are not justifiable on these grounds and are more appropriately charged to the separate estate first. Due to the corrosive effect upon a marriage of gifts to lovers during an intact marriage, such unilateral expenditures are never appropriate, regardless of the size of the separate estate. ${ }^{269}$

When determining the reasonableness of a gift of community funds, courts have not utilized the analysis suggested in the preceding paragraph. For example, in Horlock $v$. Horlock, ${ }^{270}$ during marriage the husband gave $\$ 131,000$ of community property to his children from a prior marriage. The court found these gifts to be reasonable in light of the spouses' community wealth (which was approximately $\$ 3$ million at divorce), even though the husband possessed a separate estate of about $\$ 1$ million.

In Tabassi v. NBC Bank, ${ }^{271}$ during marriage the husband gave $\$ 495,000$ of community property to his children from a prior marriage. Somewhat incredibly, the court determined that these gifts were reasonable. This case is quite unusual. Even at the time of the gift, the amount apparently represented approximately thirty percent of the community estate. ${ }^{272}$ The court appeared to be swayed by the parties' premarital agreement, which specifically mentioned the husband's intention to transfer funds during marriage to his children.

Tabassi also presented the interesting question of when the reasonableness of the gift is to be judged. When the husband made these gifts, a great deal of money remained in the community estate. However, when the gift was challenged, after the husband died, the executor discovered that the husband and

269. A different rule might be appropriate after separation in some states. See infra note 285 and accompanying text.

270. 533 S.W.2d 52 (Tex. Civ. Ct. App.-Houston [14th Dist.] 1975, writ dism'd w.o.j.).

271. 737 S.W.2d 612 (Tex. Ct. App.-Austin 1987, writ ref'd n.r.e.).

272. In Horlock, 533 S.W.2d at 56, the court emphasized that the amount given could not have been more than about $13 \%$ of the amount controlled by the donor spouse. Still the question in Horlock is more complicated than the court says. The donor owned $\$ 1$ million of separate funds at the start of the marriage, which was then commingled into the community estate. Although these funds were commingled and could not be traced, the divorce court reimbursed the donor's separate estate for the $\$ 1$ million contributed to the community via commingling. There was no evidence of the value of the community estate at the time the donor made the gifts, other than the court's assumption that the commingled $\$ 1$ million had not been dissipated. The court effectively treated the commingled $\$ 1$ million as if it were traceable separate property throughout the marriage, so there was no evidence that any community property existed at the time of the gifts. This would have been another reason to consider the gifts unreasonable in Horlock, in addition to the size of the donor's separate estate (that is, a $\$ 1$ million claim against the community). 
wife owed $\$ 1$ million in back taxes, and the wife therefore owed $\$ 500,000$. The court appeared to judge the reasonableness of the gift at the time the gift was made, not at the time of the litigation. Such an approach would create more certainty regarding the validity of unilateral gifts in states that permit unilateral gifts of a reasonable amount of community property. Also, if the donor is liable to the community for an unlawful unilateral gift of an "unreasonable" amount of community property, it would be fair to determine this liability based upon the situation as it appeared at the time the donor made the gift, rather than after circumstances had changed. The Louisiana statute supports this analysis, permitting unilateral gifts of a value "commensurate with the economic position of the spouses at the time of the donation."273 The Wisconsin statute also ties the determination regarding reasonableness to the circumstances that existed at the time of the gift. ${ }^{274}$

(3) Gifts from a Community Property Business. A spouse managing a community property business might want the business to make a gift to a third party. In addition, the manager might want to transfer money for no lawful consideration, thereby also potentially triggering joint management requirements. ${ }^{275}$ For example, if an employer pays a bonus, sends flowers to a sick employee, or even leaves a tip at a restaurant, the employer is transferring funds for no lawful consideration. Proprietorship businesses require special rules for "gifts," particularly in those states where all gifts of community property normally must be jointly made.

In California, a spouse who is "operating or managing" a business "may act alone in all transactions [involving the business]."276 This rule seems to empower the managing spouse to make a unilateral gift, assuming that a gift from the business is a "transaction," even though all gifts in California normally must be made jointly. A very valuable gift might still constitute an act in bad faith and could be rescinded by the nonmanager.

The analogous Washington statute says that, where only one spouse participates in the management, that spouse unilaterally may "convey" its assets. $^{277}$ One meaning of "convey" is "to transfer; [to] pass . . title;" 278 so this statute also seems to permit the manager to make unilateral gifts despite the general Washington rule that all gifts of community property must be jointly made. $^{279}$

A Louisiana statute gives the "sole manager" of an enterprise the exclusive right "to alienate, encumber, or lease its movables." 280 Black's Law Dictionary

273. LA. CIv. CODE ANN. art. 2349 (West 1985).

274. Wis. STAT. ANN. \& 766.53 (West Supp. 1992).

275. For example, a manager might provide free food and drink for employees at a holiday party, pay a bonus, or give a holiday present to a client.

276. CAL. CIv. CODE ANN. \& 5125(d) (West Supp. 1992).

277. WASH. REV. CODE ANN. \$ 26.16.030(6) (West 1986).

278. AMERICAN COLLEGE DICTIONARY 265 (1958).

279. WASH. REV. CODE ANN. \& 26.16.030(2).

280. LA. Civ. CODE ANN. art. 2350 (West 1985). 
defines "alienate" to mean "convey," or "to transfer . . . title." 281 Therefore, the Louisiana proprietorship management statute apparently also includes the right to make a gift. Louisiana accepts the rule that a spouse may make a unilateral gift of a reasonable amount of community property, ${ }^{282}$ so the special power is not required to the same extent.

The Washington and California statutes present the issue of whether the general bar on unilateral gifts of any amount of community property extends to the manager of a community property proprietorship. One rule of construction, when there is a conflict between statutory directives, is to apply the specific, rather than the more general provisions. In this situation, it is unclear which would be considered the more specific. If the restriction on unilateral gifts is considered more specific, a manager of a community property proprietorship would be in the unfortunate position that no unilateral gift would be effective without the consent of the nonmanager. The burdens imposed by requiring joint action for all gifts of community property, regardless of amount, would be compounded if this rule were extended to proprietorship businesses. Surely a manager of such a business should be able to make a gift of a reasonable amount of community property without the approval of the other spouse. This rule could be established by deciding that the rules regarding proprietorship management are more specific, and by creating a judicial limitation that a manager could make a gift without the consent of the other spouse only when the gift is of a reasonable amount of community funds and in the ordinary course of business.

Managers also sometimes choose to make expenditures for which they receive no lawful consideration, but whose purpose is to advance the business. For example, a manager might provide free food and drink for employees at a holiday party, pay a bonus, or give a holiday present to a prospective client. No consideration is received, but all seem quite appropriate. Therefore, it would not be wise to extend joint management rules to transactions where a manager of a proprietorship makes an expenditure for no consideration in the ordinary course of business.

(4) Expenditures on Paramours. A consensus has evolved that any unilateral expenditure on a paramour is inappropriate, regardless of the amount, and regardless of whether the jurisdiction generally accepts the rule that a spouse may make a unilateral gift of a reasonable amount of community property. ${ }^{283}$ Due to the corrosive effect of such expenditures upon intact marriages, this rule seems wise when applied to expenditures before separation. ${ }^{284}$

281. BLACK'S LAW DiCTIONARY 72 (6th ed. 1990).

282. LA. CIV. CODE ANN. art. 2349.

283. See Spruill v. Spruill, 624 S.W.2d 695 (Tex. Civ. Ct. App.-El Paso 1981, no writ); Mazique v. Mazique, 742 S.W.2d 805 (Tex. Ct. App.-Houston [1st Dist.] 1987, no writ). See generally W. Reed Quilliam, Jr., Gratuitous Transfers of Community Property to Third Persons, 2 TEX. TECH L. REV. 23, 43-44 (1970); Stanley M. Johanson, Revocable Trusts and Community Property: The Substantive Problems, 47 TEX. L. REV. 537, 568 (1969).

284. Many cases involving expenditures on a paramour involve expenditures before separation. See Fanning v. Fanning, 828 S.W.2d 135 (Tex. Ct. App.-Waco 1992, writ denied); Morrison v. Morrison, 
It is also sensible to apply this rule regarding expenditures after separation in those states where couples stop earning community property after separation. ${ }^{285}$ In these states, each spouse will begin accumulating separate property after separation (if each is working), and should use this money to pay for postseparation living expenses, including socializing. So, although post-separation dating is not offensive to most people (when compared to the offensiveness of an affair during an intact marriage), it is still an act of bad faith to use community funds for post-separation living expenses as long as separate funds are available.

The rule makes less sense when applied in those states where spouses continue to earn community property until the divorce process ends. ${ }^{286}$ In such a situation, it is quite possible that a spouse will not have any separate property until the divorce process ends. ${ }^{287}$ In this situation, if the spouse has no separate property, the spouse has no choice but to use community funds for postseparation living expenses, including the cost of "dating." It, therefore, would be appropriate, in those states where spouses continue earning community property until the divorce decree is entered, to permit a spouse to spend a reasonable amount of community property on "dates" after separation. ${ }^{288}$ Of course, if the spouse spent more than a reasonable amount, such spending should be considered to be in bad faith.

(5) Satisfying the Requirement of Joint Action. Gifts are subject to joint management. In some states, all gifts must be made jointly; in others, only a gift of more than a reasonable amount of community property requires joint action. Different standards have been established for what satisfies the joint action requirement.

California curiously permits a spouse to make a gift to a third party only if the other spouse gives written consent. ${ }^{289}$ This policy renders voidable almost all gifts during marriage, regardless of whether the nondonor had notice and

713 S.W.2d 377 (Tex. Ct. App.-Dallas 1986, writ dism'd w.o.j.); Mazique, 742 S.W.2d at 805 . Indeed, given contemporary notions of morality, it is a strained usage to refer to a dating expenditure after separation as an expenditure on a paramour.

285. CAL. Civ. Code ANN. $\$ 5118$ (West 1983); WAsh. Rev. Code ANN. $\$ 26.16 .140$ (West 1986).

286. This is true (absent an express or implied transmutation agreement between the spouses) in all seven states other than California and Washington. See REPPY \& SAMUEL, supra note 1, \$\$ 6-16 to 6-23.

287. This could also be true in California and Washington, if a spouse is not working outside the home and not receiving spousal support.

288. Courts do not now follow the "Oldham rule"; expenditures on a new partner after separation have been treated as no different from expenditures before separation on a mister/mistress. See Spruill, 624 S.W.2d at 694; Givens v. Girard Life Ins. Co., 480 S.W.2d 421 (Tex. Civ. Ct. App.-Dallas 1972, writ refd n.r.e.); Roberson v. Roberson, 420 S.W.2d 495 (Tex. Civ. Ct. App.-Houston [14th Dist.] 1967, writ ref'd n.r.e.). However, in many of these cases the spouse spent a large amount on the new partner. See Spruill, 624 S.W.2d at $697-98(\$ 30,000)$; Givens, 480 S.W.2d at 423 ( $\$ 4,000$ life insurance policy, the sole asset of any value owned by the husband); Roberson, 420 S.W.2d at $501(\$ 10,000)$. In Spruill and Roberson, the donor spouse lived with the new partner and apparently provided financial support. Such expenditures are excessive and would not be permitted under the reasonable social expenses approach that I have proposed.

289. See CAL. Civ. CODE ANN. \& 5125 (West Supp. 1992). This does not apply if the gift was "mutually" given by both spouses. See id. $\$ 5125(\mathrm{~b})$. 
consented. For example, in Marriage of Stephenson, ${ }^{290}$ the husband and wife established gift bank accounts for their children. The husband deposited funds into some accounts, and the wife made deposits in others. At divorce, the wife challenged the husband's deposits into the accounts. Evidence was admitted that the wife knew of, and participated in, the spouses' program of depositing, as gifts, community funds in the accounts. The court of appeal held that this was insufficient evidence of consent; the statute required written consent, and it had not been obtained.

The California policy of requiring written consent seriously undermines any finality regarding the validity of most gifts during marriage. Most couples do not consent in writing to gifts by the other spouse, but in most instances informally approve them. In light of this convention, most states more sensibly require only "concurrence" 291 or "implied consent" $" 292$ to satisfy the joint action requirement.

Few cases to date consider what must be shown to establish implied consent or concurrence. If both spouses make a gift of tangible property or sign the check, the tacit approval obviously suffices. Unfortunately, many gifts are not made in this manner. During a reasonably amicable marriage, gifts are made informally. One spouse might tell the other that she gave her mother a present, or sent a check to her son at college. Similarly, one spouse might be present when the other makes a gift to someone.

To establish that the other spouse concurred or gave implied consent, it would be sensible to require evidence from which one could infer that the nondonor did not object. If the nondonor affirmatively consents to the gift, the consent obviously should suffice. Professor Reppy has suggested ${ }^{293}$ that if a spouse signs a joint tax return, such joint filing might constitute consent to any charitable gifts set forth on the schedule regarding deductible gifts. ${ }^{294}$ If a spouse receives notice of the gift but says nothing, mere notice should not

290. 209 Cal. Rptr. 383 (Cal. Ct. App. 1984).

291. See LA. Civ. Code ANN. art. 2349.

292. See NEV. REV. STAT. ANN. $\$ 123.230$ (Michie 1986) (implied consent); WASH. REV. CODE ANN. $\$ 26.16 .030$ (implied consent). Wisconsin requires spouses to "act together." WIS. STAT. ANN. $\$ 766.53$ (West Supp. 1992). This requirement does not require spouses to act simultaneously; subsequent consent by the nondonor is sufficient. See WIS. STAT. ANN. \& 766.53, Legislative Council Committee Supplemental Notes.

293. Conversation with Professor Reppy, supra note 198.

294. Cf. Jackson v. Smith, 703 S.W.2d 791, 794 (Tex. Ct. App.-Dallas 1985, no writ) (concluding that the wife had not consented to the husband's designation of his sister as beneficiary of his life insurance policy, even though the wife signed the policy application containing the designation). See also Colorado Nat'l Bank of Denver v. Merlino, 668 P.2d 1304, 1308-09 (Wash. Ct. App. 1983) (holding that a spouse was not estopped from later challenging a real estate purchase by the other spouse, where the challenging spouse had signed an income tax return that listed a deduction for interest on this investment). (Remember that in Washington a purchase of community realty is subject to joint management.) The court in Merlino did not explain why the income tax benefit enjoyed by the wife did not constitute a ratification or quasi-estoppel. See supra notes $220-26$ and accompanying text. 
suffice; some affirmative act reflecting consent by the spouse should be necessary. ${ }^{295}$

(6) Remedies for Improper Unilateral Gifts. If one spouse makes a unilateral gift of community property via a transfer that qualifies as a joint management transaction under the law of the forum, the remedies provided in each state differ. In Washington and California, the nondonor may sue the donee and recover the entire property. ${ }^{296}$ In Texas, if the claim is brought at dissolution, the nondonor must first seek recovery from the donor's portion of the community estate. ${ }^{297}$ In these states, even states such as Texas where a spouse has the right to make a gift of a reasonable amount of community property, a gift of an unreasonable amount of community property can be recovered in full by the community. ${ }^{298}$ In contrast, the Wisconsin statute permits the nondonor to sue either the donor or the donee, but only for the amount in excess of a reasonable gift. ${ }^{299}$

If a gift is challenged after dissolution, the nondonor may recover fifty percent of the gift. ${ }^{300}$ W.C. Fields' life provides an example of this rule. W.C.

295. See Nichols Hills Bank v. McCool, 701 P.2d 1114, 1116-1117 (Wash. 1985) (rejecting the argument that silence after notice of a gift establishes consent).

296. See REPPY \& SAMUEL, supra note 1, \& 15-26 (In California, to recover all of the gift, the nondonor must sue before dissolution.). See, e.g., Britton v. Hammell, 52 P.2d 221, 222-23 (Cal. 1935).

297. Estate of Korzekwa v. Prudential Life Ins. Co., 669 S.W.2d 775, 778 (Tex. Ct. App.-San Antonio 1984, no writ); Carnes v. Meador, 533 S.W.2d 365, 371 (Tex. Civ. Ct. App.-Dallas 1975, writ ref'd n.r.e.). At divorce, Texas courts frequently award the complaining spouse a money judgment against the donor spouse. See Mazique v. Mazique, 742 S.W.2d 805 (Tex. Ct. App.-Houston [14th Dist.] 1987); Spruill, 624 S.W.2d at 694; Marriage of McCurdy, 489 S.W.2d 712 (Tex. Civ. Ct. App.-Amarillo 1973, writ dism'd w.o.j.); Roberson, 420 S.W.2d at 495. It is frequently not clear how the amount of the judgment is calculated. In some cases, the amount is the total value of the gifts. See Spruill, 624 S.W.2d at 697-98. Some award the complaining spouse $50 \%$ of the value of the gifts. See Marriage of McCurdy, $489 \mathrm{~S} . \mathrm{W} .2 \mathrm{~d}$ at 717-18. In others, the percentage is not clear. In Texas, the court has substantial discretion regarding how much disputed gifts could be treated, because the community estate does not have to be divided equally at divorce.

298. See Spruill, 624 S.W.2d 694; REPPY \& SAMUEL, supra note 1, \&15-26 to 15-27. It is unclear why an objecting spouse in Texas should be able to recover all of an unreasonable gift. If the spouse has the right to make a unilateral gift of a reasonable amount of community property, it is difficult to understand why the gift should not be valid to that extent, even when a spouse makes a larger gift. This approach, the one adopted by Wisconsin (WIS. STAT. ANN. $\$ 766.70$ (West Supp. 1992)), is easier to justify. For one possible explanation of the Texas rule, see infra note 307 and accompanying text.

Regardless of whether this point is accepted, the objecting spouse should be able to recover only $50 \%$ of the gift when the gift is challenged after the donor dies. In contrast, the full amount of the gift (possibly reduced by the amount of a "reasonable" gift) should be recovered if challenged befure divorce or after divorce, as long as a postdivorce equitable partition would be possible. The postdivorce equitable partition is described, for example, in TEX. FAM. CODE ANN. $\$ 3.90$ (West Supp. 1992).

299. WIS. STAT. ANN. \$ 766.70.

300. See, e.g., id. See also Harris v. Harris, 19 Cal. Rptr. 793, 796 (Cal. 1962); Britton v. Hammell, 52 P.2d 222-23 (Cal. 1935); Bank of California v. Connolly, 111 Cal. Rptr. 468, 486 (Cal. Ct. App. 1973); Jackson v. Smith, 703 S.W.2d 796 (Tex. Ct. App.-Dallas 1985, no writ). See generally REPPY \& SAMUEL, supra note 1, $\$ \$ 15-26$ to 15-27. This rule should apply in all states if the marriage is dissolved by death. The result should be the same if the marriage is dissolved by divorce in those states where the community estate must be divided equally at divorce. This should be the rule after divorce in states where community property not divided at divorce must be divided equally. In a state like Texas, where such property is divided equitably, not equally, a spouse objecting after divorce to a transfer made during marriage should be able to recover all of the value of the gift (possibly reduced by the value of a "reasonable" gift), as long as an equitable postdivorce partition remedy is possible. 
Fields married in 1900; he and his wife separated a few years later, but did not divorce. He lived for more than forty years after the separation and became a famous film star and critic of Philadelphia. California had not yet enacted the rule that a husband's wages after separation were separate property ${ }^{301} \mathrm{Mr}$. Fields' wages after separation were therefore community property. He made gifts after separation to a number of people. After his death, Mrs. Fields challenged these gifts, which she, of course, had never approved. Instead of suing the donees, however, she sued Mr. Fields' estate. The court held that his estate should reimburse her for fifty percent of the value of the gifts. ${ }^{302}$

A related question is whether a spouse's estate can bring suit regarding an improper unilateral gift by the other spouse during marriage. In light of the decedent's vested interest in each item of community property, it seems clear that the answer to this question should be affirmative, as a California court has ruled. ${ }^{303}$ A Louisiana court has reached the opposite conclusion, however..$^{304}$

The amount of reported litigation relating to improper gifts suggests existing remedies are not particularly effective deterrents. For example, the penalty is not particularly severe where one spouse attempts to divert community property and is "caught." Of course, the donor might have to reimburse the community for the value of the property transferred, as well as repay the other spouse for attorneys' fees (if the matter is litigated at divorce). In those states where any unilateral gift is improper, a penalty beyond restoring the value of the property to the community would be overkill, if the value of the gift was not large. If the gift was substantial, however, it might be appropriate to permit a court to grant a remedy in addition to the recovery normally allowed. For example, in Mazique v. Mazique, ${ }^{305}$ Mr. Mazique, during the marriage, went out at night and spent an aggregate of at least $\$ 30,000$ on extra-marital affairs. In a later divorce, the court ordered him to pay $\$ 5,000$ in punitive damages in addition to reimbursing the community for the funds expended. ${ }^{306}$ Without some additional penalty,

301. Cal. Civ. Code ANN. $\$ 5118$ (West 1983).

302. Fields v. Michael, 205 P. 402 (Cal. Ct. App. 1949).

303. Harris, 19 Cal. Rptr. at 794.

304. Alfonso v. Alfonso, 160 So.2d 294 (La. Ct. App. 1964).

305. 742 S.W.2d 805 (Tex. Ct. App.-Houston [1st Dist.] 1987, no writ).

306. See also Fanning v. Fanning, 828 S.W.2d 135 (Tex. Ct. App.-Waco 1992, writ granted), where the trial court awarded damages to a spouse for "constructive fraud" upon proof the obligor had spent community funds on a mistress and donated a large amount of money to charities when the marriage was breaking down. Although the court refers to this award as based upon constructive fraud, the award appeared merely to reimburse the wife for a portion of the community funds so used; no punitive award was granted.

CAL. CIV. CODE $\S 5125.1$ (h) (West Supp. 1992) suggests that if the spouse is guilty of "oppression, fraud or malice," express or implied, the nondonor could sue the donor and recover $100 \%$ of the value of property transferred in breach of the transferor's duty. See also CAL. Civ. CODE ANN. \& 3294 (West 1872). The award presumably would be the separate property of the nondonor. Section $5125.1(\mathrm{~h})$ also states that in these situations the court may, in its discretion, grant an award larger than $100 \%$ of the value of the property transferred.

Marriage of DeVine, 1993 WL 147315 (Tex. App.-Amarillo 1993), involved a spouse who spent community funds during marriage supporting a paramour and his family. The divorce court concluded that this constituted fraud on the community, and awarded punitive damages. The court of appeals 
a few married people will not be significantly deterred from trying to appropriate their spouse's share of the community, ${ }^{307}$ particularly when a marriage is breaking down.

Imposing an additional penalty on a spouse who wastes the community's assets could be grounded in the tort of conversion. ${ }^{308}$ If one spouse sues the other for conversion of the objecting spouse's separate property, no conceptual difficulty is presented; the objecting spouse should be able to recover, as long as the elements of conversion can be established. ${ }^{309}$ A conversion claim against a co-owner, however, presents more difficulty. Because both spouses are coowners, both have the right to possess community property. Conversion would not be established based upon a showing that one spouse used the property. ${ }^{310}$ However, a conversion recovery is still possible if the objecting co-owner can establish ouster by the other co-owner. ${ }^{311}$ One can be guilty of conversion of property, even when taking possession of the property lawfully, if the party in

reversed the punitive damages award. The court concluded that fraud on the community was an inappropriate basis for punitive damages; this behavior by the wife was a factor that the court should consider when dividing the community estate.

In Tyropanis v. Tyropanis, 1992 WL 352802 (Tex. App-Dallas 1992) (unreported opninion), the husband allegedly encouraged the wife to sell property she acquired before marriage and invest the proceeds in Greek realty. The husband conducted these transactions on behalf of the wife, and title was taken in his name alone. This allegedly was done so that under Greek law after the couple's death the property would be inherited by the husband's heirs, not the wife's. The divorce court awarded all of this property to the wife, and also awarded punitive damages of $\$ 200,000$.

In a commercial partnership, some courts have held that, in certain circumstances, punitive damages can be imposed on a partner who violates his fiduciary duty to the other partner. Cheek v. Humphreys, 800 S.W.2d 596 (Tex. Ct. App.-Houston [14th Dist.] 1990, writ denied); Murphy v. Canion, 797 S.W.2d 444 (Tex. Ct. App.-Houston [14th Dist.] 1990, no writ).

307. It might be argued that the rule that all the unreasonable gifts-not just the excessive part thereof-must be returned is intended to discourage a donor from making a gift that might be deemed unreasonable. Most states that permit a spouse to make a "reasonable" gift do permit all of an unreasonable gift to be recovered. Wisconsin does not, however; only the unreasonable amount may be recovered.

308. Conversion has been defined as an intentional exercise of dominion or control over a chattel that so seriously interferes with the right of another to control it that the actor may justly be required to pay the other the full value of the chattel. See William L. Prosser, The Nature of Conversion, 42 CORNell L. Q. 168, 173-74 (1957). See generally William L. Prosser \& W. Page KeEton, Prosser \& KEETON ON THE LAW OF TORTS 815 (5th ed. 1984).

309. See Earthman's Inc. v. Earthman, 526 S.W.2d 192 (Tex. Ct. App.-Houston [1st Dist.] 1975, no writ); Belz v. Belz, 667 S.W.2d 240 (Tex. Ct. App.-Dallas 1984, writ ref'd n.r.e.); Borton v. Borton, 190 S.W.2d 192 (Tex. Ct. App.- 1916, writ ref'd).

310. See, e.g., McVay v. McVay, 318 So.2d 660 (La. Ct. App. 1975). See generally Restatement (SECOND) OF TORTS $2 d \& 272$.

311. See Mazique, 742 S.W.2d at 805 . For a discussion of conversion in other divorce cases, see Grothe v. Grothe, 590 S.W.2d 238 (Tex. Ct. App.-Austin 1979, no writ) (spouses's conversion of community property during marriage justified disproportionate division of the community estate at divorce). Cf. Belz, 667 S.W.2d at 240 (stating that one spouse could not successfully sue the other spouse for conversion of community property). In another case, a spouse was permitted, after divorce, to sue the other spouse for conversion of former community property not divided at divorce. Horlock $v$. Horlock, 614 S.W.2d 478 (Tex. Civ. Ct. App.-Houston [14th Dist.] 1981, writ dism'd). The spouses held the property after divorce as tenants in common, so this case does not involve a claim for the conversion of community property. 
possession later unlawfully encroaches on the rights of a co-owner. ${ }^{312}$ If one spouse unilaterally gives away community property in violation of the forum's joint management rules, this would constitute an ouster. ${ }^{313}$ Punitive damages and mental anguish damages could also be awarded, in the appropriate case..$^{314}$

Some community property states permit a court hearing a dissolution matter to adjudicate a spousal tort claim; other states require a spouse to file a separate action. ${ }^{315}$ In those states that do not permit a court with jurisdiction over the dissolution to adjudicate a tort claim, a spouse would have to file a separate action.

(7) Period Within Which Unauthorized Gifts Must Be Challenged. Many improper gift cases arise in connection with marital dissolution. There are several explanations for this. First, the nondonor spouse might learn of the gift only in connection with a legal proceeding at dissolution. Second, the spouse might have known of the gift, but for whatever reason did not challenge it during the marriage. Also, few spouses challenge a gift during marriage because most states do not permit such an action against the other spouse during marriage. ${ }^{316}$

Unauthorized gift cases present a basic issue: If the spouses cannot resolve the matter amicably, should these disputes be litigated during an intact marriage, or should their resolution be delayed until dissolution, regardless of when the nondonor learns of the gift? Both schemes have drawbacks. Some spouses might be reluctant to litigate during marriage; a scheme that forced them to do so or lose their right to challenge a gift could leave them without an effective remedy. However, the alternative (now accepted by most states) creates too much uncertainty and unfairness. For example, in a California dissolution, a spouse or her representative may challenge any unilateral gift made by the other spouse at any time during marriage. ${ }^{317}$ Such a broad opportunity to challenge gifts could facilitate unfair results. For example, spouses frequently incorporate gifts into an estate plan. When drafting a will, most spouses who do not consult an attorney presumably assume that gifts unilaterally made during marriage are valid. The California system permits the survivor to challenge such gifts, thereby potentially interfering with the testator's wishes. ${ }^{318}$ Similarly, the executor

312. See Mercer v. Wayman, 137 N.E.2d 815 (Ill. 1956). See also Preston v. U.S., 696 F.2d 528 (7th Cir. 1982). See generally David P. Derham, Conversion by Wrongful Disposal as Between Co-owners, 68 L.Q. ReV. 507 (1952). In McVay v. McVay, 318 So.2d 660, 665 (La. Ct. App. 1975), the court affirmed an award of damages for embarrassment and humiliation when one spouse took a community property car from the other spouse.

313. See generally 1 FowLER V. HARPER, Fleming JAMES, JR. \& OSCAR S. GRAY, THE LAW OF TORTS $\$ 2.32$, at 223 (2d ed. 1986).

314. Id. § 2.36, at 238; see Earthman, 526 S.W.2d at 192.

315. See, e.g., Chandler v. Chandler, 18 Fam. L. Rep. (BNA) 1489 (Ill. Ct. App. 1992) (court hearing divorce action cannot hear tort claim).

316. Although some states expressly permit challenge of a gift during marriage (see, e.g., U.M.P.A. § 6; Wis. STAT. ANN. $\$ 766.70(6)$ (West Supp. 1992)), not all states do.

317. CAL. Civ. Code ANN. \& 5125.1(d)(2).

318. This apparently occurred in Estate of Bray, 40 Cal. Rptr. 750 (Cal. Ct. App. 1964). 
could challenge gifts made by the survivor during marriage. ${ }^{319}$ If all unilateral gifts during marriage could be successfully challenged at dissolution, it would significantly affect the estate plan the spouses had agreed upon and greatly complicate probate or divorce proceedings.

It seems reasonable to assume that most spouses informally reach some agreement regarding most unilateral gifts made before the marriage has broken down. $^{320}$ In all states other than California, oral or implied consent by one spouse to a unilateral gift by the other spouse satisfies the joint management requirement. However, if a unilateral gift is challenged by the nondonor at a later date, it could be very difficult for the donor to prove that the other spouse consented. A policy that permits the nondonor to challenge all unilateral gifts during marriage could allow a spouse to challenge successfully many gifts that the spouse had in fact informally approved.

Three different limitations have been proposed to govern challenges to unilateral gifts during marriage. The UMPA provision concludes that finality of transactions is paramount and that spouses should not be invited to fight about gifts made long ago. Under the UMPA provision, a spouse may challenge a gift only within a time frame defined as the earlier of one year from the date the spouse learned of the gift or three years from the date of the gift. ${ }^{321}$ California accepts the other extreme: A spouse is permitted to challenge, at dissolution, any unilateral gift made by the other spouse, regardless of when the gift occurred or when the nondonor became aware of it. ${ }^{322}$ Wisconsin adopted a compromise, one that requires the spouse to challenge a gift within one year after receiving notice of it. ${ }^{323}$

The UMPA provision described above is too extreme. Critics note that the time limitation forces a spouse to challenge a gift during an intact marriage, and bars the nondonor from challenging an improper gift after three years even if the spouse was not aware of it. It would permit a spouse to divert a large amount of the community estate via unilateral gifts, as long as the nondonor did not know about the gift for three years. Before a marriage has broken down, most spouses probably learn of significant unilateral gifts of community funds by the other spouse when the gift occurs. However, reported appellate cases show that spouses sometimes engage in a practice of hiding large gifts from the other spouse throughout the marriage, beginning long before the marriage has broken down. ${ }^{324}$

319. The decedent obviously is no longer around to tell the personal representative whether the gifts were approved by the decedent. It was mentioned above that there is a split of authority regarding whether an estate can challenge unauthorized gifts. See supra notes $303,304$.

320. Of course, this is not always true. See, e.g., Horlock, 533 S.W.2d at 54.

321. See U.M.P.A. $\$ 6$.

322. CAL. CIV. CODE $\$ 5125.1(d)(2)$. California implements a different policy balance regarding a reimbursement claim. A spouse must assert a reimbursement claim within three years of notice of the claim, regardless of whether an action for dissolution is filed by that time. Id. $\$ 5120.210$ (West 1989).

323. WIS. STAT. ANN. \$ 766.70.

324. See Horlock, 533 S.W.2d at 54; Mazique v. Mazique, 742 S.W.2d at 805 (Tex. Ct. App.-Houston [1st Dist.] 1987, no writ). 
The California policy goes to the other extreme. Permitting a challenge at dissolution of all unilateral gifts during marriage certainly would allow a nondonor to challenge any gifts made at any time during the marriage. However, the California policy also permits a spouse (or executor) to challenge gifts made by the other spouse with the challenger's informal consent. California is in error, both substantively in requiring written consent and procedurally in tolling indefinitely all claims.

The Wisconsin policy is a compromise. A spouse is permitted to challenge at dissolution gifts made by the other spouse during marriage of which the challenger had no knowledge. This policy covers the situation where a spouse during marriage makes gifts and does not inform the other spouse, which seems a more sensible balance of competing concerns than that reflected in the policies of California or UMPA.

The Wisconsin provision does require the nondonor to act quickly to challenge an unreasonable gift. The spouse is expected to challenge the gift within one year of learning of it, even if the couple plans to stay married. ${ }^{325}$ Some would question whether this is a realistic model for couples. Spouses will often hesitate to challenge an unreasonable gift, in an effort to continue the marriage. The Wisconsin compromise undoubtedly will result in some injustices where false hopes of reconcilliation have caused valid claims to become timebarred. However, the compromise does seem to be the best way to obtain some finality and certainty for gifts by married people, while permitting challenges in situations when unreasonable unilateral gifts are most common. ${ }^{326}$

A fourth system, not accepted by any community property state, would permit an objecting spouse to bring suit during marriage against the other spouse, but would not force the spouse to litigate the claim during marriage. The objecting spouse would be given the choice to sue during marriage or to wait and challenge the gift at dissolution. This system seems to be a small improvement over the rule now accepted by most community property states, which requires spouses to challenge all unilateral gifts at dissolution. Some might argue that the current majority approach reduces spousal strife during an intact marriage. However, it is not clear why barring a legal remedy for a disgruntled spouse will necessarily promote domestic harmony. An alternative explanation for the current system would be that it intends to encourage the objecting spouses to sue the donee (which the objecting spouse may do during marriage

325. In some other instances, a spouse must assert a claim during marriage or lose it. For example, a Texas case held that a spouse's tort claim against the other spouse for the transmission of herpes brought at the time of divorce was barred by the statute of limitations. Flores v. Lively, 818 S.W.2d 460 (Tex. Ct. App.-Corpus Christi 1991, writ denied). Also, in California a claim for reimbursement must be brought within a certain period after the objecting spouse learns of the expenditure. CAL. CIV. CODE $\$ 5120.210$. There is a split of authority regarding whether the applicable statute of limitations is tolled regarding a breach of a prenuptial agreement during marriage. Pursuant to the majority rule, the statute is tolled. See Judith T. Younger, Perspectives on Antenuptial Agreements: An Update, 8 J. AM. ACAD. MATRIM. LAW. 1, 7-8 (1992).

326. A more equitable solution would be to give the objecting spouse two years after notice of the gift to decide whether to sue. 
in all states other than Texas), and the focus of the dissatisfaction, therefore, will be on the donee and not the donor spouse.

The Wisconsin provision has no absolute cutoff date for when unilateral gifts may be challenged; any such gift may be challenged, regardless of when it occurred, as long as the challenger had no prior notice of it. It may be useful to establish some absolute cutoff date for unilateral gifts without regard to whether the nondonor had notice. On one hand, it does seem unfair to contemplate barring a spouse with no notice from challenging a unilateral gift. However, notice will often be difficult to prove, because most evidence will be in the form of one spouse's recollections of conversations or whether the other spouse looked at the checking account statement for a particular month. Notice will be even more difficult to establish regarding gifts made long ago. It, therefore, might be sensible to bar all challenges of unilateral gifts made more than five years before dissolution. Unfortunately, this rule would bar challenges of some improper unilateral gifts made without notice to the other spouse. However, such a rule would also bar a spouse from fraudulently challenging gifts of which the challenger actually had notice and informally approved. ${ }^{327}$

IV

Duties of a Managing SPOUSE

\section{A. Should a Manager Be Considered a Trustee?}

If both spouses join in a transaction, no breach of duty claim usually arises, at least where both have participated and neither relied on the other to look out for the community's interest. ${ }^{328}$ Questions involving duty of care frequently arise in connection with unilateral management transactions or when one spouse refuses to agree to a reasonable joint-management transaction proposed by the other. When one spouse acts on behalf of the community, such actions obviously can affect the community interest of the other spouse in the property. These situations present the issue of what standard of care is applicable to the managing spouse. Courts, legislators, and commentators frequently make utterances such as "spouses are fiduciaries" duties of those in a confidential relationship." ${ }^{330}$ However, it is not clear what

327. In Texas, the donee must first attempt to recover from the donor at dissolution. The statute of limitations, therefore, must also be tolled for the action against the donee. See Carnes v. Meador, 533 S.W.2d 365 (Tex. Civ. Ct. App.--Dallas 1975, writ refd n.r.e.).

328. A spouse could still be liable if the spouse makes a misrepresentation or acts fraudulently.

329. Vai v. Bank of America, 15 Cal. Rptr. 71 (Cal. 1961); Compton v. Compton, 612 P.2d 1175, 1182 (Idaho 1980) (referring to the fiduciary duty of spouses); Roselli v. Rio Communities Service Station, 787 P.2d 428 (N.M. 1990); Miller v. Miller, 700 S.W.2d 941, 945 (Tex. Ct. App.-Dallas 1985, writ ref'd n.r.e.) (referring to the fiduciary duty one spouse owes the other); In re Marriage of Matson, 730 P.2d 668,671 (Wash. 1986) (referring to fiduciary duty of spouses). The new California statute states that spouses have a "fiduciary relationship." CAL. CIV. CODE ANN. $\$ 5103$ (West 1991).

330. Harold E. Verrall \& Gail B. Bird, California Community Property 378 (5th ed. 1988). 
these statements should or do mean in the context of a spouse's decisions regarding the management of community property. These purported rules have been further complicated by other statements by courts and legislatures to the effect that spouses need only act "in good faith." 331

One model for fiduciary responsibility is found in trust law, where fairly clearly defined rules exist regarding duties of care and the scope of permissible investment. ${ }^{332}$ The trust model, however, has not proved useful for marital property rights purposes. On reflection, the behavior expected of trustees differs markedly from what society would expect of spouses. Trustees are expected to keep detailed records. More importantly, trustees are expected to invest conservatively and act like prudent persons. ${ }^{333}$ Trustees are held to these standards for at least two reasons: First, they are experienced managers being paid for managing; and, second, the trustee has no financial interest in the trust corpus, and the trustee's compensation normally is not tied to increases in value of the corpus. An "agency problem" therefore exists, and some means must be found to encourage the trustee to further the interests of the trust beneficiary. ${ }^{334}$ A spouse managing community property is situated quite differently from a trustee. The spouse has a fifty percent interest in the "corpus" being managed, so the manager's financial interests are tied to the interests of the "beneficiary"-the other spouse-and no additional mechanism is needed to accomplish this result. ${ }^{335}$ Also, the spouse is not compensated for managing community property and might not have much management experience, so the rules created for trustees are inappropriate. ${ }^{336}$

Most courts have reached the sensible conclusion that a spouse must satisfy only a duty to act in good faith when managing the community estate. ${ }^{337}$ This seems to mean merely that the spouse must not intentionally deplete the estate.

331. E.g., WIS. STAT. ANN. $\$ 766.15$ (West 1983).

332. In fact, when some courts have gotten a bit carried away they have referred to a managing spouse as a "trustee." See Spector v. Spector, 382 P.2d 659 (Ariz. 1983); Vai v. Bank of America, 15 Cal. Rptr. 71 (Cal. 1961); Baker v. Baker, 67 Cal. Rptr. 523 (Cal. Ct. App. 1968); Fields v. Michael, 205 P. 402, 405 (Cal. Ct. App. 1949).

333. See In re Newhoff, 486 N.Y.S.2d 956 (N.Y. App. Div. 1985); Paul G. Haskell, The Prudent Person Rule for Trustee Investment, 69 N.C. L. REV. 87 (1990).

334. See Kenneth B. Davis, Jr., Judicial Review of Fiduciary Decisionmaking, 80 Nw. L. REV. 1, 4 (1985); Eugene F. Fama, Agency Problems and the Theory of the Firm, 88 J. POL. ECON. 288 (1980).

335. Professor Anderson has discussed that a partner has a strong incentive to maximize the value of the firm, because he has an equity interest. Alison S. Anderson, Conflicts of Interest, 25 UCLA L. REV. 738, 771 (1978).

336. See Williams v. Williams, 92 Cal. Rptr. 385 (Cal. Ct. App. 1971) (stating that a spouse does not have to keep detailed financial records throughout the marriage).

337. See U.M.P.A. \$2. The comment to that section states that a spouse is not a trustee. LA. CIV. CODE ANN. art. 2354 (West 1979) provides that a spouse is liable for loss or damage caused by fraud or bad faith. See also Cross, supra note 202, at 541-42 (stating that the duty of the manager was to act in good faith). Bank of California v. Connolly, 111 Cal. Rptr. 468 (Cal. Ct. App. 1973), decided before the 1991 management amendments to the California statutes, accepts that it is appropriate to apply a good faith standard to a managing spouse. Even after the amendments, it is clear that California does not accept the trustee "prudent person" standard for a manager. See CAL. CIV. CODE ANN. \& 5103(b). WIS. STAT. ANN. $\S 766.15$ states that spouses must act in good faith. $C f$. infra notes $343-46$ and accompanying text, which suggest that Wisconsin and California might apply a negligence standard. 
For example, in Andrews v. Andrews, ${ }^{338}$ a Texas case where the wife claimed that her husband had violated his management duties to the community by making unsuccessful investments in real estate that caused the community to lose money, the court concluded that a spouse will not be liable for an "unwise" investment made in good faith. ${ }^{339}$

Most investments are made in good faith. For example, Hauge v. Hauge $e^{340}$ involved a divorce where the wife challenged the husband's investments of community property in horses. Although the community estate lost $\$ 200,000$, the court found that these investments were made in good faith. The court emphasized that the husband received professional investment advice and that the investment was "not like Las Vegas gambling." The court cannot mean that a spouse must consult an investment adviser before making an investment decision. The court implies that a manager must satisfy a duty of care, and that if the spouse consulted an investment adviser this would be relevant to that determination. ${ }^{341}$

The new California provision ${ }^{342}$ states that the relationship of the spouses is a "fiduciary relationship subject to the same rights and duties of nonmarital business partners ...."343 Some cases have held that, among other things, in a commercial partnership, a partner is liable for damages caused by his negligence, without regard to good faith. ${ }^{344}$

338. 677 S.W.2d 171 (Tex. Ct. App.-Austin 1984, no writ)

339. Id. at 175 . Note that in Texas, real estate transactions are joint management transactions only to the extent of sale or encumberance of the home, unless the transaction is a joint management transaction pursuant to sections 5.22(b) or 5.22(c) of the Texas Family Code.

340. 427 N.W.2d 154 (Wis. Ct. App. 1988).

341. In Marriage of Rapp, 392 N.W.2d 129 (Wis. Ct. App. 1986), the court held that the wife should be charged with a loss of $\$ 7500$ where it was due to her "deliberate neglect" of a business she managed.

342. Cal. Civ. Code ANN. \& 5103(b).

343. Id.

344. Wyler v. Feuer, 149 Cal. Rptr. 626 (Cal. Ct. App. 1978); Shinn v. Thrust IV, 786 P.2d 285 (Wash. Ct. App. 1990) (partner has a duty to act like an ordinarily prudent person). See generally Norwood P. Beveridge, Jr., Duty of Care: The Partnership Cases, 15 OKLA. CITY U. L. REV. 753 (1990). Cf. Ferguson v. Williams, 670 S.W.2d 327, 331 (Tex. Ct. App. 1984) (reh'g denied) (partner should not be liable for negligent mismanagement); 2 ALAN R. BROMBERG \& LARRY E. RIBSTEIN, BROMBERG AND RIBSTEIN ON PARTNERSHIP \$ 6.07, at 6:85 (1988) (arguing that a partner should not be liable for negligence). Another commentator states that a partner has not been liable for negligence, as distinguished from "'culpable negligence,' bad faith or fraud." See John L. Ale, Substantive Law and Special Problems of General and Limited Partnerships, ReSOURCE MATERIALS-PARTNERSHIPS 40 (9th ed. ALI 1990). See also Note, Fiduciary Duty of Partners, 48 IowA L. REV. 902 (1963) (concluding that a partner is subject to a duty not to act with gross negligence).

Marriage of Beltran, 227 Cal. Rptr. 924 (Cal. Ct. App. 1986) involved a postdivorce dispute. The employee-spouse was in the military, and the divorce court had granted the other spouse a portion of the military retirement, to be received when the employee retired. After divorce, the employee was convicted of child molestation and given a dishonorable discharge. As a result, he lost his entitlement to military retirement benefits. The court determined that this loss was due to "dissipation" of the community for which the employee-spouse should reimburse the other spouse. The court did not explain its rationale in any detail. It may be based upon the idea, developed later in this article, that a spouse should be liable for the costs to the community of criminal activity.

In contrast, Marriage of Schultz, 164 Cal. Rptr. 653 (Cal. Ct. App. 1980), involved another spousal dispute regarding negligence. Here the husband was sued on a debt. He did not retain a lawyer and did not inform the court of his new address. He did not, therefore, receive notice of the hearing, did 
During an intact marriage, it would be undesirable to impose liability for mere negligence upon a manager spouse. ${ }^{345}$ The good faith standard is sufficient. The spouse has a fifty percent interest in the property and has a strong incentive not to dissipate it. Even if a spouse is negligent and the community suffers a loss, this risk is a cost that should be borne by the community. If a spouse does something brilliant, the other shares in any financial reward. Losses due to a spouse's negligence are also appropriately charged to the community. In other contexts, no one contends that a spouse should reimburse the community for losses suffered due to that spouse's negligence. For example, if one spouse negligently causes a car accident driving to work or commits professional malpractice, the tortfeasor is not liable to the community for any losses. ${ }^{346}$

If a spouse acts in bad faith, of course, liability should result. For example, a spouse who knows that an investment is a poor business decision, but invests to help a friend or lover, is acting in bad faith. Similarly, intentional destruction of community property by the spouse is considered bad faith. ${ }^{347}$ To satisfy the duty of good faith, a spouse must act with the primary goal of benefitting the community. ${ }^{348}$

The claims in cases such as Andrews and Hauge, however, are very different. In these cases, the nonmanager is arguing that liability to the community should result because the manager made a bad investment decision. All would agree such decisions occur. Indeed, spouses appearing in divorce court frequentiy have made more than their share of such decisions; the ramifications of these decisions may be one of the principal reasons the parties are divorcing. In what situations of this type, if any, should the manager be liable?

Bad financial decisions can cause great burdens on a marriage. However, the wisdom or fairness of holding a manager spouse liable for bad investment decisions is questionable, even if he or she might be considered negligent. Spouses fairly frequently make unilateral decisions regarding risky investments. Some are successful; some are not. Some investments undoubtediy are made

not attend, and a default judgment was entered against him. In a later divorce action, the wife claimed that, due to the husband's negligence regarding the prior legal action, he should bear the full cost of this judgment. The court disagreed and stated that this should only occur if the husband "misappropriated" community funds; negligence was not a sufficient ground to invoke this principle.

345. For a different opinion regarding the desirability of a duty of care in intact marriages, see Janet M. Riley, Women's Rights in the Louisiana Matrimonial Regime, 50 TUL. L. REV. 557,570 (1976). Professor Riley suggests that a manager spouse should be considered a fiduciary, held to the standard of a prudent administrator. Id. This would be at least a negligence standard and sounds very similar to the "prudent person" standard for a trustee.

346. See REPPY \& SAMUEL, supra note 1 , at $\$ 17$.

347. See People v. Schlette, 293 P.2d 79 (Cal. Ct. App. 1956). A spouse was also found liable for mismanagement in Marriage of Steadman, 821 P.2d 59, 62 (Wash. Ct. App. 1991) (emphasizing the spouse's "gross fiscal improvidence") and Kyson v. Kyson, 596 So.2d 1308 (La. Ct. App. 1991) (where the managing spouse terminated a lease benefitting the community, and could give no reason why he did it).

348. This will normally mean that the spouse intends to make a profit for the community. Of course, in some instances a spouse might attempt to minimize losses or obtain a tax advantage; this would still be action in good faith. 
after little reflection or investigation and are later regretted. Still, the benefit of successful investments rashly made accrues to the community, so it does not seem unfair to charge the community for those that are unsuccessful. In addition to the decisions in Andrews and Hauge, a number of courts have agreed with the contention that a spouse should not be liable for negligent management. ${ }^{349}$

The good faith standard proposed in this article to govern a spouse's investment decisions resembles the "business judgment rule" approach utilized by many courts to determine if a director is liable to the corporation for a decision allegedly detrimental to it. This rule essentially holds a director liable only if it is established that there was "fraud, illegality or a conflict of interest." 350 In addition, courts will sometimes cursorily review the merits of the decision, attempting to determine whether any rational person could have considered the director's decision to be in the best interests of the corporation, viewing the decision in light of the circumstances at the time the decision was made. ${ }^{351}$ The court does not attempt to determine whether the decision was reasonable or negligent.

If, at divorce, a spouse is permitted to recover for losses due to the other's negligent management, one shudders to think what effect this would have on the dissolution process, particularly if all investments during marriage could be challenged. It could facilitate an undesirable escalation of hostilities during divorce. Many couples dissolving their marriages have been financially unsuccessful during the marriage. Absent extraordinary circumstances, it would be unwise to allow the spouses to fight about who might have been the most blameworthy.

Holding a spouse liable for negligent management of community property could encourage a spouse either to make investment decisions jointly or to make

349. See, e.g., Williams v. Williams, 92 Cal. Rptr. 385, 388 (Cal. Ct. App. 1971) (in dictum) ("[A]lthough a trustee or fiduciary might be personally liable for a loss sustained by virtue of an improvident investment in speculative stock, we question whether a [manager] is liable to [the other spouse] for a loss sustained under these circumstances."); Cabral v. Cabral, 534 So.2d 952 (La. Ct. App. 1989) (Although the managing spouse "might have been more attentive" to an investment, he was not liable for losses suffered by the community because there was no evidence of fraud or bad faith.). An appellate court in a common law state, Gentile v. Gentile, 564 So.2d 820 (Fla. Ct. App. 1990), has also rejected the argument that a managing spouse should be liable for unsuccessful investments during marriage. See Geddes v. Geddes, 530 So.2d 1011 (Fla. Ct. App. 1988). See also the following student comment that was approved by a California court:

Evidently a [manager] is free to make unwise purchases, to speculate freely in ... securities, or to sell personal property foolishly without the [other spouse's] consent, for in these situations the desirability of freely transferable personal property is thought to outweigh the harm suffered by the [other spouse].

Note, Wife Recovers Husband's Gambling Losses, 9 STAN. L. REV. 400, 404 (1957), cited in Bank of California v. Connolly, 111 Cal. Rptr. 468, 487 (Cal. Ct. App. 1973).

350. See, e.g., Shlensky v. Wrigley, 237 N.E.2d 776 (IIl. Ct. App. 1968) (the conduct of the director "must border on" one of these elements).

351. For a discussion of a director's liability for a breach of a duty of care, see generally, Charles Hansen, The ALI Corporate Governance Project: Of the Duty of Due Care and the Business Judgment Rule, 41 BUS. LAw. 1237 (1986); Kenneth E. Scott, American Law Institute and the Corporate Governance Project, 35 STAN. L. REV. 927 (1983); Elliott J. Weiss, Economic Analysis, Corporate Law, and the ALI Corporate Governance Project, 70 CORNELL L. REv. 1 (1984). 
more conservative decisions; and some might argue that either would be a beneficial result. However, the threat of liability could discourage high-risk, high-profit unilateral investments and might not benefit the community in the long run. ${ }^{352}$ It might be wise to add to the good faith standard proposed here a "recklessness" limit, so that a particularly egregious unilateral investment decision would be actionable, even if the spouse acted in good faith. ${ }^{353}$ A recklessness standard is theoretically more difficult to satisfy than a negligence standard. ${ }^{354}$ One might argue that such a standard would reflect an appropriate balance between attempting to safeguard the property interest of the nonmanaging spouse and attempting to avoid placing an unreasonable burden upon a manager spouse. It is doubtful, however, that courts and juries would limit such awards to truly egregious situations. In hindsight, many bad investment decisions appear at least stupid, if not reckless. ${ }^{355}$ Therefore, it seems unwise to endorse any standard that would result in liability for unilateral investment decisions made in good faith, even those later determined to be grossly negligent or reckless.

If any court or legislature determines that a manager spouse should be governed by some standard higher than good faith, consideration should be given to recent corporate law developments in Delaware. In Smith v. Van Gorkum, ${ }^{356}$ the Delaware Supreme Court held that when making important decisions, directors must adhere to a reasonable decisionmaking process. The court focused not on the merits of the decision, but on the process itself, apparently concluding that a decision is less likely to be ill-informed if made after reasonable investigation and contemplation. This standard is a compromise between the position of those who wanted to review the reasonableness of the merits of the directors' decision and those who merely wanted to hold directors to a standard of good faith. Under the Smith standard, directors are strongly encouraged to make decisions pursuant to a reasonable process but are spared the specter of a judge second-guessing the merits of the decision. ${ }^{357}$

352. See Bank of California v. Connolly, 111 Cal. Rptr. 468 (Cal. Ct. App. 1973); Note, The Husband's Fiduciary Duty-More Protection for the California Wife, 14 STAN. L. REv. 587, 598-99 (1962). For a discussion of why an investment involving more risk could in some circumstances be a better investment than one involving less risk, after considering the likelihood of various outcomes, see generally WILlIAM A. KLEIN, BuSINESS ORGANIZATION AND FINANCE 147-49 (1980).

353. The drafters of the Revised Uniform Partnership Act decided that a partner should be liable to the partnership for grossly negligent or reckless conduct. R.U.P.A. \& 404(d).

354. Under the Second Restatement of Torts, "recklessness" is more than "mere inadvertence, incompetence, unskillfulness, or a failure to take precautions .... [T] recognize [or should have recognized] that his conduct involves a risk substantially greater in amount than that which is necessary to make his conduct negligent." RESTATEMENT (SECOND) OF TORTS $\$ 500$ cmt. g.

355. For example, in Litwin the court held that the directors' decisions were "so improvident, so risky, so unusual and unneccessary as to be contrary to fundamental conceptions of prudent banking practice." Litwin v. Allen, 25 N.Y.S.2d 667, 699 (Sup. Ct. 1940). It seems that the court's view is grounded firmly in hindsight and gives inadequate weight to the fact that the loan transaction from which the dispute evolved was completed just before the stock market crash in October/November 1930.

356. 488 A.2d 858 (Del. 1985).

357. See S. Samuel Arsht, The Business Judgment Rule Revisited, 8 HOFSTRA L. REv. 93 (1979). 
If spousal management decisions are to be subject to a standard higher than that of good faith, the Smith rule would be preferable to a negligence standard based upon the merits of the decision. Neither is desirable, however. Smith has not had a uniformly enthusiastic reception, even among corporate commentators. ${ }^{358}$ Its application to spouses is even more problematic. Spouses may not have as much business or investment experience as directors and are not compensated for management of the marital estate. Also, in contrast to the position of directors, spouses have a financial interest in the value of the community estate and thus require no additional incentive to maximize its value.

Even if one accepts that a manager should be liable for negligence, the new California policy remains puzzling. Under the new statute, a unilateral sale of community property for less than its fair and reasonable value requires the written consent of the other spouse. ${ }^{359}$ This seems to mean that the manager will be liable for selling community property for less than market value, regardless of whether the manager was negligent. ${ }^{360}$ This policy seems quite harsh and undesirable.

358. See, e.g., Daniel R. Fischel, The Business Judgment Rule and the Trans Union Case, 40 Bus. LAW. 1437 (1985); Leo Herzel \& Leo Katz, Smith v. Van Gorkom: The Business of Judging Business Judgment, 41 BUS. LAW. 1188 (1986).

359. CAL. Civ. CODE ANN. \& 5125(b) (West Supp. 1992).

360 . Most courts agree that the nondonor spouse may sue the donor for the value of gifts made unilaterally that required joint action. See supra notes $289-94$ and accompanying text. 


\section{B. Consumption Decisions}

1. In General. A spouse traditionally has not been liable to the community for unilateral consumption decisions. This rule undoubtedly stems from a sensible judicial unwillingness to resolve, at divorce or at any other time, disagreements between spouses about spending marital funds.

Unilateral decisions regarding consumption expenditures present different policy concerns from those arising relating to unilateral investment decisions. It was noted above that the spouses have similar interests regarding investments; each spouse wants to maximize the value of the community estate. In contrast, there is no congruence of interests regarding consumption decisions (unless one would say that each spouse is "interested" in seeing the other happy). One spouse might want to spend community funds on one thing, and the other might prefer another use of the funds. Also, consumption choices could benefit one spouse disproportionately, thus presenting the possibility that one spouse might try to usurp more than his or her share of the community. This suggests that some mechanism is needed to deter this from occurring. However, courts should not be asked to resolve every consumption disagreement. A sensible balance would be to permit a spouse unilaterally to use community funds for whatever purpose he or she considers desirable, unless the amount spent is grossly excessive, in light of the spouses' normal expenditures, needs, and the size of the community estate. ${ }^{361}$ If the amount spent is grossly excessive, however, the spending spouse should be liable to the community for the amount by which the expenditure exceeded a reasonable amount.

A spouse who objects to the other's consumption decisions does have some available remedies. If the spouse is having difficulty exercising equal management rights over the community estate, in Wisconsin, California, and possibly other states, the objecting spouse could bring an "add-a-name" action. ${ }^{362}$ Alternatively, the unhappy spouses may wish to have the community estate partitioned into two separate estates. ${ }^{363}$ Finally, mediation may also be a useful remedy in these situations.

2. Gambling, Drinking, and Drug Use. If a spouse gambles with community funds and loses, the loss creates a management issue. In Hauge v. Hauge, ${ }^{364}$ as noted above, the Wisconsin court justified its refusal of a remedy to the objecting spouse by noting that, among other things, the other spouse's equine investment was not like Las Vegas gambling. ${ }^{365}$ It is interesting to consider why this is significant. Presumably all but the most neurotic gamblers try to win.

361. Professors DeFuniak and Vaughn state that "immoderate or excessive wasting" of the community would give rise to a claim, at least under Spanish law. WILLIAM Q. DEFUNIAK \& MICHAEL J. VAUGHN, PRINCIPLES OF COMMUNITY PROPERTY 295-96 (1943).

362. See supra notes $97-101$ and accompanying text.

363. See supra note 124-26 and accompanying text.

364. 427 N.W.2d 154 (Wis. Ct. App. 1988).

365. Id. at 156. 
Is not the risky investment a use of community funds intended "in good faith" to enhance the community? ${ }^{366}$ Indeed, it may be difficult to state any meaningful distinction between gambling and a risky stock market investment. ${ }^{367}$

Few cases discuss whether a spouse breaches a duty to the other spouse if community funds are "dissipated" on drugs or alcohol. ${ }^{368}$ This expenditure is not an "investment" of community funds, but a consumption decision. ${ }^{369}$ Courts rarely have held a consumption decision during an intact marriage to be a breach of duty, even if one spouse spends community funds on things that do not benefit the other spouse. ${ }^{370}$ Still, the amounts that could conceivably be spent on drugs could be very high, higher than most other types of consumption expenditures. Therefore, courts might be inclined to find this type of consumption to be a bad faith expenditure if the amount spent was sufficiently great. ${ }^{371}$ Alternatively, drug addiction and alcoholism could be treated as diseases for which the spouse should not be penalized. ${ }^{372}$

Damage to the community from gambling, drinking, or drug use should be treated like any other consumption decision. In other words, losses would not be actionable unless the amount expended was grossly excessive, in light of the needs of the family and the size of the community estate. ${ }^{373}$ This approach

366. Another commentator has stated that under early Spanish community property law, the manager was not responsible to the community for "losses due to debauchery, gambling and dissolute living." See Nina Nichols Pugh, The Spanish Community of Gains in 1803: Sociedad de Gananciales, 30 LA. L. REV. 1,14 (1969).

367. One writer has noted that pure gambling, like a lottery, requires no skill, while a speculative stock investment at least is based upon some opinion about future economic prospects. REUVEN BRENNER, GAMBLING AND SPECULATION 90 (1990).

368. A Wisconsin court has stated that a spouse should be solely responsible for losses to the community due to "excessive" drinking. Anstutz v. Anstutz, 331 N.W.2d 844, 846 (Wis. Ct. App. 1983). Marriage of Clark, 538 P.2d 145 (Wash. Ct. App. 1975), held that a divorce court could consider, in connection with deciding what would be an equitable division of the parties' assets, that one spouse had dissipated a substantial amount of commmunity funds on alcohol. In some cases in common law states, expenditures of marital funds for drinking or drugs have been deemed "fault" that could affect the property division. See Mosley v. Mosley, 601 A.2d 599 (D.C. Ct. App. 1992); Yount v. Yount, 821 S.W.2d 876, 881 (Mo. Ct. App. 1991).

369. Many argue that gambling is also an entertainment expense, a consumption decision rather than an investment.

370. See supra text accompanying note 361 .

371. For an alternative theory of reimbursement, see infra notes 374-75.

372. Ira Berkow, The Pitcher's "Psychiatric Disorder," N.Y. TIMES, Nov. 21, 1992, at 12, col. 2 (discussing whether drug addiction is a mental illness). The same argument might be made about gambling. See Michel Marriott, Fervid Debate on Gambling: Disease or Moral Weakness?, N.Y. TIMES, Nov. 21, 1992, at 1 col. 5 .

373. For example, in Reaney v. Reaney, 505 S.W.2d 338 (Tex. Civ. Ct. App.-Dallas 1974, no writ), a spouse was held liable at divorce for losing $\$ 53,000$ via gambling and other activities. The same result was reached in Siegel v. Siegel, 574 A.2d 54 (N.J. Super. Ct., Ch. Div. 1990), where a spouse lost $\$ 227,850$ gambling. The Wisconsin court said in Anstutz, 331 N.W.2d at 846 , that a spouse should be liable for excessive gambling losses. The wife in the movie Lost in America would certainly be liable for her gambling losses pursuant to this analysis.

In a divorce case in a common law state, the court held that a spouse should not be liable for dissipation where it was established that the spouse spent a small amount of marital funds drinking in bars. Marriage of Adams, 538 N.E.2d 1286 (IIl. Ct. App. 1989).

In Rosenfeld v. Rosenfeld, 597 So. 2d 835, 837-38 (Fla. Ct. App. 1992), the divorce court rejected the wife's contention that the husband should be responsible for gambling losses during marriage, 
would avoid testimony about private, embarrassing moments of the spouses' married life, except where the loss to the community was substantial. This compromise seems to reflect a good balancing of the relevant competing policies.

In addition to the above approach, courts should distinguish between lawful and unlawful activities. If a spouse engaged in an unlawful activity, it would be considered bad faith, in light of the potential losses to the community due to fines, legal fees, and lost wages upon incarceration. Under this approach, a spouse would be liable for losses stemming from unlawful activities, regardless of the amount lost. Therefore, a spouse could spend a large (but not grossly excessive) amount of community funds drinking or gambling without incurring liability, because such activities generally are lawful. ${ }^{374}$ Any amount spent on drug use would be actionable, however, because drug use is unlawful. There is some precedent for the argument that a spouse should be liable to the community for losses due to criminal wrongdoing. ${ }^{375}$

Marriage of Stitt ${ }^{376}$ involved a divorce of a couple where one of the spouses had been convicted of embezzlement during the marriage. In its decision, the court concluded that the community should not be liable for the spouse's legal fees in connection with the embezzlement. The court emphasized the criminal nature of the wrongdoing.

In Bergman v. State, ${ }^{37}$ the husband was convicted of arson. The state attempted to collect court costs awarded the state in the prosecution from the spouses' community property, but the court held that the community was not liable. The court emphasized the criminality of the husband's behavior and decided that it was not done in furtherance of any community benefit. ${ }^{378}$

In Louisiana, a spouse usually need not reimburse the community for any loss suffered due to that spouse's torts. However, if the community suffers a loss due to a spouse's intentional tort, and the tort is unrelated to the community, the

because the wife had "participated" in the gambling.

374. Of course, gambling is illegal in many states. In some states no gambling is legal, while in others only certain types are legal. See, e.g. Novo v. Hotel del Rio, 205 P.2d 576 (Cal. Ct. App. 1956); see also infra cases cited in note 378 .

375. For example, the result in Marriage of Beltran, 227 Cal. Rptr. 924 (Cal. Ct. App. 1986), could be justified by the theory set forth in this paragraph.

376. 195 Cal. Rptr. 172 (Cal. Ct. App. 1983).

377. 60 P.2d 699 (Wash. 1936).

378. Id. at 701. But see Villescas v. Arizona Copper Co., 179 P. 963 (Ariz. 1919), where the Arizona Supreme Court held the community liable for a fine against the husband. One could attempt to distinquish Villescas from the other cases. If the husband in Villescas worked outside the home, the community benefitted from paying the fine, in that the husband was able to avoid incarceration and, thereby, to continue working. Thus, if it is assumed that the husband had the option of going to jail or paying a fine, it may have been best for the community for him to pay the fine. Still, on balance it appears that Villescas is wrong; thus, courts should follow Bergman, Stitt, and Beltran.

This issue has arisen in a common law state. In Andrea v. Andrea, 575 N.Y.S.2d 240 (N.Y. Sup. 1991), the husband, a police officer, was arrested for larceny shortly before the divorce. He was convicted and, as a result, lost his entitlement to a police pension. The wife argued that this should be considered dissipation for which the husband should reimburse the marital estate. The court concluded that this was not dissipation, because the husband did not intend to damage the marital estate by his actions. The husband therefore did not have to reimburse the marital estate. 
community can obtain reimbursement from the tortfeasor. ${ }^{379}$ This liability for intentional torts unrelated to the community could be analogized to losses due to criminal activities.

\section{The Duty to Account for Missing Community Property}

At dissolution, courts do not require a spouse to account for all community money handled during the marriage. ${ }^{380}$ However, if a valuable asset disappears on the eve of a filing of a divorce action, a different policy is appropriate. If only one spouse had access to the property, courts will place the burden upon that spouse to verify that the property was used for appropriate purposes, such as family living expenses. ${ }^{381} \mathrm{~A}$ spouse who cannot do so is properly charged for the value of the asset. ${ }^{32}$ This treatment of assets that have disappeared when the marriage breaks down stems from the common-sense concern that a spouse might be tempted to hide, or possibly dissipate, community assets before the assets are divided..$^{383}$

\section{Is a Unilateral Action in Violation of Joint Management Rules a Breach of Duty?}

All states require some community property transactions to be made jointly. Despite these rules, a spouse may try to conduct such transactions unilaterally, sometimes incurring significant damage to the community. If the objecting spouse challenges the transaction before the closing of the deal, the transaction will not be completed and the spouses may need only to reimburse a third party for out-of-pocket costs. ${ }^{384}$ However, if the objecting spouse does not learn of

379. LA. Crv. CODE ANN. art. 2363 (West Supp. 1992).

380. See Williams v. Williams, 92 Cal. Rptr. 385 (Cal. Ct. App. 1971). The new California statute provides that "nothing in this section is intended to impose a duty for either spouse to keep detailed books and records of community property transactions." See CAL. CIV. CODE \$ 5103(b)(2) (West 1991). This probably only restates the Williams rule. However, one might argue that, based upon the use of the word detailed, a spouse now inferentially has a duty to keep some records. Such a rule would be unwise.

381. See Marriage of Cohen, 164 Cal. Rptr. 672 (Cal. Ct. App. 1980).

382. See LA. CIV. CODE ANN. art. 2369 (West 1985); Marriage of Valle, 126 Cal. Rptr. 38 (Cal. Ct. App. 1975); Linton v. Linton, 303 P.2d 905 (Idaho 1956); Arrington v. Arrington, 613 S.W.2d 565 (Tex. Civ. Ct. App. - Fort Worth 1981, no writ.); Grothe v. Grothe, 590 S.W.2d 238 (Tex. Civ. Ct. App. Austin 1979, no writ). It is unclear whether punitive damages would be possible in such situations. See supra notes 305-07 and accompanying text.

Common law equitable distribution states apply a similar notion of dissipation to a manager's duty when a marriage is breaking down. E.g. Schneider v. Schneider, 824 S.W.2d 942 (Mo. Ct. App. 1992).

383. See Adams v. Jensen-Thomas, 571 P.2d 958 (Wash. Ct. App. 1977).

Professor Anderson has pointed out that, although in a commercial partnership the partner's equity interest reduces the partner's temptation to cheat, at dissolution the partner might have a stronger incentive to engage in cheating. (This incentive to cheat would increase if the partner assumes that the partnership's activities at the time of dissolution are not going to be carefully scrutinized by a court, or if the partner is not deterred by that possibility.) Alison Grey Anderson, Conflicts of Interest: Efficiency, Fairness and Corporate Structure, 25 UCLA L. REV. 738, 771 (1978).

384. See Nicaud v. Fonte, 503 So.2d 79 (La. Ct. App. 1987). 
the transaction until after the closing, the cost to the community could be much greater. ${ }^{385}$

Should a unilateral action by a spouse in violation of joint management be a violation of a spouse's duty to the other, creating a right to recover damages? One factor that gives pause is that a spouse might not be aware of the joint management rules. However, in some cases it is clear that the spouse has notice of the rules. When this is established, in cases involving failure to obtain the consent of one spouse, it does seem reasonable to hold the involved spouse liable for any damage to the community. ${ }^{386}$ In Webb $v$. Pioneer Bank \& Trust $\mathrm{Co} .{ }^{387}$ one spouse refinanced a loan on community realty by forging the other's signature. The objecting spouse obtained a judgment against the signing spouse for the amount of the loan not used to pay off the prior loan, and also recovered damages for mental anguish.

\section{E. The Suit To Recover for a Breach of Duty}

The UMPA and Wisconsin both provide that a spouse can recover for a breach of duty by the other spouse whenever the objecting spouse's property interest has been harmed. ${ }^{388}$ California initially required "substantial" damage. ${ }^{389}$ The revised California provision deleted this requirement; an objecting spouse may now recover whenever there has been or will be an "impairment to" or "detrimental impact" on the objecting spouse's property interest. ${ }^{390}$ The original California limit presumably was added to ensure that court calendars would be burdened only by disputes pertaining to a substantial amount of money. Drafters of the current revisions must have convinced the legislators either that the initial limit was unfair, or that the proposed change would not significantly increase the number of cases filed.

Under the Wisconsin provision, a spouse must bring suit within six years after he receives notice of the facts relating to the breach. ${ }^{391}$ In California, the action must be brought within three years after the spouse learns the facts;

385. See Mark v. Title Guarantee \& Trust Co., 9 P.2d 839 (Cal. Ct. App. 1932).

386. A cotenant has been held liable for conversion when one has sold personalty without the consent of the other cotenant. Stitt v. Felton, 7 A.2d 371 (Pa. Super. Ct. 1939).

A conversion standard for damages would not be advisable in this situation. Under that standard, the spouse would be liable for half the value of the property affected. Instead, the spouse acting unilaterally should be liable for damage to the community by the action. A claim for intentional infliction of emotional distress also would seem possible. See Twyman v. Twyman, 1993 WL 141139 (Tex. 1993).

387. 530 So. 2d 115 (La. Ct. App. 1988).

388. See CAl. Civ. Code ANN. \$ 5125.1 (West Supp. 1992); WIs. Stat. ANN. $\$ 766.70$ (West 1983); U.M.P.A. \& 15. The Wisconsin and U.M.P.A. provisions require a breach of duty of good faith that results in damage to the other's property; California now requires a breach of fiduciary duty that results in an impairment to the other's interest.

389. See Bruch, supra note 55, at 750.

390. CAL. CIV. CODE ANN. $§ 5125.1$ (as amended effective 1991).

391. WIS. STAT. ANN. $\S 766.70$ (West 1983). The U.M.P.A. limit is three years. U.M.P.A. $\$ 15$. 
however, the claim may be brought later in connection with the economic resolution of the dissolution of marriage. ${ }^{392}$

The recent California revisions made other changes to the provisions regarding remedies for a breach of a spouse's fiduciary duty. The law already permitted spouses to challenge at divorce any breach of duty, regardless of when it occurred or when the complaining spouse learned of it. ${ }^{393}$ Now, upon a showing of a breach of duty, the recent revisions seem to permit an objecting spouse to recover a minimum of fifty percent of the value of the property involved, plus attorneys' fees and costs, regardless of whether the objecting spouse suffered a financial loss. ${ }^{394}$ It is unclear why the drafters felt a need to award an objecting spouse more than the financial loss suffered, plus attorneys' fees. Another section seems to authorize punitive damages on a showing of fraud. $^{395}$ In all other cases, however, an amount equal to the financial loss suffered, plus attorneys' fees, is all that should be awarded to the objecting spouse.

\section{F. Is There Such a Thing as a Community Opportunity?}

If a spouse owns separate property, she frequently chooses whether to use community property or separate property when an investment is made. Some have questioned whether a spouse has a duty to make investments during marriage with community funds. ${ }^{396}$ This problem is fueled by statements that spouses are "partners." 397 Similarly, the new California provision states that "in transactions between themselves," spouses shall be "subject to the same rights and duties of nonmarital business partners, as provided in [s]ections . . . 15021 ... of the Corporations Code ...."398 Section 15021 of the California Corporations Code (section 21 of the Uniform Partnership Act), among other things, incorporates the notion of partnership opportunity.

A partner may not usurp a "partnership opportunity."399 In a commercial partnership, a partnership opportunity is one that relates to the partnership business. Many courts agree that an opportunity is only a partnership opportunity if the partnership has the financial wherewithal to take advantage of it. ${ }^{400}$ If a potential investment is a partnership opportunity and a partner

392. CAL. Civ. Code ANN. \& 5125.1 (West Supp. 1992).

393. Id. This right is subject to a claim of laches.

394. Id. $\$ 5125.1(\mathrm{~g})$. The statute is set forth in the text accompanying notes 114,115 . Compared to the California management provisions, the Internal Revenue Code is a model of clarity.

395. Id. \& 5125.1(h). Punitive damages have been awarded when one partner in a commercial partnership violates his fiduciary duty to other partners. Jerman v. O'Leary, 701 P.2d 1205 (Ariz. Ct. App. 1985).

396. See Donald R. Smith, Fiduciary Duty Between Spouses, TEX. BAR AdVANCEd FAM. L. CourSE ch. H (August 1988). See generally Ogden v. Ogden, 331 So. 2d 592 (La. Ct. App. 1976) (exercise of preemptive rights).

397. Weinberg v. Weinberg, 63 Cal. Rptr. 13 (Cal. 1967).

398. CAL. CIV. CODE ANN. \& 5103(b).

399. Meinhard v. Salmon, 164 NE 545 (N.Y. 1928).

400. E.g., Guth v. Loft, 5 A.2d 503 (Del. Ch. 1939). 
attempts to appropriate it for his own account, he must share the profit with the other partners.

It is difficult to understand how the notion of partnership opportunity could be useful to community property analysis. A potential investment is a partnership opportunity only if the agent learned of the opportunity while performing work on behalf of the principal. The business opportunity is, therefore, derived from the agency. The partner does not have to share profits from any other investments or opportunities, as long as the investment is not similar to those engaged in by the partnership. No analogous distinction exists for spouses; the scope of the community's "investment business" is limitless. From this perspective, every investment opportunity discovered or selected by a spouse during marriage would be a community opportunity, as long as there was sufficient community property (or credit) available at the time to fund the investment.

One way of attempting to resolve this problem would be to treat all investments during marriage as community opportunities. If one spouse desires to make an investment with separate property, the objecting spouse would have a right of first refusal. If the spouse given the right of first refusal declined to accept the investment, the other spouse could then invest separate property. ${ }^{401}$ This could be a workable solution if spouses could be trained to behave in this manner before every investment. It is unlikely that spouses would do so, however; generally, spouses probably would continue to invest separate property without obtaining the consent of the other spouse. If such investments occurred, the system would permit the objecting spouse to select, after the fact, which investments made with separate funds she would like the community to own. ${ }^{402}$ This result would not be fair.

The community opportunity concept is a solution looking for a problem. All potentially lucrative investments involve some risk. No one knows in advance which investments will be unusually successful. ${ }^{403}$ Therefore, an investor could not enrich his separate estate to the detriment of the community by selecting "guaranteed" investments for the investor's separate estate. Thus, as a general rule, it is appropriate to allow a manager to choose whether the separate estate or the community estate will bear the risk of a particular investment.

401. This is similar to the approach suggested in Klinicki v. Lundgren, 695 P.2d 906 (Or. 1985), a corporate opportunity case.

402. This result would follow because the investment would not have been made with the consent of the other spouse (so it would be a community opportunity, if the community chose to claim it).

403. Of course, if the spouse possessed inside information and knew a particular investment would be successful, this would present a community opportunity. This is obviously a very rare occurrence, however.

In other unusual instances, in may be clear that the return on a particular investment will be quite good. In such a situation, a community opportunity could also exist. See Marriage of Lucero, $173 \mathrm{Cal}$. Rptr. 680 (Cal. Ct. App. 1981) (involving a spouse's right to buy into a pension plan). 
This article assumes that a spouse has the right to devote some time to the maintenance of her separate estate without creating a community claim. ${ }^{404}$ Most spouses devote a minimal amount of time to investment decisions. Separate property investment decisions of this nature, involving negligible time and effort, should not create a community claim. ${ }^{405}$ If this approach is accepted, a separate property investment by a spouse normally would create no community claim (other than a claim for rents and profits generated by the investment). This policy represents an appropriate balance of interests. The community would have a claim to separate property investments only when a spouse devotes substantial time and effort to such investments. ${ }^{406}$ Professor Andrews seems to contend that every investment decision involving separate property creates a community claim, because it involves effort expended during marriage. ${ }^{407}$

The 1991 revisions to California law provide that the managing spouse will "[account] to the [other] spouse, and [hold] as trustee, any benefit or profit derived from any transaction by him or her without the consent of the other

404. See Somps v. Somps, 58 Cal. Rptr. 304 (Cal. Ct. App. 1967); Holloway v. Holloway, 671 S.W.2d 51 (Tex. Ct. App.-Dallas 1983, writ dism'd w.o.j.).

405. For example, the U.M.P.A. provides that a marital property claim arises only when one spouse devotes "substantial effort" to that spouses's individual property. U.M.P.A. $\$ 14$. If the spouse devoted a substantial amount of time to investments, the community should have a claim. However, as a general rule, it would not be useful to create a potential community claim arising from minimal time devoted to investment decisions. Should it really matter, for purposes of community property analysis, whether a spouse invests in a mutual fund or buys certain stocks after reading the Wall Street Journal?

In most situations, it will not matter whether this position or that of Professor Andrews' governs. Even under Professor Andrews' analysis, Van Camp normally should be used to compute the community claim when a spouse makes an investment with separate property, because the separate property capital, not the spouse's efforts, will be the chief contributing factor to any increase in value. See generally J. Thomas Oldham, Separate Property Businesses that Increase in Value During Marriage, 1990 WIS. L. REV. 585. Under Van Camp, the value of the spouse's services is the maximum amount of the community claim. Presumably the value of these services will be small, at least in the normal situation where the spouse devotes little time to separate property investment decisions. In civil law states that have considered the issue, the Van Camp community claim is reduced by rents and profits received from the separate property. Abraham v. Abraham, 87 So.2d 735 (La. 1956); Jensen v. Jensen, 665 S.W.2d 107 (Tex. 1984). "“Civil law states" is the term frequently employed to refer to those states where rents and profits from separate property are community property. See REPPY \& SAMUEL, supra note 1, \$11-1.) In almost all instances, the rents and profits generated by the separate property would exceed the Van Camp claim. Thus, in civil law states it is irrelevant for purposes of this discussion whether an investment decision regarding separate property creates a community Van Camp claim. It would be relevant, of course, in "American rule" states, where rents and profits of separate property remain separate.

406. E.g., Nolan v. Nolan, 486 N.Y.S.2d 415 (N.Y. App. Div. 1985). Professor Andrews is correct that in such a situation an allocation pursuant to "Pereira/Van Camp" would be appropriate. For a discussion of this allocation system, see Oldham, supra note 405, 1990 WIS. L. REV. at 585 . If the spouse devotes all of his or her time to separate property investments, this could be considered a proprietorship business generating community property profits.

407. Thomas R. Andrews, Income From Separate Property: Towards a Theoretical Foundation, 56 Law \& Contemp. Probs 171 (Spring 1993). Professor Andrews' article seems unclear on whether he contends that a community claim should arise from any investment decision during marriage involving separate property. He does state at one point that the community should have a claim when the manager devotes "significant" time to the management of separate property. Id. at 206. If Professor Andrews believes a community claim should arise only in such instances, he and I do not disagree. 
spouse which concerns the community property." 408 The purpose of this provision is unclear. Other provisions already provide to a spouse a right to an accounting. ${ }^{409}$ Normal management restrictions limit a spouse's ability to give away community property without the consent of the other. ${ }^{410}$ Moreover, the language regarding holding the profit as a "trustee" seems somewhat in conflict with other language in the same section suggesting that the managing spouse should not be held to the "prudent person" standard applicable to a trustee. ${ }^{411}$ Professor Reppy has suggested that the statute is intended to encompass a spouse's separate property investments that involve a usurpation of a community opportunity. ${ }^{412}$ Although one needs to strain somewhat to conclude that such an investment is one which "concerns the community property," it certainly is one possible construction. If the section is construed to accept the notion of community opportunity, the courts should limit the scope of such investments to those situations where a manager is certain that a particular investment will be highly profitable. ${ }^{413}$

\section{$\mathrm{V}$ \\ CONCLUSION}

This article has surveyed the manner in which the various community property states regulate the management of community property during an intact marriage. It has endorsed the consensus that sales and encumbrances of community realty should be subject to joint management, as should sales of a community proprietorship business and gifts of more than a reasonable amount of community property. All other community property should be under equal management, other than property for which one spouse has the record title, which should be subject to the title holder's sole management. Also, if the community owns a proprietorship and one spouse manages it, transactions in the ordinary course of business should be subject to that spouse's sole management. The add-a-name remedy is useful for a spouse whose equal management rights are being frustrated by the other spouse.

A spouse should not be liable for negligent management; bad faith is a fairer standard for liability. If a consumption expenditure is grossly excessive, in light of the income, assets, liabilities, and needs of the family, such an expenditure should be considered to have been made in bad faith. Costs stemming from illegal activities may also be considered bad faith losses. If a spouse unilaterally attempts to donate a substantial amount of community property, punitive damages should be possible.

\footnotetext{
408. CAL. Civ. Code ANN. $\$ 5103(b)(3)$ (West 1991).

409. Id. \& 5125.1(b) (West Supp. 1992).

410. See supra notes 239,240 and accompanying text.

411. Cal. Civ. CODE ANN. \& 5103(b).

412. Conversation with Professor Reppy, supra note 198.

413. See supra note $\mathbf{4 0 3}$ and accompanying text.
} 
This discussion has been hampered by the dearth of information that now exists regarding how couples in the United States make management decisions during marriage regarding community property. It would be helpful to know more about their behavior and decisions, as well as whether a substantial number of couples have difficulty establishing a modus vivendi during their marriage regarding how management decisions should be made. Additional empirical evidence would be quite useful.

It is important also to note the fairly obvious gender issues surrounding a number of the matters discussed. Men still manage property in many marriages. Thus, when the issue under discussion is whether the manager should be liable to the other spouse for a certain action, in many instances the inquiry is whether men should be liable to women. This article has attempted to be as "objective" as possible, but complete objectivity is impossible, of course. 